OPEN ACCESS

Edited by:

Ivan Martin,

University of Basel, Switzerland

Reviewed by:

Paul Emile Bourgine,

Lund University, Sweden

Roberto Gramignoli,

Karolinska Institutet (KI), Sweden

*Correspondence:

Lee Ann Applegate

Lee.Laurent-Applegate@chuv.ch

Specialty section:

This article was submitted to

Tissue Engineering and Regenerative

Medicine,

a section of the journal

Frontiers in Bioengineering and

Biotechnology

Received: 30 April 2020

Accepted: 21 August 2020

Published: 23 October 2020

Citation:

Laurent A, Hirt-Burri N,

Scaletta $C$, Michetti M,

de Buys Roessingh AS, Raffoul W

and Applegate LA (2020) Holistic Approach of Swiss Fetal Progenitor

Cell Banking: Optimizing Safe and Sustainable Substrates for Regenerative Medicine and Biotechnology.

Front. Bioeng. Biotechnol. 8:557758. doi: 10.3389/fbioe.2020.557758

\section{Holistic Approach of Swiss Fetal Progenitor Cell Banking: Optimizing Safe and Sustainable Substrates for Regenerative Medicine and Biotechnology}

\author{
Alexis Laurent ${ }^{1,2,3}$, Nathalie Hirt-Burri', Corinne Scaletta ${ }^{1}$, Murielle Michetti ${ }^{1}$, \\ Anthony S. de Buys Roessingh ${ }^{4}$, Wassim Raffoul ${ }^{5}$ and Lee Ann Applegate ${ }^{1,6,7 *}$ \\ ${ }^{1}$ Regenerative Therapy Unit, Lausanne University Hospital, University of Lausanne, Épalinges, Switzerland, ${ }^{2}$ Tec-Pharma \\ SA, Bercher, Switzerland, ${ }^{3}$ LAM Biotechnologies SA, Épalinges, Switzerland, ${ }^{4}$ Children and Adolescent Surgery Service, \\ Lausanne University Hospital, University of Lausanne, Lausanne, Switzerland, ${ }^{5}$ Plastic, Reconstructive and Hand Surgery \\ Service, Lausanne University Hospital, University of Lausanne, Lausanne, Switzerland, ${ }^{6}$ Oxford Suzhou Center for Advanced \\ Research, Science and Technology Co., Ltd., Oxford University, Suzhou, China, ${ }^{7}$ Competence Center for Applied \\ Biotechnology and Molecular Medicine, University of Zurich, Zurich, Switzerland
}

Safety, quality, and regulatory-driven iterative optimization of therapeutic cell source selection has constituted the core developmental bedrock for primary fetal progenitor cell (FPC) therapy in Switzerland throughout three decades. Customized Fetal Transplantation Programs were pragmatically devised as straightforward workflows for tissue procurement, traceability maximization, safety, consistency, and robustness of cultured progeny cellular materials. Whole-cell bioprocessing standardization has provided plethoric insights into the adequate conjugation of modern biotechnological advances with current restraining legislative, ethical, and regulatory frameworks. Pioneer translational advances in cutaneous and musculoskeletal regenerative medicine continuously demonstrate the therapeutic potential of FPCs. Extensive technical and clinical hindsight was gathered by managing pediatric burns and geriatric ulcers in Switzerland. Concomitant industrial transposition of dermal FPC banking, following good manufacturing practices, demonstrated the extensive potential of their therapeutic value. Furthermore, in extenso, exponential revalorization of Swiss FPC technology may be achieved via the renewal of integrative model frameworks. Consideration of both longitudinal and transversal aspects of simultaneous fetal tissue differential processing allows for a better understanding of the quasi-infinite expansion potential within multi-tiered primary FPC banking. Multiple fetal tissues (e.g., skin, cartilage, tendon, muscle, bone, lung) may be simultaneously harvested and processed for adherent cell cultures, establishing a unique model for sustainable therapeutic cellular material supply chains. Here, we integrated fundamental, preclinical, clinical, and industrial developments embodying the scientific advances supported by Swiss FPC banking and we focused on advances made to date for FPCs that may be derived from a single organ donation. A renewed model of single organ donation bioprocessing 
is proposed, achieving sustained standards and potential production of billions of affordable and efficient therapeutic doses. Thereby, the aim is to validate the core therapeutic value proposition, to increase awareness and use of standardized protocols for translational regenerative medicine, potentially impacting millions of patients suffering from cutaneous and musculoskeletal diseases. Alternative applications of FPC banking include biopharmaceutical therapeutic product manufacturing, thereby indirectly and synergistically enhancing the power of modern therapeutic armamentariums. It is hypothesized that a single qualifying fetal organ donation is sufficient to sustain decades of scientific, medical, and industrial developments, as technological optimization and standardization enable high efficiency.

Keywords: biotechnology, cell therapy, clinical cell banking, fetal cell transplantation, primary fetal progenitor cells, regenerative medicine

\section{INTRODUCTION}

\section{Evolution of Regenerative Medicine and Cell Therapies}

Changes in demographics and lifestyle worldwide lead to drastic modifications in the incidence and prevalence of degenerative diseases afflicting the musculoskeletal system and cutaneous structures in general. Accidental trauma continuously yields high numbers of acute clinical cases necessitating considerable therapeutic resources. High demand for efficacious preventive and curative treatments has prompted increasing effort and resource allocation in translational medical research and development. A specific focus area has been the development and implementation of innovative products or protocols designed to optimize biological functions or complement traditional surgical management (Déglise et al., 1987; Vacanti and Langer, 1999; Marks and Gottlieb, 2018). In this context, regenerative medicine currently diversifies into vast arrays of novel therapeutic leads, among which cell therapies and cell-based products represent

Abbreviations: API, active pharmaceutical ingredient; ASC, adipose stem cell; ATMP, advanced therapy medicinal product; BMSC, bone marrow stromal cell; BPyV, bovine polyomavirus; cATMP, combined advanced therapy medicinal product; $\mathrm{CD}$, cluster of differentiation; cGMP, current good manufacturing practices; CHUV, centre hospitalier universitaire vaudois; CMV, cytomegalovirus; DMEM, Dulbecco's modified Eagle medium; DMSO, dimethyl sulfoxide; DNA, deoxyribonucleic acid; EBV, Epstein-Barr virus; ECM, extracellular matrix; EOPCB, end of production cell bank; ePBB, equine progenitor biological bandage; EPC, endothelial progenitor cell; FBS, fetal bovine serum; FPC, fetal progenitor cell; GF, growth factor; GMP, good manufacturing practices; HA, hyaluronic acid; HAV, hepatitis A virus; $\mathrm{HBoV}$, human bocavirus; $\mathrm{HBV}$, hepatitis $\mathrm{B}$ virus; hCMV, human cytomegalovirus; HCV, hepatitis C virus; HSC, hematopoietic stem cell; HE, hematoxylin and eosin; HHV-6/7/8, human herpes viruses types 6, 7 and 8; HIV-1/2, human immunodeficiency viruses types 1 and 2; HLA, human leukocyte antigen; HPL, human platelet lysate; HPV, human papillomavirus; HTLV-1/2, human T-cell leukemia-lymphoma viruses types 1 and 2; HuPyV, human polyomavirus; IB, investigator's brochure; IMPD, investigational medicinal product dossier; iPSC, induced pluripotent stem cell; itMSC, ischemia-tolerant mesenchymal stem cell; KIPyV, KI polyomavirus; LSC, limbal stem cell; MCB, Master Cell Bank; MoA, mechanism of action; mRNA, messenger ribonucleic acid; MSC, mesenchymal stem cell; NSC, neural stem cell; PBB, progenitor biological bandage; PCB, Parental Cell Bank; PCR, polymerase chain reaction; PDT, population doubling time; PDV, population doubling value; PS, penicillinstreptomycin; Px, passage number x; RNA, ribonucleic acid; SV40, simian virus 40; TEM, transmission electron microscopy; TEP, tissue engineering product; WCB, Working Cell Bank; WUPyV, WU polyomavirus. prime prospects. Indeed, such therapies or products, initially proposed over a century ago by Dr. Brown-Séquard and later by Dr. Niehans in Switzerland, constitute multiple potential clinical implementations toward tissue repair optimization and normal organ and system function restoration (Abdel-Sayed et al., 2019b). The reconstitution of maximal patient health can be efficiently implemented through synergistic combinations of tissue engineering, specialized surgical techniques, or classical pharmaco-therapeutic management (Montjovent et al., 2004; Bach et al., 2006; Loebel and Burdick, 2018; Costa-Almeida et al., 2019).

\section{Importance of Standardized Therapeutic Cell Sources}

For classic and novel biological active pharmaceutical ingredients (API), preliminary considerations and prerequisites for biological product development or cell therapy studies reside in the starting materials and cell sourcing. Numerous heterogeneous biological sources have been considered by researchers in human regenerative medicine. Autologous, allogenic, or xenogenic biopsies of various developmental stages may be processed, whereas specific cultured progeny cells retain inherent multifactorial problems to be projected in therapeutic product development processes. Imperative technical, biological, clinical, and sustainability considerations, therefore, help condition and orient cell source selection procedures. Requirements for potential transformation and widespread therapeutic use comprise safety and consistency, availability in adequate quantities, traceable characterization, sufficient inherent expansion capacity, and compatibility with acceptable delivery methods such as engineered bioscaffolds (Doyle and Griffiths, 1998; Monti et al., 2012). Diverse classes of cell sources fit these restrictive criteria, including, but without being limited to, fetal progenitor cells (FPC), embryonic stem cells (ESC), adult stem cells [adipose stem cells (ASC), bone marrow-derived mesenchymal stem cells (BM-MSC), itMSC (ischemia-tolerant mesenchymal stem cells)], neural stem cells (NSC), limbal stem cells (LSC), hematopoietic stem cells (HSC), endothelial progenitor cells (EPC), umbilical cord cells, neonatal foreskin cells, platelets, placenta, and amniotic fluid 
cells (Vertelov et al., 2013; Heathman et al., 2015; Mount et al., 2015; Muraca et al., 2017; Li and Maitz, 2018; Sacchetti et al., 2018; Jayaraj et al., 2019; Torres-Torrillas et al., 2019). Most available cell sources are technically demanding, as progeny cells require dedicated processing or biochemical manipulation to orient or stabilize their potency and self-renewal capacity. Technical limitations related to sub-optimal intrinsic biological parameters significantly hinder the development of therapeutic cellular products. Increased complexity and costs have belated the development or lengthened the pathways for product market approvals (Heathman et al., 2015; Mount et al., 2015). Potential obstacles comprise low cell proliferation potential, the relative scarcity of the source within donors, high phenotypic plasticity or highly variable differentiation potential, tendency to serve as a communicable disease vector, or mediocre in vitro stability and lifespan (Rayment and Williams, 2010; Ratcliffe et al., 2011; Abbasalizadeh and Baharvand, 2013; Heathman et al., 2015; Hunsberger et al., 2015).

\section{Allogenic FPC Technology for Translational Research}

Pragmatic optimization of cell source selection and processing is crucial within translational development and clinical implementation of cell therapies and related products. Iterative amelioration and successful application of standardized workflows have led to identify allogenic primary FPC sources as highly promising and efficient candidates for regenerative medicine (Hebda and Dohar, 1999; De Buys Roessingh et al., 2006; Mirmalek-Sani et al., 2006; Metcalfe and Ferguson, 2007, 2008; Larijani et al., 2015; Grognuz et al., 2016b; Kim et al., 2018). Upon adequate isolation from fetal tissues (i.e., enzymatic or mechanical methods), culture-expansion and cryopreservation, progeny cells and derivatives present numerous advantages. Fetal progenitor cells differentiate until acquiring stable phenotypic (i.e., tissue-specific) characteristics, while retaining intrinsic feeble immunogenic potential, high longitudinal expansion capabilities, and potent stimulatory effects (Quintin et al., 2007; Laurent et al., 2020d). Additionally, such cell types possess few growth requirements to establish an adherent monolayer culture, have high cytocompatibility with various bio-constructs, are resistant to oxidative stress, and have trophic or paracrine mediator effects toward scarless wound healing (Shah et al., 1994; Cass et al., 1997; Doyle and Griffiths, 1998). Furthermore, validation of consistent and robust FPC banking at an efficient industrial scale following good manufacturing practices (GMP) is enabled by continued evaluation of sterility, safety, identity, purity, potency, stability, and efficacy (Quintin et al., 2007). Such prerequisite characteristics defined under restrictive regulations and quality standards for biologicals and starting materials for cell therapies or cell-based products must be investigated rapidly within product development pathways (Doyle and Griffiths, 1998). Allogenic FPC therapies may therefore demonstrably minimize delays in medicinal product availability, as extensive cell banks may serve for direct clinical application or further product developments. Although certain FPCs have yet to demonstrate potential performance advantages when compared to adult cell types in large in vivo settings, clinical insights from the past two decades in our Lausanne Burn Center have outlined the superiority of dermal FPCs versus standard cell therapy products and therapies in use (i.e., autologous platelet-rich plasma, cultured epithelial autografts, cultured dermal-epidermal autografts). Multiple clinical trials in Switzerland and in Asia (i.e., Japan, Taiwan) have confirmed the potential for diversified therapeutic uses of dermal FPCs (e.g., FE002-SK2 cell type) as cell therapies. Additionally, our group has three decades of clinical experience with cell-based cell-free topical formulations (i.e., ovine FPC-based cell-free products) classified as cosmetics or medical devices, which were and are used by clients and patients around the world, with positive feedback related to numerous diversified cutaneous affections.

\section{Translation, Industrial Development, and Commercialization of Swiss FPC Technology}

Cell therapies have been the focus of many public and private sponsors, whereas successful development is highly dependent on interprofessional collaboration integrating all complementary dimensions of novel products and protocols (Marks and Gottlieb, 2018). Allogenic cell-based therapies comprising cell culture steps may be classified as advanced therapy medicinal products (ATMP), and derivatives, as medical devices, whereas using correctly harnessed, consistent, and robust cell sources yields enormous advantages (Applegate et al., 2009; Marks and Gottlieb, 2018). Indeed, fundamental safety and traceability elements are required to prepare investigational medicinal product dossiers (IMPD) and investigator's brochures (IB), whereas optimal biological starting materials may be procured and processed through well-defined Fetal Transplantation Program workflows (Rayment and Williams, 2010; Heathman et al., 2015; Laurent et al., 2020f). Additionally, the robustness of multi-tiered primary FPC biobanks ensures optimal and costeffective manufacturing for processes which require biological material sourcing. Pragmatic devising and implementation of Fetal Transplantation Programs can realistically be achieved in less than six months, with investment costs around a million Swiss Francs (CHF), to establish a GMP parental cell bank (PCB). Assuming total valorization of progeny cellular materials, industrial development efforts may be sustainably equipped for decades and potentially generate trillions of CHF in revenues following a single organ donation. In addition, direct costs of active principles (i.e., viable cells or cell-free extracts) are negligible within market-approval and commercialization steps of standardized bioengineered therapeutic agents. Unique conjunctures of high innovation and local incentives toward industrial development and commercialization of life science products in Western Switzerland (i.e., Health Valley) have led to the development and marketing of Swiss FPC banking and therapeutic/regenerative derivatives in the past decades. Swiss FPC technology is well adapted to tackle regulatory and industrial manufacturing challenges, while safely and effectively supplying arrays of core and adjuvant therapeutic components for highly innovative Swiss-made products globally. Notably, several 
patents and two University Hospital spin-offs (i.e., ELANIX Sàrl and Neocutis SA) have contributed to translational developments or commercialization of tissue engineering products (TEPs) or cosmeceutical products around the world.

\section{Hypothesis Formulation: One-Shot Fetal Transplantation Program}

Optimal management of safety and consistency of therapeutic cell sources is attained by avoiding the pooling of numerous heterogeneous biological samples. Therefore, pragmatic devising and exploitation of Fetal Transplantation Programs present unique characteristics and considerable advantages, outlined throughout two decades of translational research on FPCs in Switzerland. Indeed, ethical and controlled revalorization of a single qualifying therapeutically aborted fetus and donated tissues enables, in a unique way, the differential and simultaneous establishment of multiple primary FPC types (e.g., derived from skin, cartilage, tendon, muscle, lung, bone, connective tissue, intervertebral disc). Furthermore, such transversal conceptual approaches to biobanking have been successfully experimentally validated and iteratively optimized for human, equine, and ovine FPC types in Switzerland (Table 1; Applegate et al., 2013; Laurent et al., 2020b,e). Thereby, each individual and tissue-specific cell source may be selectively applied to complementary cutaneous or musculoskeletal regenerative medicine applications and biotechnological developments. Here, we integrated fundamental, preclinical, clinical, and industrial implementational developments representing the scientific advances supported by multi-tiered FPC banking in Switzerland. Overall, cultured FPCs appear as optimal fits for modern regulatory framework development and stringent GMP industrial transposition in a rapid, safe, effective, and traceable manner (Laurent et al., 2020e,g). The benefit of the Swiss FPC technology described herein is the safe, standardized, ethical, and continual high-value supply chain design for unique diversified biological assets. It is hypothesized that a single qualifying fetal organ donation is sufficient to sustain decades of scientific, medical, and industrial developments, as related technological optimization and standardization enable high efficiency. The range of possible valorization applications levels with the quasiindefinite potential material yield of multi-tiered FPC biobanks. The core therapeutic value of optimized and comprehensive Fetal Transplantation Programs enables sustainable and widespread treatment of millions of patients suffering from cutaneous and musculoskeletal diseases with affordable and effective therapeutic products. The main goal of this work was to substantiate, convey, and broaden awareness and interest around the use of standardized protocols for translational regenerative medicine utilizing FPCs. The renewed transversal and longitudinal model of single organ donation bioprocessing described herein shall continue to provide persistent contributions to modern translational regenerative medicine and biopharmaceutical therapeutic product manufacturing, increasing the power of modern therapeutic armamentariums. An overview of implemented therapies used for managing burns and wounds over the past two decades will be highlighted. In addition, progress on characterization and preclinical work on other tissue-specific FPC types will be reviewed, in order to show parallels in pathways to implement new clinical treatments.

\section{CLASSIC CURRENTS OF THOUGHT: SCARCITY AND POOLING OF THERAPEUTIC CELL SOURCES}

In human organ transplantation, the relative scarcity of high therapeutic value biological materials often requires compromise, while maintaining adequate safety and quality standards (Glantz et al., 2008). In the case of blood banks for medical transfusion or industrial-scale manufacturing of human platelet lysate (HPL) and fetal bovine serum (FBS), pooling of multiple donor samples is necessary to achieve the required lot size to produce coherent deliverable quantities after adequate safety and quality testing is performed. Similarly, production of homogenized cell pools for industrially commercialized therapeutic products (e.g., pooled neonatal foreskin keratinocytes) assumes the integration of many variables and potentially heterogeneous components, albeit meeting the specifications for lot qualification and liberation, achieved due to large numbers of donors. Such practices and related technical considerations are well accepted and detailed in pharmacopeia sections on bloodrelated products, for example. Considerable advantages of focusing efforts on a single donor yielding homogenously derived cell sources enable the abolition of the variability mentioned above, while enabling extensive and rational testing of biological materials. Indeed, screen-testing of donors for pools is then replaced by extensive safety testing of the motherdonor in the Fetal Transplantation Program, followed by routine testing of cell production lots, inherently implemented in GMP workflows, resulting in relatively low overall normalized costs. The consistency, robustness, and extensive cellular expansion capacities within FPC biobanks allow maximal characterization and standardization of biological substrate variables. These crucial aspects were most helpful in the early route to such optimized sources for vaccine or recombinant protein production by the pharmaceutical industry (Applegate et al., 2010). Additionally, optimal conservation and persistence of cellular characteristics throughout whole-cell bioprocessing and maintenance of extensive in vitro lifespans negate the necessity of primary cell immortalization into cell lines, thereby minimizing artificial manipulation of the biological materials (Applegate et al., 2009). Low heterogeneity exists between different fetal organ donations and between different samples consistently processed from the same biopsy (Quintin et al., 2007). Optimal consistency in cellular expansion parameters and endpoint cell yields may be achieved, as FPCs do not rely on growth factor supplementation for phenotypic modulation. A paradigm shift toward the replacement of pooled biological materials by cultured FPCs would surely result in optimized availability and affordability of therapeutic products or biotechnological substrates, while maximizing both consistency and safety, due to the numerous relative advantages of FPC biobanking, as described hereafter. 
TABLE 1 | Overview of primary FPC types established and studied within the Swiss FPC Transplantation Programs, with respective applications and gathered experiences.

\begin{tabular}{|c|c|c|c|}
\hline FPC types & Scope of work and gathered experience & Cell type lifespan characteristics & Selected references \\
\hline $\begin{array}{l}\text { Human dermal FPCs } \\
\text { (e.g., FE002-SK2 cell } \\
\text { type) }\end{array}$ & $\begin{array}{l}\text { The most clinical experience around cutaneous tissue } \\
\text { regeneration has been gathered using such cell types, } \\
\text { effectively applied for managing severe burns, refractory } \\
\text { ulcers, or donor-site wounds. Safety and efficacy of such } \\
\text { therapeutic materials have been demonstrated in various } \\
\text { clinical trials. Thorough experience has been gathered }\end{array}$ & $\begin{array}{l}\text { In preclinical works, FE002-SK2 cells were } \\
\text { studied up to P18-P20 } \\
\text { In clinical settings, FE002-SK2 EOPCBs } \\
\text { were established and validated at P12 } \\
\text { Current clinical protocols describe the use } \\
\text { of cells at P8 }\end{array}$ & $\begin{array}{l}\text { Hohlfeld et al., } 2005 \\
\text { Quintin et al., } 2007 \\
\text { Hirt-Burri et al., } 2011 \\
\text { De Buys Roessingh } \\
\text { et al., } 2015 \\
\text { Laurent et al., 2020e,h }\end{array}$ \\
\hline
\end{tabular}

Human tendon FPCs (e.g., FE002-Ten cell type)

Human cartilage FPCs (e.g., FE002-Cart.Art cell type)

Human bone FPCs (e.g., FE002-Bone cell type)

Human muscle FPCs (e.g., FE002-Mu cell type)

Human intervertebral disc FPCs (e.g., FE002-Disc cell type)

Human lung FPCs (e.g., FE002-Lu cell type)

Ovine FPCs (e.g., AG001-AG005 cell types)
Optimal homogeneity, phenotypic plasticity, and chondrogenic potential have been demonstrated for such cell types, whereas application in caprine models for articular reconstruction has yielded preliminary evidence of safety. Detailed investigation of biochemical and biomechanical parameters of extracellular matrix deposition were performed using such cell types
Detailed investigation of phenotype modulation and matrix production activities were performed on such cell types, providing extensive insights on the multiple parameters within optimization of skeletal tissue engineering. Murine and rat models have demonstrated safety of application of such cell types

High interest for applications in tissue reconstruction was evidenced for such cell types, whereas application in murine models has demonstrated safety and absence of immunogenicity for such cell types

In vitro characterization has allowed to establish the tangible potential of such sources for application in skeletal tissue engineering and amelioration of patient quality of life

Such cell sources were studied and benchmarked with currently used biotechnological cellular substrates (e.g., MRC-5), demonstrating high potential for implementation in industrial workflows with augmented safety, consistency, stability, and output. Therapeutic exploitation of anti-inflammatory properties is considered

Combination of ovine FPC banking and biotechnological processing has demonstrated the potential for stabilization of tremendous healing stimulation properties and application thereof for topical regenerative effects. Extensive in vitro lifespans and high consistency were demonstrated for various primary ovine FPC types, constituting tangible advantages for biological product supply chain sustainability
When using the same isolation and culture methods as described for FPCs, adult dermal fibroblasts are generally characterized by a lifespan of 6-7 passages In preclinical works, FE002-Ten cells were characterized by a lifespan of 12-15 passages

Recommended passages for therapeutic applications are P6 (cell therapies) to P8 (cell-based cell-free formulations) When using the same isolation and culture methods as described for FPCs, adult tenocytes are generally characterized by a lifespan of 7-8 passages In preclinical works, FE002-Cart.Art cells were characterized by a lifespan of 10-12 passages, whereas optimal functionality (i.e., ECM generation) was confirmed up to P5

Recommended passages for therapeutic applications are P5 (cell therapies) to P8 (cell-based cell-free formulations) When using the same isolation and culture methods as described for FPCs, adult chondrocytes are generally characterized by a lifespan of 6-8 passages In preclinical works, bone FPCs were studied up to P8-P9

Recommended passages for therapeutic applications are P5 (cell therapies) to P7 (cell-based cell-free formulations)

In preclinical works, muscle FPCs were studied up to P4-P5

In preclinical works, intervertebral disc FPCs were studied up to P4-P6

In preclinical works, FE002-Lu cells were studied up to P20

In preclinical works, ovine FPCs were studied up to P40
Quintin et al., 2009, 2010

Grognuz et al., 2016a,b Aeberhard et al., 2019 Grognuz et al., 2019

Quintin et al., 2010 Darwiche et al., 2012 Broguiere et al., 2016 Studer et al., 2017 Cavalli et al., 2018 Li et al., 2020

Montjovent et al., 2004, 2007, 2008, 2009 Hausherr et al., 2017, 2018

Hirt-Burri et al., 2008a Laurent et al., 2020c

NA

Lapp et al., 2013

(Continued) 
TABLE 1 | Continued

\begin{tabular}{|c|c|c|c|}
\hline FPC types & Scope of work and gathered experience & Cell type lifespan characteristics & Selected references \\
\hline $\begin{array}{l}\text { Equine FPCs (e.g., } \\
\text { ED001-ED002 cell } \\
\text { types) }\end{array}$ & $\begin{array}{l}\text { The simultaneous multi-organ harvest workflow adopted } \\
\text { for human fetal donations was conceptually confirmed } \\
\text { and experimentally validated using equine fetal tissues. } \\
\text { Subsequent characterization and therapeutic applications } \\
\text { of equine FPC therapies have demonstrated high } \\
\text { similarities with human regenerative medicine and further } \\
\text { broaden the potential therapeutic applications of primary } \\
\text { FPC banking }\end{array}$ & $\begin{array}{l}\text { In preclinical works, equine FPCs were } \\
\text { studied up to P10 }\end{array}$ & Laurent et al., 2020b \\
\hline
\end{tabular}

Specific cell type lifespan characteristics were included, expressed as passages (see Supplementary Material). Data succinctly summarize primary and secondary published works, for which selected references are provided. Due to the renewal of regulatory frameworks and successive adaptations of the Transplantation Programs

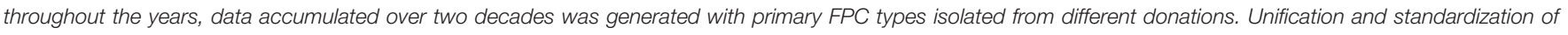
FPC clinical use was operated after processing of the FE002 fetal donation in 2009. The overarching conclusions are the high consistency, extensive banking potential, and proven safety of various primary FPC types of mammalian origin. NA, Non-Applicable.

\section{SWISS FETAL TRANSPLANTATION PROGRAMS}

Usefulness and adequacy of Fetal Transplantation Programs are most easily demonstrable, and the utilization of robust FPC banks may contribute to the alleviation of the constant organ transplant demand or shortages. The practical design of optimal workflows for cell source selection and processing is paramount when developing cell therapy, tissue bioengineering, or cellbased products. Along with biological material homogeneity, consistency, and robustness, documented traceability and quality also ensure safety and efficacy for clinical applications (Kent and Pfeffer, 2006; Pfeffer and Kent, 2006). Optimization must, therefore, be undertaken for the identification of cell sources, material procurement, and subsequent processing. Transplantation Programs are highly regulated and adaptable frameworks optimally suited for such exhaustive and descriptive activities. Swiss FPC Transplantation Programs were devised in the early 1990s in Lausanne to establish cell banking of primary FPC types after regulated voluntary pregnancy terminations and subsequent organ donations (Applegate et al., 2013). Initially registered in 1991 and reorganized in 2007, the successive Transplantation Programs remain regulated by Swiss federal laws, pertaining to organ transplant procedures, and are registered with the Swiss National therapeutic products agency (i.e., Swissmedic, Bern, Switzerland). Key stakeholders in the Program collaboratively pool complementary professional expertise and capabilities to fulfill respective duties and ensure adequate compartmentalization (Figure 1). Adequate documentation enables appropriate Program validation and follow-up, comprising technical specifications, fetal biobank regulations, and mandatory license documents. Highly regulated and sequentially defined voluntary and therapeutic pregnancy interruptions serve as the operating base for mother-donor recruitment. Regulatory vetting and GMP constraints relative to traceable tissue procurement, testing, and bioprocessing favor an up-stream medical and serological testing approach (i.e., repeated bloodwork for HIV-1/2, HTLV-1/2, hCMV, EBV, HHV-6/7/8, HSV, HBV, HCV, HPV, West Nile virus, syphilis) of motherdonors for inclusion in the Program, positively impacting longterm testing costs (Supplementary Figure 1; Quintin et al., 2007;
Applegate et al., 2013). Practically, optimized workflows and specifications eventually enabled traceable simultaneous isolation of various FPC types (i.e., FPCs isolated from fetal tissues such as skin, cartilage, tendon, bone, muscle, intervertebral disc, lung) from a single fetal organ donation (i.e., codename FE002, 2009) for rapid and efficient PCB establishment and subsequent industrial GMP processing (Laurent et al., 2020e). Specific bioprocessing methodologies enable safe and sustained use of original cell sources for extended periods, as adequate testing implementation ensures maximal safety of the end-products or substrates (De Buys Roessingh et al., 2015). One single qualifying fetal organ donation, yielding specific tissue biopsies, is sufficient for the derivation of multi-tiered cryopreserved cell stocks, which may be preserved for decades, minimizing the need for multiple organ donations, ultimately lowering constraint levels related to timeframes and costs.

\section{PRIMARY FPCS: STRONG SCIENTIFIC AND MEDICAL INNOVATION BACKGROUND}

\section{Historical Use of FPCs or Embryonic Cell Types and Cell Lines}

Fetal and embryonic cells have been extensively used throughout history in the biomedical industry, starting back in the 1930s with the continuous development of numerous vaccines (e.g., chickenpox, Ebola, hepatitis A, HIV, influenza, Japanese encephalitis, polio, rabies, rubella, and smallpox), which are still currently in use (Jacobs et al., 1970; Reisinger et al., 2009; Applegate et al., 2013, 2017). A Nobel Prize in medicine was given in 1954 for the polio vaccine, developed using human fetal cell cultures. Such industrial uses demonstrate the quasi-universal applicability of fetal cells as substrates in therapeutic product manufacturing, providing excellent in-use safety and stability (Hayflick et al., 1962; Jacobs et al., 1970; Zimmerman, 2004; Olshansky and Hayflick, 2017). Specific human embryonic/fetal tissues and/or animal biopsies led to the establishment of well-known cell types or cell lines (e.g., HEK-293, MDCK, MRC-5, PER.C6, and WI-38/CCL-75) (Palache et al., 1997; 


\section{FETAL TRANSPLANTATION PROGRAM ORGANIGRAM}

\section{Fetal Transplantation Program Manager}

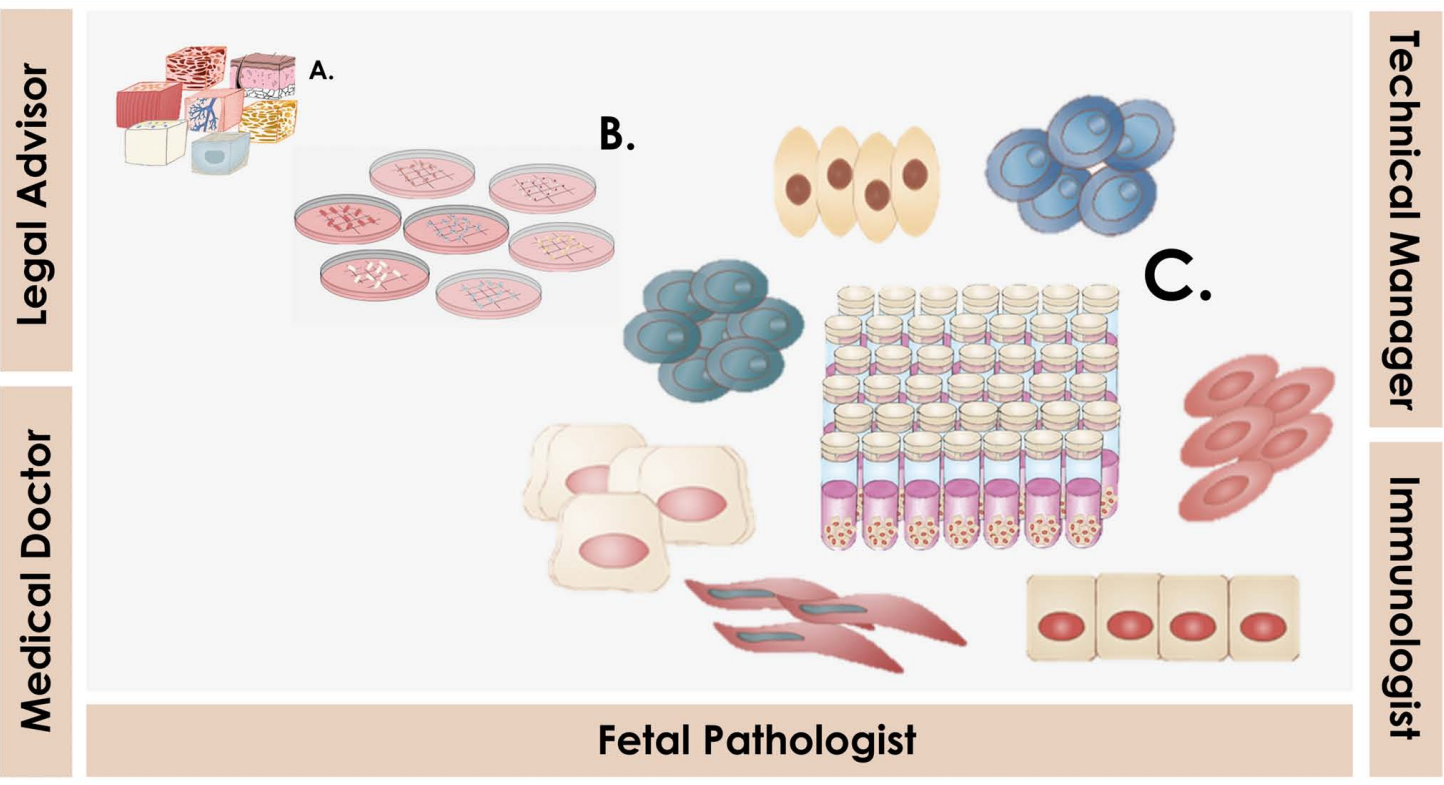

\section{THERAPEUTIC FPC USES}

- Tissue engineering

- Reconstructive surgery

- Human / Veterinary

- Allogenic / Xenogenic

- Acute lesions (e.g., burns, wounds)

- Chronic lesions (e.g., ulcers)

\section{FPC PRODUCT POTENTIAL}

- Cell therapies (TEP / ATMP)

- Medical devices (Class I to III)

- Substrates (e.g., vaccines, feeder-layers)

- Development (e.g., cellular models, screening)

FIGURE 1 | Schematic overview of the components and ramifications of a Fetal Transplantation Program and of primary FPC banking in general, assorted to potential applications and benefits in view of product development. The high core-value is created throughout adequate biopsy procurement, bioprocessing thereof, and establishment of homogenous PCBs of primary FPC types. Essential multidisciplinary building blocks of a human Fetal Transplantation Program comprise complementary expertise and experience, mutualized between the Program Manager (i.e., establishment and coordination of the Program, usually a pharmacist or biologist with extensive experience in tissue processing and cell banking for optimized cell source selection and technical specifications establishment), the Legal Advisor (i.e., interpretation of regulatory frameworks for transplantation practice and therapeutic product use, design and validation of the Program within local and national laws, and regulations on research and medicine), the Technical Manager (i.e., oversight of the bioprocessing and cell banking steps, usually a biologist or senior laboratory technician with extensive experience in tissue processing and cell banking), the Medical Doctor (i.e., experienced gynecologist, performs donor identification, screening, consent obtention, and donation procurement, preferably from a secondary independent hospital), the Fetal Pathologist (i.e., oversight of coded autopsy, preferably experienced in fetal histopathology), and the Immunologist (i.e., pathogen screening of mother-donor biological samples and of established cell banks). A defined organigram enables optimal anonymous traceability within the information flow. Iterative validation steps ensure optimal quality and safety of all processed materials. Pathology and serology reports are evaluated to confirm requirement fulfillment and admissibility of the donor in the Program. Established PCBs are quarantined until the three-month bloodwork results exclude seroconversion of the donor for the target pathogens. Potential applications of banked FPC types are diverse, comprising cell therapy or medical device development for arrays of soft-tissue and musculoskeletal acute and chronic affections (i.e., human and veterinary), in vitro fundamental research, and industrial biotechnological manufacturing processes (e.g., viral vaccine production, feeder-layer roles). 
Zimmerman,2004). Early therapeutic use of fetal tissue or derived FPCs focused on neurology (e.g., Huntington's or Parkinson's disease, strokes, spinal cord injuries) (Freeman, 1997; Clarkson, 2001; Rosser and Dunnett, 2003; Reier, 2004; Savitz et al., 2004). Fetal hepatic cells were studied and transplanted to manage severe hematological disorders, immunodeficiencies, liver failure, diabetes, and congenital metabolic disorders (Touraine et al., 1993; Gridelli et al., 2012; Montanucci et al., 2013; Cardinale et al., 2014). In clinical settings, fetal hepatocyte infusions have been performed in more than 30 patients so far in view of alleviating transplant shortages, with promising results yielded mostly by one research group in India (Habibullah et al., 1994; Khan et al., 2010).

\section{Specific Characteristics and Therapeutic Potential of FPCs}

Fetal wound healing before mid-gestational stages is specifically and characteristically orchestrated, leading to regeneration without scar tissue formation in several organs and structures (e.g., skin, bone, cartilage, tendon) (Adzick and Longaker, 1992; Longaker et al., 1992; Namba et al., 1998; Beredjiklian et al., 2003; Bullard et al., 2003; Dang et al., 2003; Favata et al., 2006; Rodrigues et al., 2019). Cultured FPCs isolated after nine weeks of gestation are pre-terminally differentiated, possessing finite high expansion capacities, and scarless regeneration stimulation potentials, while presenting low risks of immunogenicity or tumorigenicity after transplantation (Figure 2; Doyle and Griffiths, 1998; Quintin et al., 2007; Markeson et al., 2015; Laurent et al., 2020d). Differential gene expression (e.g., genes coding for TGF- $\beta 2$, BMP-6, GDF-10, midkine, or pleiotrophin) and related proteomic fingerprints may explain specific healing patterns mediated by adult cells and FPCs (Hirt-Burri et al., 2008b). As early descendants of stem cells, FPCs are found in diverse developed tissues (e.g., skin, intestine, blood system, brain), mediating tissue homeostasis and repair (Nakatomi et al., 2002). Along with the absence of self-renewal capacity, relatively restricted potency distinguishes FPCs and stem cells, as FPCs are reportedly unipotent or oligopotent, providing relatively superior phenotypic stability. Technically, FPCs are independent of growth factor supplementation or presence of cellular feederlayers for in vitro cultures (Asahara et al., 1997; Seaberg and van der Kooy, 2003). This specific inherent advantage over undifferentiated MSCs or induced pluripotent stem cells (iPSC) primarily benefits consistency in manufacturing and industrial scale-up processes (Doyle and Griffiths, 1998; Ramelet et al., 2009; Zuliani et al., 2013; Tan et al., 2014; Lee et al., 2020). Constraints on production timelines and economic factors additionally favor the use of low-maintenance and robust cell types such as primary FPCs.

\section{Immune Privileges of FPCs}

Fetal progenitor cells are pre-immunocompetent and fail in eliciting immunological responses due to the lack of post-thymic T-lymphocytes in the first 13 gestational weeks (Gabbianelli et al., 1990; Crombleholme et al., 1991). Major histo-compatibility complex (MHC) antigen expression during fetal development is organ- and gestational age-specific (Foglia et al., 1986). Primary FPCs generally lack MHC class II proteins (e.g., HLA-DP, DQ, $\mathrm{DR}$ ) and exhibit relatively low levels of $\mathrm{MHC}$ class I counterparts (e.g., HLA-A, B, C), approaching cell surface marker panels characterizing MSCs or neonatal foreskin keratinocytes, for example (Tsujisaki et al., 1987; Streit and Braathen, 2000; Le Blanc et al., 2003; Grognuz et al., 2016b). Specific fetal tissues were shown to express HLA-G, a known mediator of tolerogenic effects (Piccinni, 2010; Deschaseaux et al., 2011). Fetal progenitor cells therefore evade immune responses, possibly through immunemodulation and inhibition of $\mathrm{TCD}^{+}$lymphocyte proliferation (Bartholomew et al., 2002; Le Blanc et al., 2003). Absence during normal human gestation of an immune reaction, despite in utero recognition of paternal HLA-C markers and modulatory effects of HLA-G on lymphocytic activity, additionally characterize the particular immune status of fetal tissues and FPCs (Rouas-Freiss et al., 1997; Ober, 1998; Carosella et al., 2008; Piccinni, 2010).

\section{Technical Simplicity, Stability, and Robustness of FPCs}

The ability of therapeutic cells to maintain inherent biological characteristics, when isolated in vitro, presents considerable potential for tissue engineering. Differential requirements for processing and clinical delivery specifically characterize ESCs, adult MSCs, and FPCs, whereas numerous technical advantages favor the use of the latter (Bhattacharya, 2004; Ostrer et al., 2006; Capes-Davis et al., 2010). Embryonic stem cells can be derived from the blastocyte (i.e., constituted by approximately 100 cells) between zero and two weeks after ovum fertilization. These "immortal" cells require growth factor support in culture or appropriate feeder-layers to sustain growth, potentially introducing inconsistencies in progeny cell populations. Additionally, ethical concerns, propensity toward tumorigenicity, and high potency render the obtention and use of such populations difficult. Embryonic fetal cells can be derived at timepoints between five and eight weeks of gestation (i.e., total size of $>10^{3}$ cells/embryo). Relatively restricted potency compared to ESCs characterizes these populations, but all other disadvantages remain, assorted to onerous culture and maintenance requirements. Fetal tissues (i.e., total size of $>10^{6}$ cell/fetus) exist in the developing organism between weeks number nine and sixteen of the gestational period. Fetal progenitor cells yielded by various fetal tissues are therefore pre-terminally differentiated and present defined tissue-specific properties and behaviors, which are conserved in monolayer in vitro cultures. In contrast, MSCs are scarce or difficult to isolate and to purify for obtention of adequate cell populations, are patient-specific because of immunological and safety factors, and therefore necessitate multiple organ donations, whereas culture scale-up is difficult to implement. Legal distinctions categorize work around cellular material existing before and up to eight weeks of gestation, as a federal license is required in Switzerland. Starting at nine weeks of gestation, studies with specific fetal tissue biopsies are regulated under Federal Transplantation Laws, and such tissues are defined as organ donations. Standardized isolation methods for FPCs in defined gestational timeframes 


\section{ALLOGENIC FETAL PROGENITOR CELLS : BIOLOGICAL AND TECHNOLOGICAL ADVANTAGES}

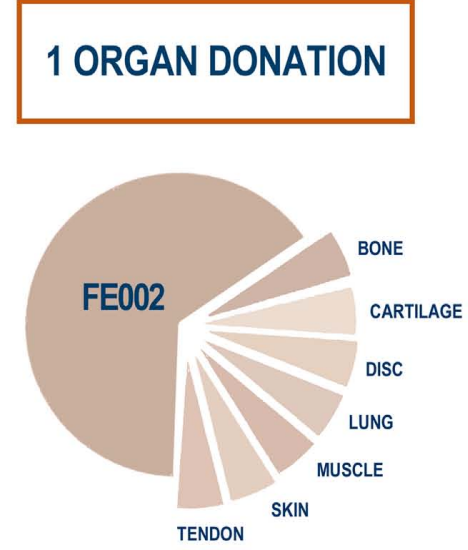

\begin{tabular}{l} 
FPCs: GENERAL \\
\hline ADVANTAGES \\
Extensive donor screening \\
Safety and consistency \\
No growth \\
factors/supplements \\
Rapid proliferation \\
Extensive cell banks \\
Thorough testing \\
On-demand availability \\
High biocompatibility \\
Lowimmunogenicity
\end{tabular}

\section{FPCs: CELL TYPE CHARACTERISTICS}

Tissue-specific cells

Extensive in vitro lifespan

Robust cell populations

Defined markerpanel

Stable karyotype

Stable phenotype

Stimulation of adult

cells

Universal cell stock

\section{FPCs: THERAPEUTIC CELL MOA}

Cell-cell contact

Apoptosis reversal

Microvesicle release

Matrix deposition

Paracrine/trophic modulation

- Inflammation $\downarrow$

- Proliferation $\uparrow$

- Migration $\uparrow$

- Angiogenisis $\uparrow$

- Differentiation $\uparrow$

\section{EXIENSIVE TESTING For QUALIY/SAFETY-MANUFACTURING CONTINUUM}

\begin{tabular}{|c|c|c|c|c|c|}
\hline DOI & FPC PCB & FPC MCB & FPC WCB & FPC ЕОРCB & PRODUCT \\
\hline $\begin{array}{l}\text { - Health } \\
\text { assessment } \\
\text { - Repeated } \\
\text { bloodwork }\end{array}$ & $\begin{array}{l}\text { - Screening } \\
\text { - Testing } \\
\text { - Validation }\end{array}$ & $\begin{array}{l}\text { - Testing } \\
\text { - Validation } \\
\text { - Release }\end{array}$ & $\begin{array}{l}\text { - Testing } \\
\text { - Validation } \\
\text { - Release }\end{array}$ & $\begin{array}{l}\text { - Safety } \\
\text { screening } \\
\text { - Testing } \\
\text { - Validation }\end{array}$ & $\begin{array}{l}\text { - Quality } \\
\text { control } \\
\text { testing } \\
\text { - Release }\end{array}$ \\
\hline
\end{tabular}

FIGURE 2 | Summary of biological and technological advantages of processing and using FPCs as therapeutic agents, production intermediates, or substrates, From one single fetal organ donation (i.e., FE002, 2009), various tissue samples (e.g., bone, cartilage, intervertebral disc, lung, muscle, skin, tendon) were bioprocessed for FPC isolation using both enzymatic and non-enzymatic methods. Inherent technical and clinical advantages are attributed to FPCs. Various proposed mechanisms of action (MoA) of allogenic FPCs are summarized. Optimized and consistent tissue procurement, cell isolation, and biobanking workflows allow for thorough testing throughout the manufacturing continuum, ensuring quality and safety of end-products.

yield uniform preliminary cultured populations characterized by homogenous and stable tissue-specific properties, without the need for specific cell-sorting (Figures 2-5 and Supplementary Figures 2-7; Quintin et al., 2007, 2009, 2010). Progeny FPCs are characterized by their relatively high and consistent division potential in vitro before reaching senescence due to their relatively longer telomeres (Decary et al., 1997). Therapeutic applications in clinical protocols or product manufacturing workflows in regenerative medicine restrict the use of progeny cell sub-cultures to two thirds of the documented and safetyvalidated in vitro lifespans of specific cell types. Such regulations ensure end-product consistency and maintenance of paramount cellular biological properties, such as cumulative or specific protein content (e.g., MDK, MMP, TGF, TIMP, and VEGF levels), gene expression levels, and bio-stimulatory activities to be assessed via quantitative quality controls or functional assays (Vuadens et al., 2003; Quintin et al., 2007). A benefit of using allogenic banked cellular substrates instead of autologous sources is the drastic reduction in availability delays, as off-the-freezer cell therapies or stabilized cell-derivatives may be available upon request. Maximized safety and quality of end-products are demonstrable with banked FPCs, allowing realistic clinical translation, transposition to industrial settings, and commercial implementation in leading markets, well within current regulatory frameworks and sustainable developmental economic burdens (Quintin et al., 2007; Larijani et al., 2015; Marks and Gottlieb, 2018).

\section{Swiss Multi-Tiered Biobanking Model for Primary FPCs}

Optimal stability and consistency of FPCs derived from one single organ donation present a vast potential toward scalable and extensive biobanking, while following stringent safety- and quality-driven regulations for therapeutic product manufacturing (Abbasalizadeh and Baharvand, 2013; Hunsberger et al., 2015; Laurent et al., 2020e,g). Albeit finite, in vitro lifespans and expansion potentials of primary 

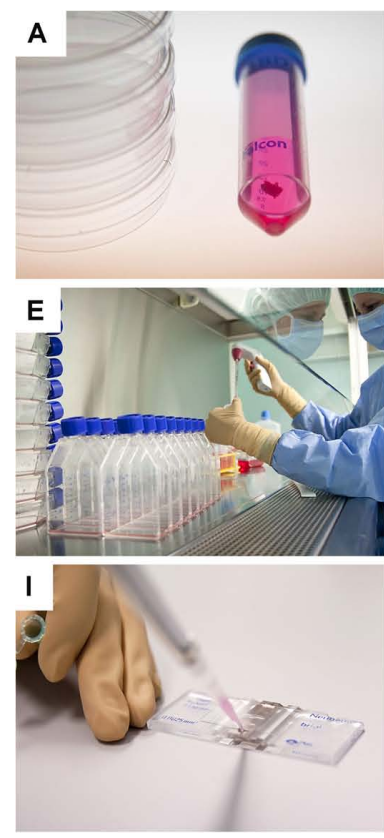
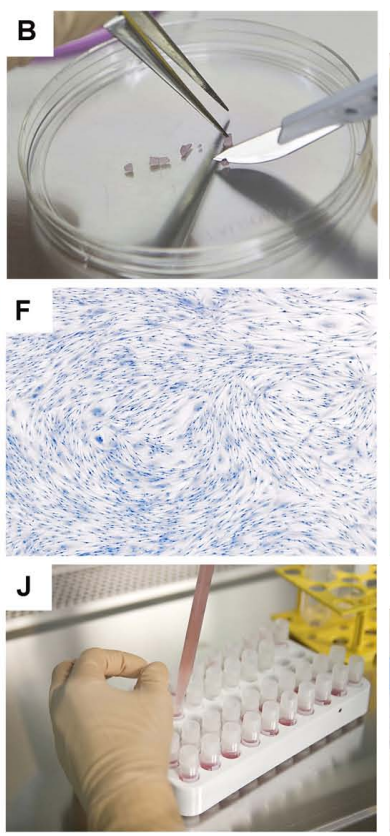
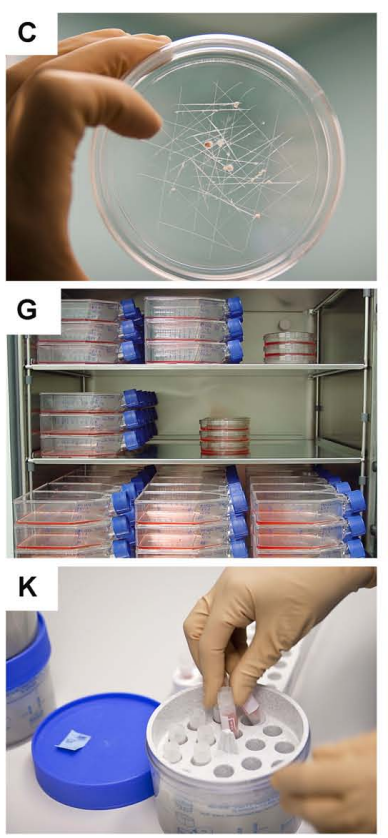
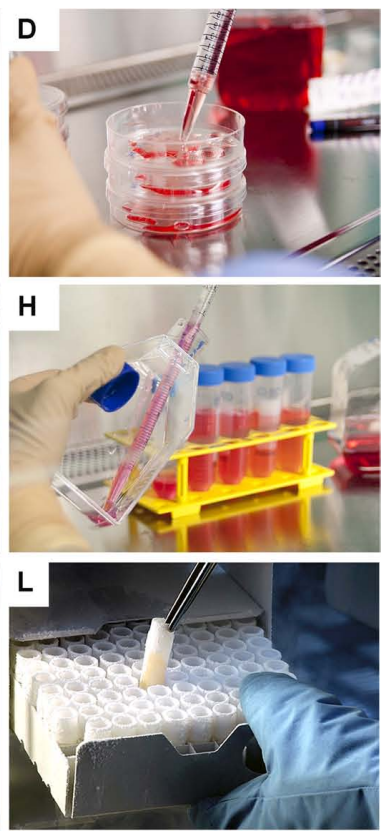

FIGURE 3 | Overview of the simple and standardized mechanical procedure for primary FPC type isolation from organ donation tissue biopsies and Parental Cell Bank establishment. Highly similar simultaneous processing of multiple tissues yielded by one organ donation enables maximal consistency throughout progeny cell populations. (A) Individual anonymized tissue biopsies are provided by the pathology department in transport medium. Each specific tissue of interest is separately conditioned. Fetal skin is used as an example herein. (B) Tissue biopsies are further processed into small fragments. (C) Tissue fragments are minced and placed within a checkboard pattern created on the culture surface by scoring with a sterile scalpel. (D) Cultures are initially fed with small amounts of growth medium in order to avoid early flotation of fragments. (E) Adherent cells are further expanded in culture flasks. (F) Cells are regularly microscopically assessed to verify adequate morphology or growth and to exclude contamination. (G) Multiple FPC types are simultaneously culture-expanded in humidified incubators set at $37^{\circ} \mathrm{C}$ under $80 \%$ relative humidity and $5 \% \mathrm{CO}_{2}$. (H) Confluent cells are harvested by trypsin detachment and pooled. (I) Total and viable relative cell counts are determined by microscopic enumeration using Trypan blue exclusion dye. (J) Cells are resuspended in a cryopreservation solution (i.e., DMEM, FBS, DMSO) and homogenously dispensed in individual cryovials (i.e., $10^{6}-10^{7}$ viable cells/vial). (K) Vials are transferred to controlled-rate freezing devices (e.g., Mr. Frosty ${ }^{T M}$ or CoolCells ${ }^{\circledR}$ ) and placed in ultra-low temperature freezers (i.e., $-80^{\circ} \mathrm{C}$ ) overnight. (L) Cryovials are then transferred to Dewar storage tanks in the gaseous phase of liquid nitrogen for long-term storage. Some technical limitations in large-scale cell bank manufacturing are outlined and must be the object of continuous optimization. Such limits comprise, without being limited to, operator-related cell quantification, relatively important occupied volumes in conventional incubators with limited airflow and oxygenation, or relative contamination risks (e.g., open vessels for cryopreservation).

FPCs are sufficient for industrial-scale GMP manufacturing with minimal processing requirements. Standardized multi-tiered cell banking model establishment (i.e., sub-tiering cryopreserved cell stocks in Parental, Master, Working, and End of Production Cell Banks, PCB-MCB-WCB-EOPCB, with tier nomenclature based on in vitro passages) allows for efficient constitution, transposition, and utilization of consistent biological sources of high therapeutic value (Figures 6, 7; De Buys Roessingh et al., 2013; Laurent et al., 2020e). Rapid establishment of such cryopreserved materials allows for quasi-infinite research and development, as each FPC type from the original organ donation may be valorized to provide $>10^{7}-10^{9}$ product doses. Local applications (e.g., skin, tendon, or cartilage tissue repair) of relatively small doses of cells or derivative equivalents (i.e., $5 \times 10^{5}-10^{6}$ units, cell type-specific) are optimal and preferable to systemic delivery, as they allow sparing use of biological materials, compared to alternative therapeutic cell sources (e.g., $10^{8}$ cells/dose for MSCs or $10^{9}$ cells/dose for pluripotent stem cells) (Hohlfeld et al., 2005; Pigeau et al., 2018; Pittenger et al., 2019). At the same time, safety testing and quality controls are easily implemented throughout bioprocessing workflows
(Figure 8; Quintin et al., 2007). Derivation of multiple FPC types from a single organ donation and the development of robust analytical technologies drastically simplify screening and testing processes during manufacturing (e.g., tests for sterility, isoenzyme typing, mycoplasma, viruses, prions, endotoxins, virus-like particles, retroviral activity, fungi, yeasts, bacteria, and tumorigenesis assays) (Applegate et al., 2009). Maximized safety, efficiency, and optimized industrial manufacturing schemes cost-enable innovative therapeutic developmental research and ensure on-demand availability of end-products (Haack-Sørensen and Kastrup, 2011; Abbasalizadeh et al., 2017; Pigeau et al., 2018; Hunt, 2019).

\section{Human Dermal FPCs (e.g., FE002-SK1, FE002-SK2 Cell Types)}

Cell Therapies for Cutaneous Regenerative Medicine

Sub-optimal pharmacotherapeutic management of severe and complex cutaneous affections and complications (e.g., chronic ulcers, burns, donor-site wounds) has prompted the development of numerous skin graft solutions (e.g., amniotic membrane, 

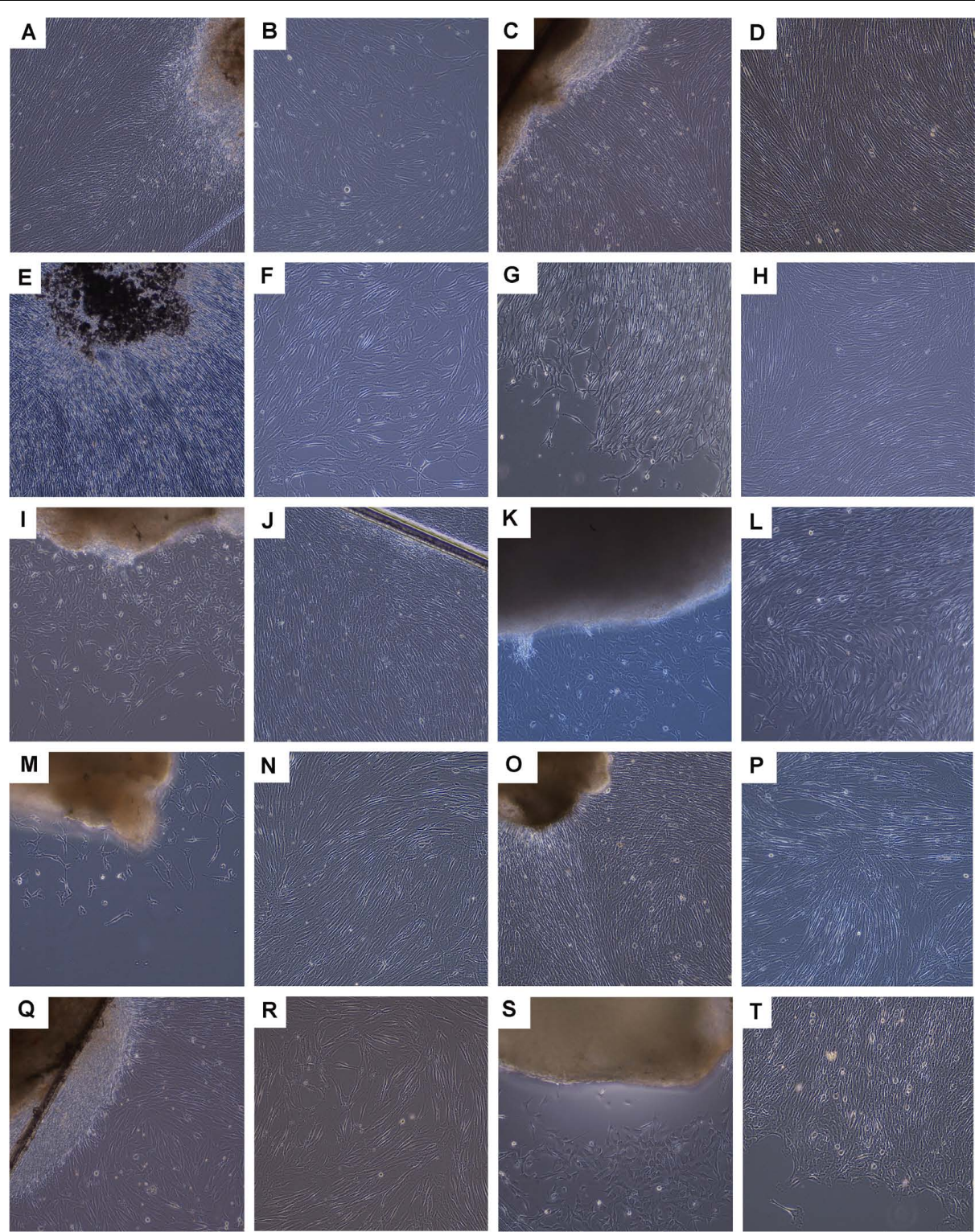

FIGURE 4 | Photographic imaging of culture initiation and culture-expansion steps performed following a fetal organ donation within updated legislative frameworks (i.e., post-2007). Various tissue biopsies were procured from the same organ donation (i.e., FE002, 2009) and simultaneously differentially processed following enzymatic and non-enzymatic methodologies. Pictures were obtained under 100X optical magnification on a phase contrast microscope and represent the non-enzymatically isolated primary FPC types. (A,B) Ventral skin with emitting dermal FPCs (i.e., FE002-SK1 cell type, P0). (C,D) Dorsal skin with emitting dermal FPCs (i.e., FE002-SK2 cell type, P0) and confluent cells at P2. (E,F) Tendon tissue with emitting tendon FPCs (i.e., FE002-Ten cell type, P0). (G,H) Articular cartilage with emitting cartilage FPCs (i.e., FE002-Cart.Art cell type, P0) and confluent cells at P2. (I,J) Cartilage tissue with emitting cartilage FPCs (i.e., FE002-Cart cell type, PO). (K,L) Bone tissue with emitting bone FPCs (i.e., FE002-Bone cell type, P0). (M,N) Intervertebral disc tissue with emitting disc FPCs (i.e., FE002-Disc cell type, P0) and confluent cells at P1. (O,P) Lung tissue with emitting lung FPCs (i.e., FE002-Lu cell type, P0) and confluent cells at P1. (Q,R) Muscle tissue with emitting muscle FPCs (i.e., FE002-Mu cell type, P0) and expanding cells at P2. (S,T) Connective tissue with emitting connective tissue FPCs (i.e., FE002-CT cell type, P0). For higher magnification, see Supplementary Figure S5.

cadaver grafts, fish skin), innovative bioengineered cellular therapy solutions (e.g., cultured autografts), or autologous and allogenic cell-based products (e.g., Allox ${ }^{\circledR}$, Apligraf ${ }^{\circledR}$, Epicel $^{\circledR}$, Lyphoderm $^{\circledR}$, OrCel ${ }^{\circledR}, \mathrm{ReCell}^{\circledR}$, TransCyte ${ }^{\mathrm{TM}}$ ) that complement surgical care and support tissue structural integrity and functional recovery (Lukish et al., 2001; Limat and Hunziker, 2002; Kumar et al., 2004; Amani et al., 2006;
Hartmann et al., 2007; Zaulyanov and Kirsner, 2007; Akita et al., 2008; Hirt-Burri et al., 2008b; Guerid et al., 2013; Zuliani et al., 2013; Malhotra and Jain, 2014; Tan et al., 2014; Debels et al., 2015; Akershoek et al., 2016; Abdel-Sayed et al., 2019b; Lima-Junior et al., 2019; Momeni et al., 2019; Climov et al., 2020). Further optimization of biological starting materials for such advanced solutions may primarily benefit 


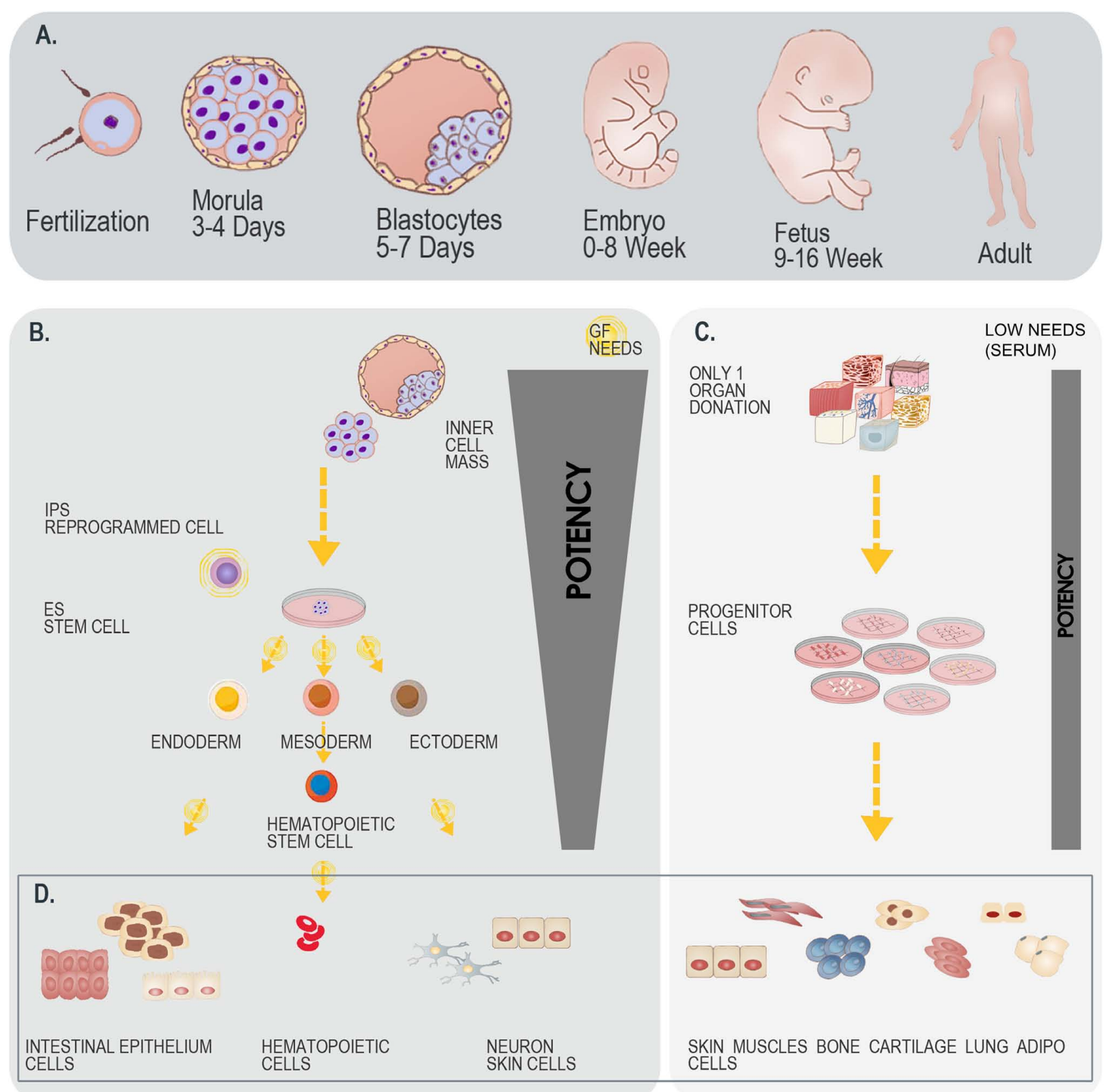

FIGURE 5 | Differential overview highlighting the similarities and differences between stem cells and primary FPC types. (A) Schematic representation of developmental stages within the human biological continuum, assorted to classes of cells to potentially be isolated. (B) Schematic representation of the isolation and culture-expansion of stem cells from blastocytes. Such cell types may serve for subsequent processing and generation of various stem cell types (e.g., iPSCs). (C) Schematic representation of the simultaneous isolation and culture-expansion of primary FPCs. Such procedures are relatively simpler and more robust than when working with stem cells, as a single organ donation enables differential isolation of several tissue-specific cell types, without the resort to growth factor (GF) cocktails in culture-expansion and maintenance steps, which largely and positively impact the consistency of progeny cellular materials. (D) Schematic representation of cellular materials obtained after biopsy processing and cell bank establishment. Differentiated cell types are eventually obtained when using both starting materials (i.e., blastocytes versus fetal tissue organ donations), with specificities to each strategy. A single isolation procedure is necessary when working with blastocytes, whereas differential biochemical manipulation enables generation of various cellular phenotypes maintaining designed relatively restricted potency. A single isolation procedure is equally necessary when working with fetal tissues, whereas standardized parallel processing enables generation of homogenous FPC types, inherently relatively restricted in terms of potency. Overall, while both strategies for therapeutic cell type obtention may be compared, the use of primary FPCs is relatively more robust, may be standardized, is cost-effective and sustainable.

from banked dermal FPCs (e.g., FE002-SK2 cell type), which have displayed clinical benefits in topically managing complex dermatological conditions, such as actinic dermatitis, eczema, or psoriasis. Cell-laden bioengineered constructs and cell-derivative formulations using dermal FPCs present potent therapeutic results (Hirt-Burri et al., 2011; Moore et al., 2018; Lorant et al., 2019; Poinas et al., 2019). Adapted pharmaceutical forms and delivery scaffolds are moldable and biocompatible with wounded tissues and therapeutic cells, providing optimal physical characteristics (e.g., porosity and mechanical stability). These scaffolds also allow the development of cell contraction forces and homogenous distribution of therapeutic biological substrates. Possible matrices comprise nylon mesh, silicone, collagen (i.e., bovine, equine, or porcine), polyglycolic acid, or hyaluronic 


\section{FE002 SPECIFIC TISSUE BIOPROCESSING AND CELLLISOLATION}

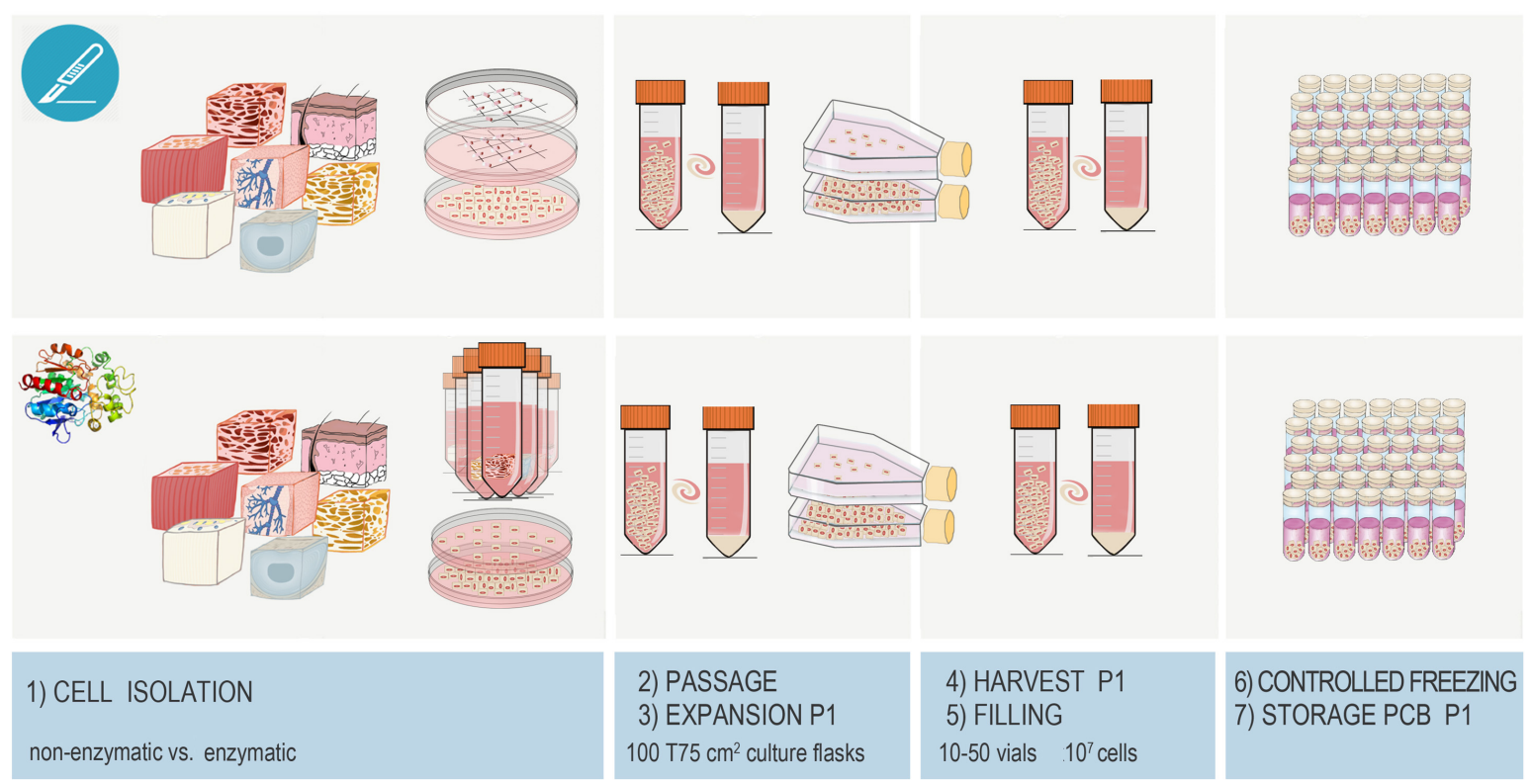

FIGURE 6 | Overview of the simultaneous differential biopsy processing methods devised for the FE002 fetal organ donation in view of adherent FPC culture initiation. The different fetal tissues were simultaneously either submitted to enzymatic or non-enzymatic processing. Individual tissue biopsies from the FE002 donation were procured by the pathology department and further dissected into fragments, providing starting material for both cell isolation methods. All fragments were washed thrice in phosphate buffered saline supplemented with 1\% penicillin-streptomycin. (1) Fragments were then either appropriately dissected and placed in scored sterile culture dishes (i.e., non-enzymatic workflow) or subjected to appropriate trypsin digestion (i.e., enzymatic workflow) before plating in culture dishes. Sufficient amounts of seeded culture vessels were prepared for each individual tissue type and both cell isolation methods. Cells and tissue fragments were cultured in Dulbecco's Modified Eagle Medium (DMEM) supplemented with $10 \%$ clinical-grade fetal bovine serum (FBS). Cultures were incubated in a $37^{\circ} \mathrm{C}$ humidified incubator under $5 \% \mathrm{CO}_{2}$ and the growth medium was renewed every other day. (2) After rapid cell emission or free proliferation, preliminary cultures (i.e., P0) were harvested by trypsinization after attaining $90 \%$ confluency. (3) Cells were then enumerated and used to seed sufficient amounts of vented cell culture flasks for further expansion (i.e., P1). Culture medium was thereafter composed of DMEM, FBS, and additional L-glutamine. (4,5) Once optimal banking confluency was reached, cells at P1 were harvested, enumerated, and conditioned in individual $1 \mathrm{~mL}$ aliquots in a DMSO-based cryopreservation solution for long-term storage. $(6,7)$ Cryovials were frozen following a controlled rate and were transferred to the vapor phase of separate level-alarm-fitted locked Dewar storage tanks to constitute the Parental Cell Banks. Figure adapted with permission from Laurent et al. (2020e).

acid (HA). Additionally, synergistic in vitro effects are yielded by combining polycationic dendrimers and collagen matrices, providing potent anti-microbial effects coupled with keratinocyte migration stimulation and direct angiogenic effects (AbdelSayed et al., 2016). Further optimization of biological material processing will enable the transition from off-the-freezer to offthe-shelf therapies, with shortened production and availability delays, simplified logistics, and maintained therapeutic potential (Hunsberger et al., 2015; Li and Maitz, 2018). Probable therapeutic mechanisms of action of FPCs comprise paracrine signaling, with the release of well-proportioned arrays of growth factors or cytokines, and deposition of extracellular matrix (ECM) proteins in wounded environments (Spiekstra et al., 2007). Modulation of inflammation, cell migration and proliferation, immune system, and angiogenesis induction then leads to facilitated tissue repair or regeneration (Werner et al., 2007; Barrientos et al., 2008; Providence et al., 2008; Wojtowicz et al., 2014; Varkey et al., 2015). Due to the robustness of dermal FPCs, many alternative applications are envisioned for in vitro standardized models of screening assays or biotechnological manufacturing processes (e.g., feeder-layers, growth supplements for keratinocytes or MSCs, therapeutic cell-free extracts) (HirtBurri et al., 2011; Krähenbühl et al., 2015; Patrulea et al., 2015, 2019; Laurent et al., 2020e,i).

\section{Swiss Tools for Cutaneous Regeneration: Progenitor Biological Bandages}

Progenitor biological bandages (PBB) consist of moldable, singleuse, non-invasive bioresorbable wound coverages composed of dermal FPCs yielded by equine collagen scaffolds $(9 \mathrm{~cm} \times 12 \mathrm{~cm})$, which are currently GMP-manufactured and clinically delivered on-demand in less than $48 \mathrm{~h}$ to the Lausanne Burn Center (Figure 9). Advantages of PBBs comprise a simple and relatively painless one-step application, without staples, providing costeffective healing promotion within different types of cutaneous lesions (Abdel-Sayed et al., 2019a,b). Such constructs were successfully applied for various cutaneous conditions such as pediatric and adult severe burns, sharp-force trauma wounds, geriatric refractory chronic ulcers, and donor-site wounds, yielding unique reconstructive results (Figures 10, 11; 


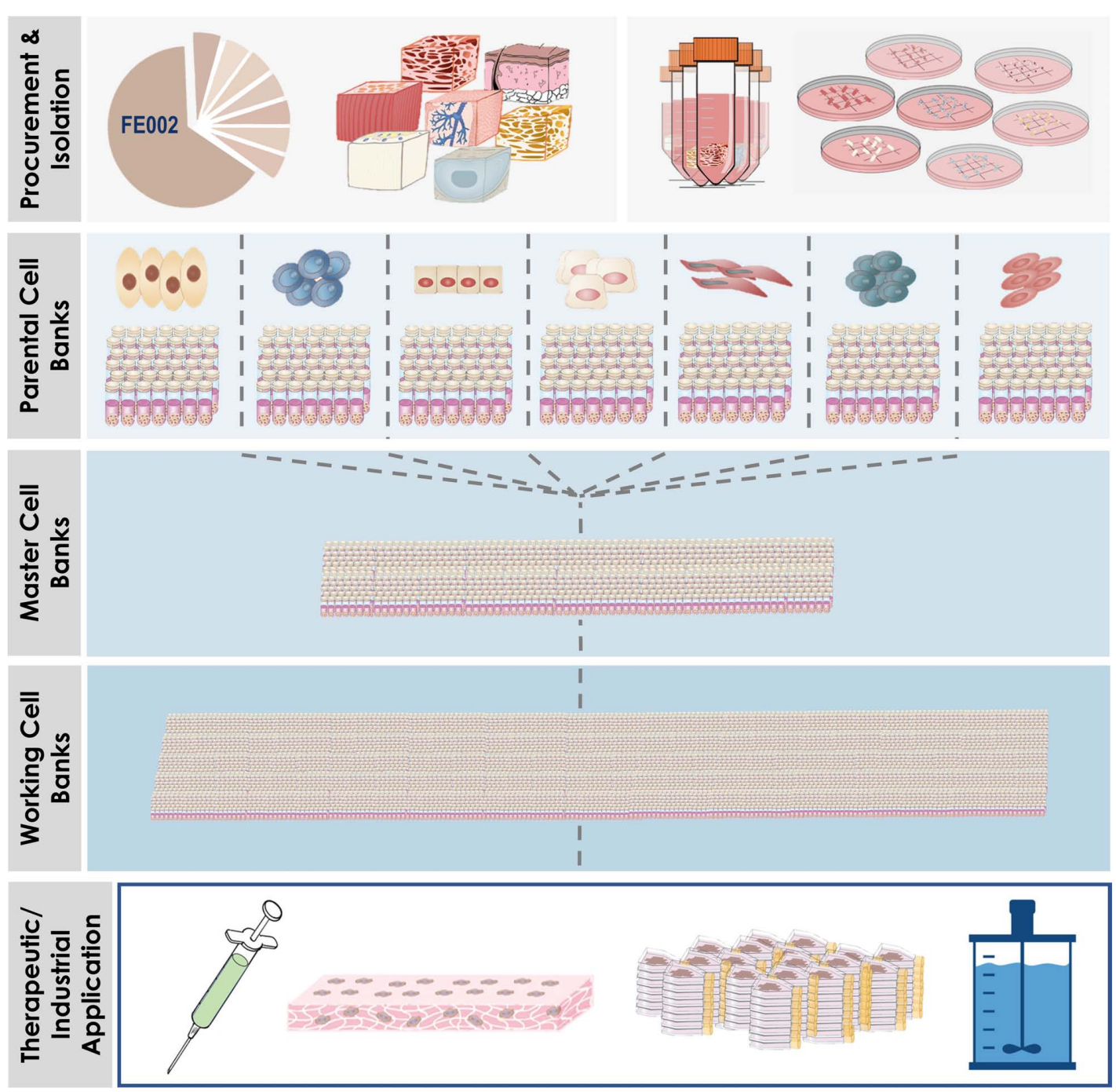

FIGURE 7 | Overview of simultaneous differential establishment of various primary FPC types following specific processing of biopsies from the same single organ donation (i.e., FE002, 2009). Procurement of the donation and micro-dissection enabled the specific tissue processing workflows to be implemented (i.e., enzymatic or non-enzymatic adherent cell culture initiation). Following the establishment of the tissue-specific FPC types, multi-tiered cell banking was performed in parallel for each specific cell type. Materials from Working Cell Banks were then used for diversified applications, which comprised or may comprise therapeutic live-cell product manufacture, use of FPCs or cellular materials as feeder-layers or culture supplements, and use of FPCs as substrates for biotechnological applications (e.g., viral vaccine production).

Hohlfeld et al., 2005; Ramelet et al., 2009; De Buys Roessingh et al., 2015). Skin regeneration was achieved extremely rapidly, with the restoration of high elastic properties and improved pigmentation balance, which was without pain, hypertrophy, retraction, inflammation, or the necessity for additional skin grafts. Bioengineered PBB constructs were observed to promote proliferation, adhesion, and migration of endogenous cells, without atrophic skin formation (Ramelet et al., 2009). Over two decades of clinical experience and multicentric studies have shown the safety or beneficial therapeutic effects of dermal FPCs in PBBs, notably within phase I and II clinical trials in Switzerland and Asia (i.e., ClinicalTrials.gov identifiers: NCT02737748 \& NCT03624023) (Hohlfeld et al., 2005; Ramelet et al., 2009; Laurent et al., 2020e). In view of further optimization of burn wound or ulcer care in particular, high therapeutic benefits may be gained by stabilizing and formulating active cell-derivative components in pharmaceutical creams, ointments, or gels, as these are used for the maintenance therapy to accelerate wound healing (i.e., potentially scarlessly) after primary wound closure.

\section{Human Cartilage FPCs (e.g., FE002-Cart, FE002-Cart.Art Cell Types)} Cartilage FPCs in Regenerative Medicine

Due to frequent cartilage defects caused by degenerative diseases or excessive wear, cell therapies, cell-based approaches, or combined bioengineered constructs are of high interest for translational medicine applications and predominate 


\section{TIERED GMP BIOBANKING OF PRIMARY FETAL PROGENITOR CELLS}

\section{CELL BANK}

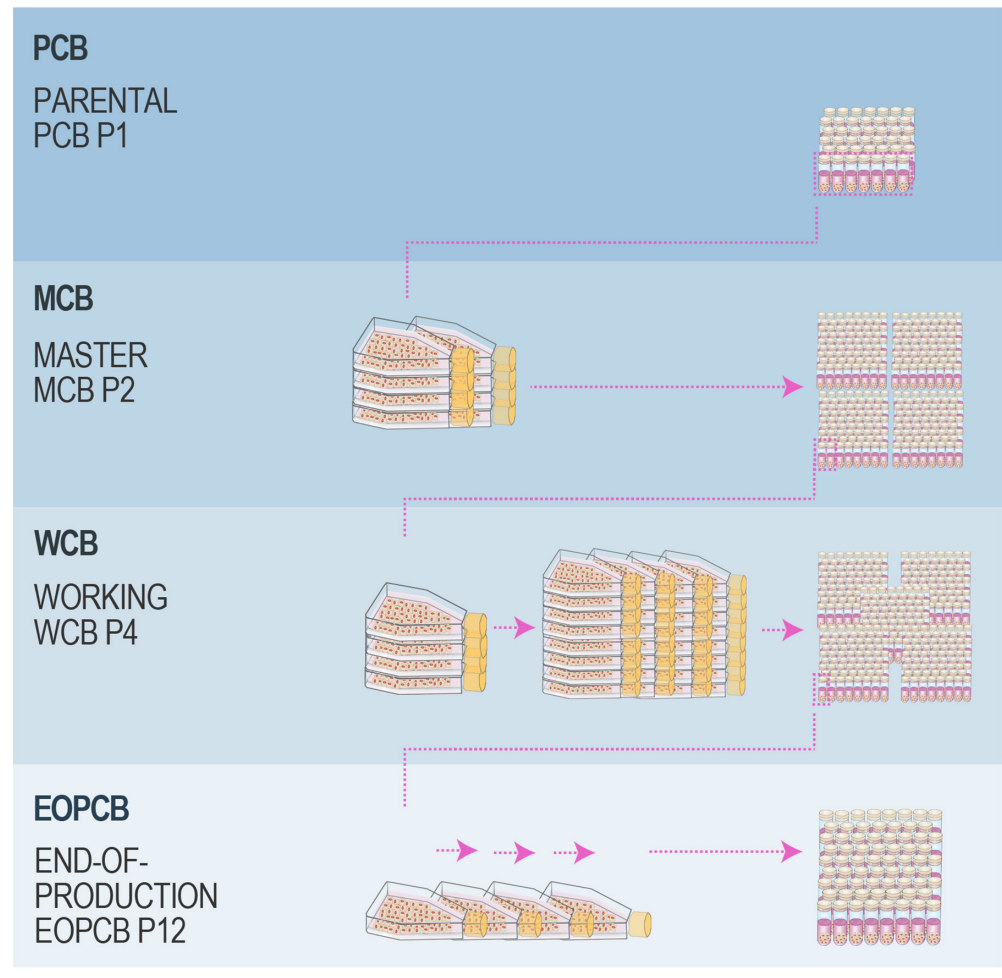

TESTING VALIDATION
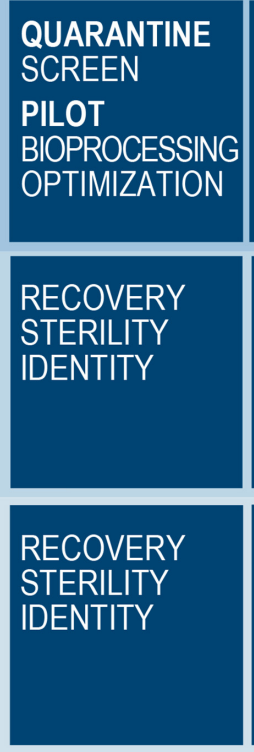

RECOVERY

STABILITY

SAFETY

in Vitro / in Vivo
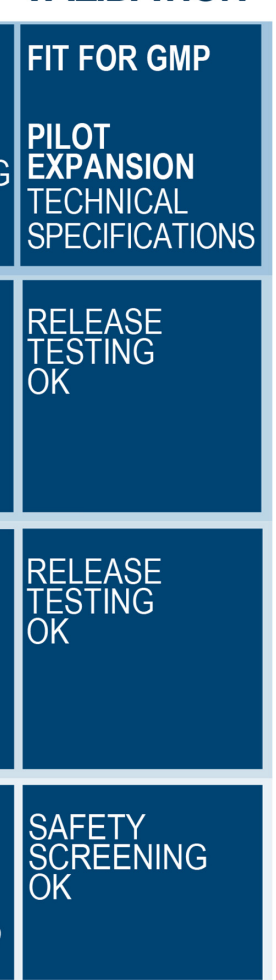

FIGURE 8 | Schematic overview of optimized and standardized multi-tiered cell banking workflows for primary FPCs. In vitro optimization steps performed during the pilot study may comprise serum lot choice, culture surface, and brand comparison, in order to maximize cell viabilities and population doubling values within minimal timeframes, obtaining the highest endpoint cell yields and best efficiency of manufacturing. Specific product release and characterization testing for the manufactured cell bank lots may comprise cell growth, isoenzyme testing to confirm cell type origin, DNA fingerprinting of the cell type, qualification/testing for sterility, specific testing for the absence of endotoxins, mycoplasma, viral contaminants (e.g., picornavirus, orthomyxovirus, paramyxovirus, adenovirus, reovirus, West Nile virus, BPyV, HuPyV, HPV, HBoV, WUPyV, KIPyV, EBV, HAV, HBV, HCV, hCMV, HIV-1, HIV-2, HTLV-1, HTLV-2, HHV-6, HHV-7, HHV-8, SV40, and B19 parovirus), evaluation of reverse transcriptase activity, and quantitative transmission electron microscopy (TEM) of cell sections for the detection of viruses, virus-like particles, mycoplasma, yeasts, fungi, bacteria (i.e., $\geq 200$ cell profiles). Safety assessments may be performed on EOPCB materials and comprise in vivo tumorigenicity assays and karyology studies. Nomenclature for correlated bank tier and passage numbers is provided here as an example, as it has been validated for dermal FPCs (i.e., FE002-SK2 cell type). The devised technical specifications, testing, and validation strategies are optimally adapted for banking FPCs, due to the inherent high robustness, consistency, and stability of the considered cellular materials. Industrial transposition towards GMP production is therefore tangibly attained with such materials, as extensive multi-tiered cryopreserved cell banks may be rapidly and efficiently established. Figure adapted with permission from Laurent et al. (2020e).

developmental efforts (Vrahas et al., 2004; Flanigan et al., 2010; Makris et al., 2015; Carluccio et al., 2020). The avascular and alymphatic nature of cartilage tissues confers relative immune privileges (i.e., isolation from antigen-presenting cells, migratory macrophages, and dendritic cells) and renders allogenic cell therapy approaches possible for tissue regeneration chaperoning (Quintin et al., 2010; Studer et al., 2017). Autologous cartilage cell therapy implementation remains hindered or delayed due to the induction of hypertrophic tissue phenotypes, fibrocartilage formation, high-cost cell expansions, in vitro de-differentiation, two-step surgery, donor-site morbidity, and high variability in functional outcomes (Brittberg et al., 1994; Horas et al., 2003; Lu et al., 2006; Katopodi et al., 2009; Vinardell et al., 2012).
Differential autologous and allogenic approaches comprise high cellular variability, and related inhomogeneous potency restricts potential therapeutic benefits (Wakitani et al., 2007; Stolzing et al., 2008; Prockop, 2009; Pelttari et al., 2014; Pleumeekers et al., 2014; Steinwachs et al., 2014). Neonatal chondrocytes or cartilage FPCs are optimal candidates for cell therapies, possessing relatively superior chondrogenic potential (i.e., constitutive immature chondrodifferentiation for the latter cell types) than adult chondrocytes (Almqvist et al., 2009; Adkisson et al., 2010a,b; Quintin et al., 2010; Acosta et al., 2011; Darwiche et al., 2012; Dhollander et al., 2012; Cavalli et al., 2018). Fetal progenitor cells also present relatively low hypertrophy marker expression (e.g., type $\mathrm{X}$ 

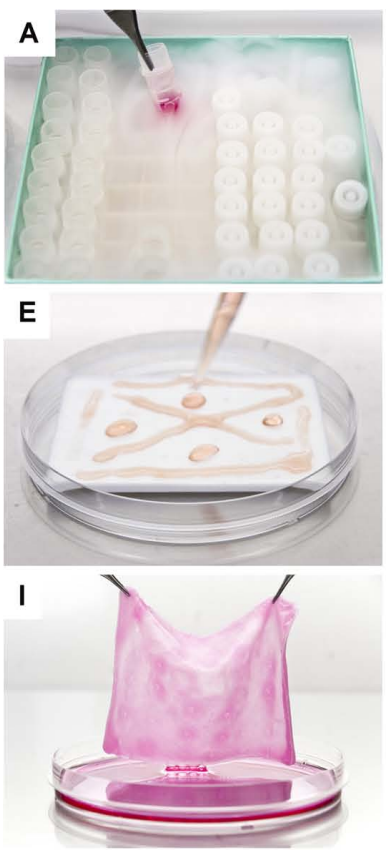
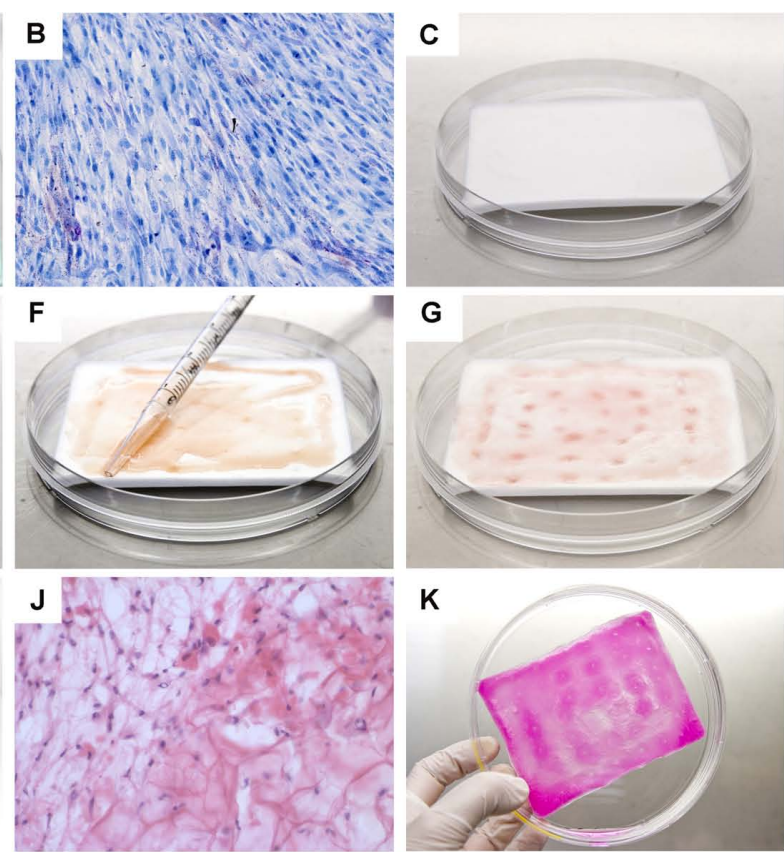

G
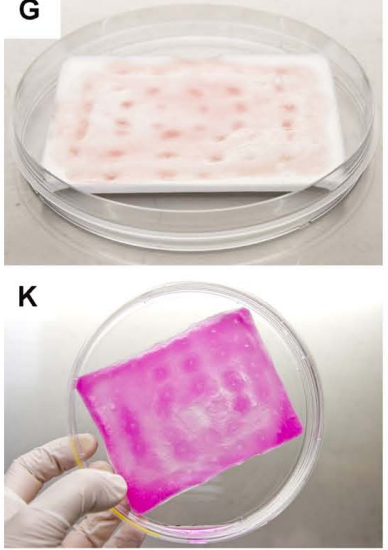

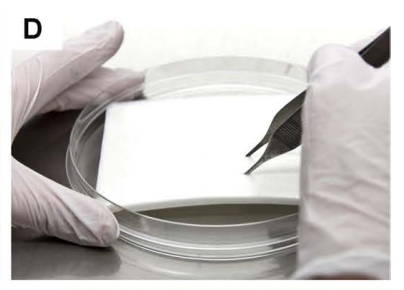

H
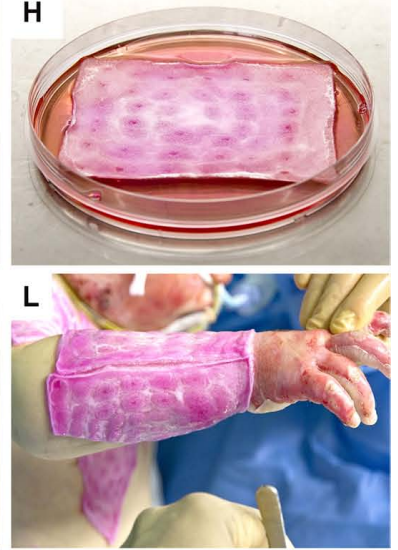

FIGURE 9 | Photographic illustrations providing an overview of the supply chain and manufacturing steps necessary for the preparation of Progenitor Biological Bandages (PBBs), following GMP standards, for clinical application in the Lausanne Burn Center. (A) Upon manufacturing order receipt from the clinic, vials from the dermal FPC Working Cell Bank (i.e., FE002-SK2 WCB, P7-P8) are selected and initiated for therapeutic construct preparation. (B) Cell suspensions are thawed and cellular viability is assessed. (C) Sufficient amounts of equine collagen scaffolds are procured. (D) Scaffolds are pre-conditioned by symmetrical puncture of the whole surface. (E) Cells are rinsed and seeded on the scaffolds. (F) Cell suspensions are further homogenously distributed over the integral surface of the scaffold, to allow optimal cell colonization and integration. (G) Seeded scaffolds are further processed to allow uptake of cell suspensions. (H) Constructs are incubated for $24-48 \mathrm{~h}$ at $37^{\circ} \mathrm{C}$ under $5 \% \mathrm{CO}_{2}$. (I) After incubation, the scaffolds are checked following quality assurance specifications. (J) Histological investigation of a cell-seeded construct (i.e., PBB) after snap-freezing and staining with hematoxylin and eosin. (K) PBBs are rinsed and delivered to the operating theater in isotherm containers. (L) After standard surgical wound care and disinfection, the constructs are applied and subsequently overlaid with bandages to favor wound healing rate acceleration.

collagen), possibly due to epigenetic modulations in vivo (Zimmermann et al., 2008; Tompkins et al., 2013). Clinical translation of therapeutic cartilage FPCs is appealing due to the potential to consistently treat large numbers of patients (i.e., $>10^{8}$ individual therapies consisting of cell-seeded biocompatible implants following a single fetal organ donation) (Darwiche et al., 2012).

\section{Phenotypic Stability, Chondrogenic Potential, and Biomechanics}

High phenotypic stability and chondrogenic potential (i.e., elevated sulfated GAG content, Sox9:Scleraxis ratios, $I H H$ and PTH1R gene expression, TGF- $\beta 3$-induced production of aggrecan, types I+II collagen) of cartilage FPCs are differential advantages supporting their application in tissue engineering (Broguiere et al., 2016; Studer et al., 2017). Despite expressing stem cell surface markers, cartilage FPCs present relatively lower adipogenic and osteogenic differentiation capacities on a site-specific basis (Stokes et al., 2002; Quintin et al., 2010). Conjugation with alginate optimally stimulates and maintains ECM production, while resisting mineralization and circulatory vessel infiltration in vivo, thereby drastically improving stability and therapeutic potential of cartilage FPCs, along with optimal structural parameters (Häuselmann et al., 1994;
Mellor et al., 2014; Mhanna et al., 2014; Studer et al., 2017). Polyethylene glycol, chitosan, albumin, or hyaluronan scaffolds have been investigated as functional cell vectors for injectable applications, yielding adhesive, chondrogenic, and mitogenic properties (Madeira et al., 2015; Mardones et al., 2015). For combination product assembly, impermeable, tortuous, and hydrophobic scaffolds often present resistance to liquid phase infiltration, despite high porosity and relative void volume, which negatively affect cell integration, colonization, and persistence (Wendt et al., 2003; Solchaga et al., 2006; Melchels et al., 2010). Various dynamic cell seeding protocols for the induction of active infiltration (e.g., perfusion, centrifugation, orbital shaking, spinner flasks) allow cell distribution uniformity and optimal preservation of cellular integrity and function (Burg et al., 2000; Alvarez-Barreto et al., 2007; Roh et al., 2007; Thevenot et al., 2008). An equilibrium must be reached between cell proliferation and adequate chondrogenesis (i.e., responsiveness versus stability) following homogeneous scaffold seeding, directly defining adequate seeding density, methods for construct obtention, and preculture conditions (Roche et al., 2001; Moretti et al., 2005; Hasegawa et al., 2010; Erickson et al., 2012; Nasrollahzadeh et al., 2017; Studer et al., 2017). This ultimately results in the integration of structural and mass transport properties with the functional chondrogenesis components 

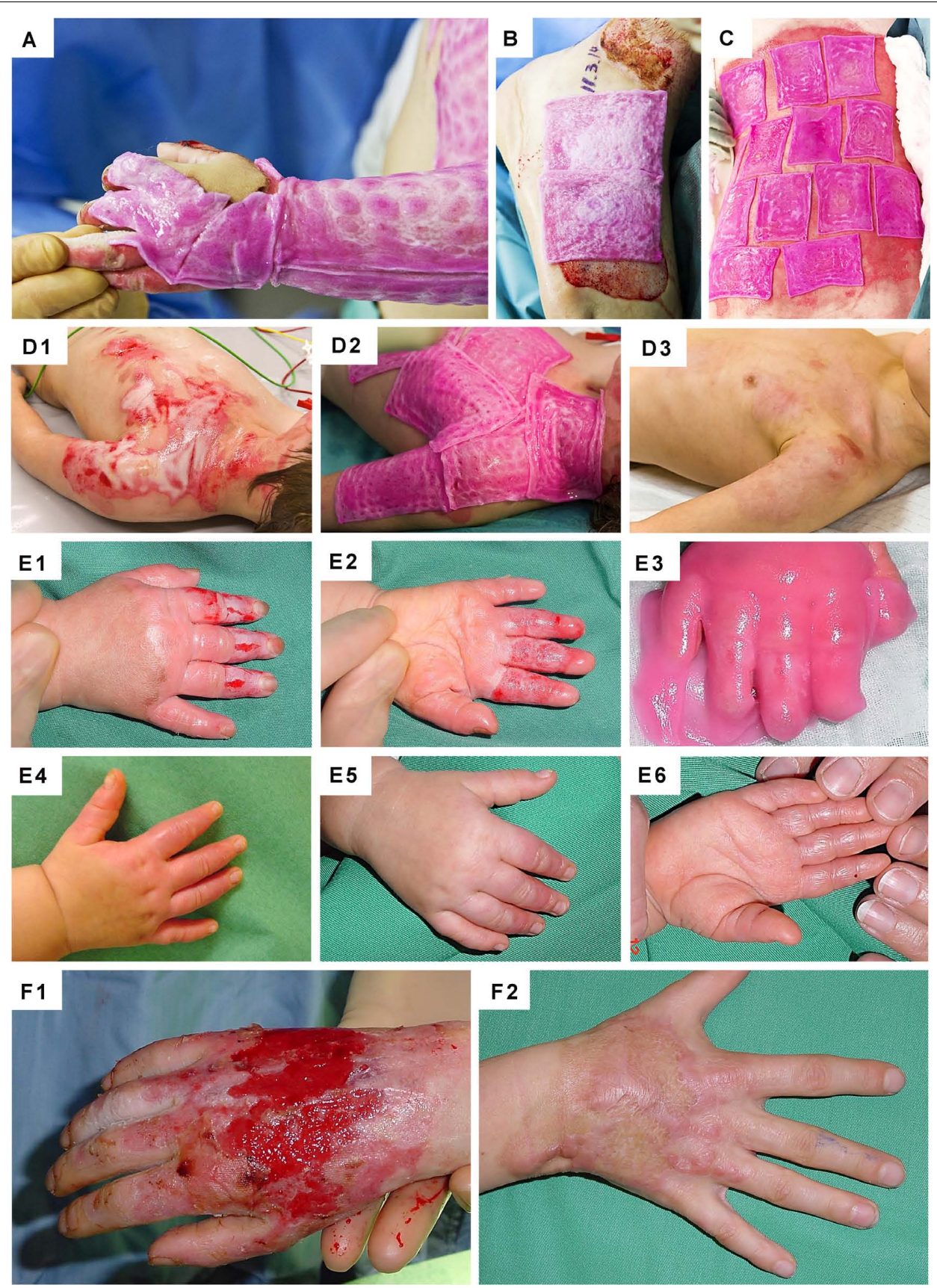

FIGURE 10 | Clinical case-reports illustrating the use and efficacy of Progenitor Biological Bandages for the management of human pediatric burns and donor-site wounds. (A-C) Photographic representation of Progenitor Biological Bandages used for primary lesions of a pediatric burn victim and donor-site graft secondary wounds. Unlike skin autografts or synthetic wound coverage solutions, PBBs do not need to be stapled to the patient, as they are simply applied and overlaid with Vaseline gauze before standard bandages are adjusted. (D1-D3) Second-degree deep pediatric burn wound (i.e., scalding liquid). Photographic representations of the lesions after early debridement, after PBB application, and after six weeks of treatment. (E1-E6) Second and third-degree pediatric burn wound (i.e., scalding liquid). Photographic representations of the lesions after early debridement, after PBB application, and after six weeks of treatment. (F1-F2) Second-degree pediatric burn wound (i.e., scalding liquid). Photographic representations of the lesions after early debridement and after ten years during patient long-term follow-up. Figures modified with permission from Hohlfeld et al. (2005) and Laurent et al. (2020a).

of the cells, which enable load bearing after successful implantation and integration (Hollister, 2005; Kemppainen and Hollister, 2010). External or internal biochemical modulation, specific processing (e.g., microgel encapsulation), and scaffold mechanical stimulation differentially constitute potent cues for chondrogenesis and structural or functional improvement in bioengineered constructs (Huang et al., 2005, 2010; Campbell et al., 2006; Terraciano et al., 2007; Levinson et al., 2019; 


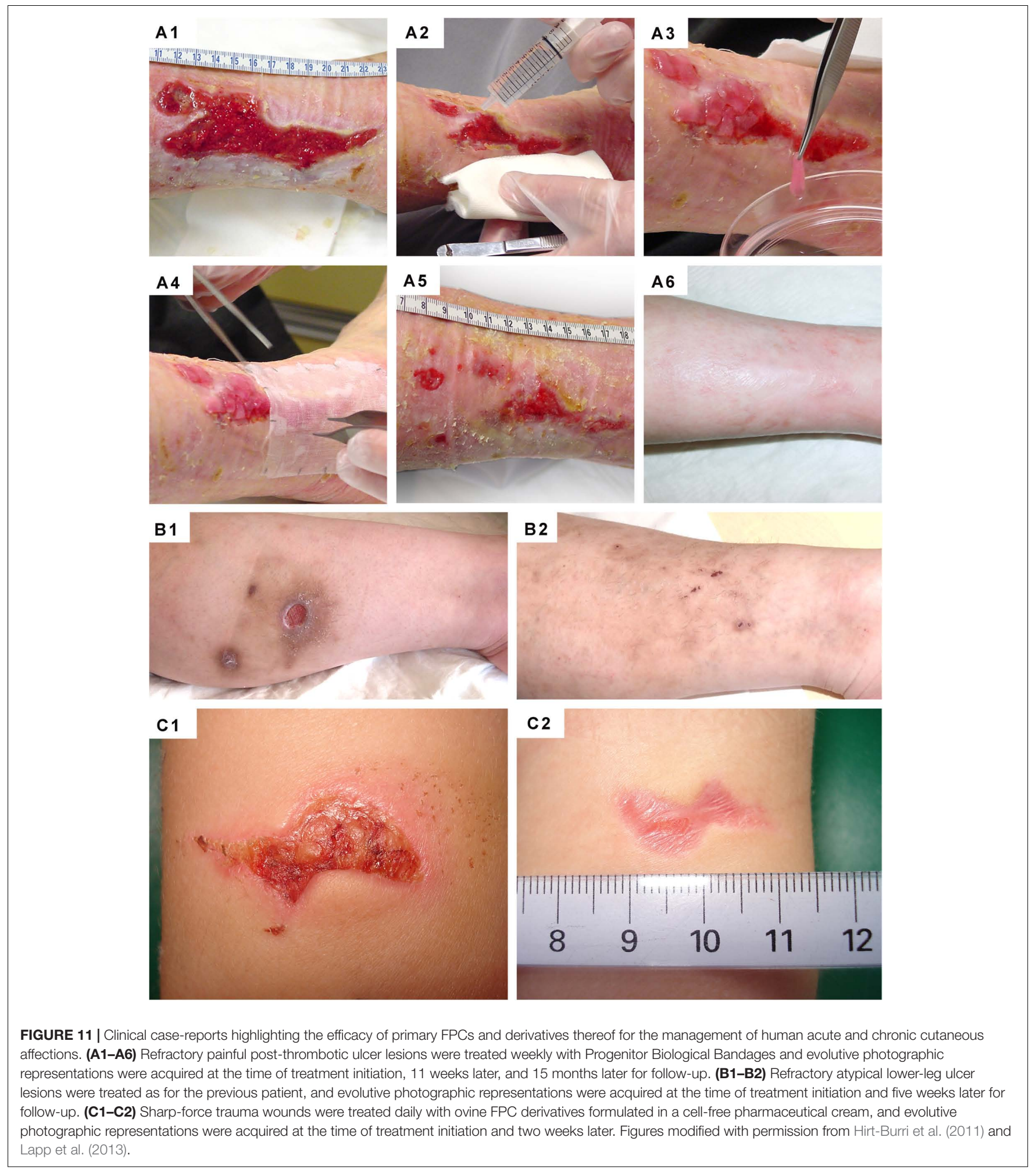

Li et al., 2020). Scaffold stiffness improves with ECM deposition and may approach physiological ranges in clinically relevant timeframes (Broguiere et al., 2016). Controlled and functionoriented energy dissipation modulation within native viscoelastic cartilage-like materials favors optimal chondrogenic expression under dynamic loading and subsequent load-bearing (Hunter et al., 2004; Shaw and MacKnight, 2005; Li et al., 2010; AbdelSayed et al., 2014). Relatively high energy dissipation levels lead to the upregulation of specific chondrogenic markers (e.g., mRNA of Acan, Col2a1, Sox9, and TGF- $\beta 3$ ), while lower 
dissipation is linked to downregulation (Mauck et al., 2007; Thorpe et al., 2008; Abdel-Sayed et al., 2014).

\section{Human Tendon FPCs (e.g., FE002-Ten Cell Type) for Regenerative Medicine}

Tendinous tissue disorders (e.g., tendinosis, lipoid degeneration, and calcification), along with imperfect inherent tissue healing capacities and iatrogenesis, result in disability, chronic pain, functional, and productivity deficits, particularly in sporting and manual labor areas. These diseases or injuries implicate highly specialized professional care and high burdens for public healthcare systems (Verdan, 1972; Kannus and Józsa, 1991; Maffulli et al., 2003; Sharma and Maffulli, 2005; Tuncali et al., 2005; Reinking, 2012). Adhesions and high rates of secondary ruptures are current clinical concerns, as functionally defective fibrotic scar tissue accumulates (James et al., 2008). Slow inherent tissue metabolism, delayed inflammation, effector recruitment, ECM deposition, tissue architectural reorganization, and alignment render the modulation of tendon regeneration complex (Sharma and Maffulli, 2005; Voleti et al., 2012). The efficacy of tendon transfer is hindered by accelerated graft degeneration and would largely benefit from therapeutic cell stimulation, ideally leading to optimal elasticity, mobility, and tensile strength restoration (O'Brien, 1997; Kannus, 2000). Bioengineering scaffolds of interest, such as human cadaveric and equine decellularized tendons or artificial equivalents, enable optimal maintenance of biocompatibility, mechanical properties, and susceptibility for cell seeding, whereas autologous vestigial tendons remain as the standard of care (Wehbé, 1992; Chong et al., 2009; Jakubietz et al., 2011; Pridgen et al., 2011; Burk et al., 2016; Lovati et al., 2016; Valentin et al., 2016; Aeberhard et al., 2019). Vast arrays of potential therapeutic cell types have been investigated in tendon bioengineering for regeneration enhancement, including tendon sheath fibroblasts, adult tenocytes, stem cells, placenta cells, amniotic cells, and platelet-derivatives (Kadner et al., 2002; Kaviani et al., 2002, 2003; Awad et al., 2003; Chen et al., 2009; Akhundov et al., 2012; Xu et al., 2013; Petrou et al., 2014). Tendon FPCs present tremendous therapeutic potential due to high stability of their tenogenic and karyotypic properties in culture, low propensity for dedifferentiation, expansion characteristics, therapeutic stimulatory potential, and the ability to maintain cell viability along with rheological properties of bioengineered hydrogel constructs (Grognuz et al., 2019). Their similarities with stem cells but lack of specific tendon markers require in vitro characterization of tendon FPCs using marker panels (e.g., type I collagen, scleraxis, and tenomodulin) (Hulmes, 2002; Le Blanc et al., 2003; Docheva et al., 2005; Murchison et al., 2007; Banos et al., 2008; Taylor et al., 2009). Extensive tendon FPC cell banks may be consistently established and yield approximately $2 \times 10^{14}$ cells within the clinically relevant in vitro lifespan, potentially serving for the manufacture of more than $10^{8}$ treatment units (e.g., reseeded biocompatible scaffolds for localized tendon replacement) (Grognuz et al., 2016b). Relatively increased ECM production is achieved by tendon FPCs under appropriate conditions, as compared to primary adult tenocytes. Development of injectable products designed for tissue regeneration stimulation (e.g., degenerative diseases, small hand injuries, fissures or partial ruptures) using registered medical devices without cell preculture periods enables tangible translational development (Petrou et al., 2014; Grognuz et al., 2016a).

\section{Human Muscle FPCs (e.g., FE002-Mu Cell Type) for Regenerative Medicine}

Intrinsic potential for functional rearrangement and healing is low in human muscle tissue, further diminishing with the advancement of biological age (Grasman et al., 2015; Passipieri and Christ, 2016). Without effective therapeutic management, severe and extensive tissue structural bias (e.g., volumetric muscle loss) is often predictive of poor clinical outcome, as spontaneous optimal healing is hindered or negated, which results in diminished contractility associated with fibrotic tissue formation (Montarras et al., 2005; Ciciliot and Schiaffino, 2010; Grogan et al., 2011; Sicari et al., 2014; Duffy et al., 2016). Muscular tissue engineering is designed to effectively manage and restore structure and function in the aftermath of intense soft tissue trauma, burns, malformations, or tumor ablation, while minimizing volumetric loss and donor-site morbidity consequences (Laurent et al., 2020c). Traditional reconstructive surgical care may tangibly and synergistically benefit from supplementation with cell therapies. Immune rejection, poor distribution, and extremely restricted cell persistence after implantation have been significant challenges limiting the potential of myoblast transfer therapy in muscular loss, Duchenne muscular dystrophy, or cardiac surgery (Partridge et al., 1978; Mendell et al., 1995; Miller et al., 1997; Skuk and Tremblay, 2000; Smythe et al., 2000; Huard et al., 2002; Menasché, 2005). Such obstacles dramatically hamper therapeutic efficacy, as eventual functional benefits are dependent on cell survival in situ (Fan et al., 1996; Beauchamp et al., 1997, 1999; Qu et al., 1998; Hodgetts et al., 2000, 2003; Tambara et al., 2003; Sammels et al., 2004). Multimodal development efforts have been allocated to optimize persistence and therapeutic effects of implanted cells, comprising differential cell source choice, cell population purification and pre-treatment, or modulation of existing pharmacotherapeutic care protocols (Huard et al., 1994; Pavlath et al., 1994; Guérette et al., 1997; Qu et al., 1998; Jankowski et al., 2001; Maurel et al., 2005; Schäfer et al., 2006). Defined cell population identity and high purity of human muscle FPCs (i.e., stable desmin expression) or in vivo persistence were demonstrated in immunocompetent murine models, excluding immunogenicity and tumorigenicity, while positively affecting contractile recovery potential (Hirt-Burri et al., 2008a; Laurent et al., 2020c). Specific estimations indicate that a single fetal organ donation can potentially yield more than $10^{12}$ progeny cells at a low passage (i.e., $\mathrm{P} 4$ ), enabling subsequent safe industrial-scale manufacturing of off-the-freezer therapeutic cellular products. High FPC robustness and adaptability to bioengineered scaffolds, such as equine collagen sheets, were shown, with rapid colonization and proliferation of therapeutic cells in vitro, and persistence thereof in vivo (Hirt-Burri et al., 2008a). Optimal restoration of muscle tissue function was 
demonstrated, concerning functional endpoints of tissue repair, following engraftment of human muscle FPCs in a murine model for volumetric muscle loss (Laurent et al., 2020c).

\section{Human Bone FPCs (e.g., FE002-Bone Cell Type) \\ Bone FPCs for Skeletal Tissue Engineering}

Conventional specific surgical management strategies for bone injuries or diseases include autografting, allografting, or xenografting, which retain relatively elevated risks of contamination and immune response eliciting, leading to subsequent invasive procedures (Younger and Chapman, 1989; Strong et al., 1996; Vacanti et al., 2001; Schantz et al., 2002; Tenorio et al., 2011). Bone replacement and skeletal regenerative cell therapies focus mainly on orthopedic medicine, osteogenesis imperfecta, and mandibular care (Horwitz et al., 1999; Ohgushi and Caplan, 1999; Yildirim et al., 2000; Bianco et al., 2001; Patino et al., 2002; Rose and Oreffo, 2002; Mauney et al., 2005; Oreffo et al., 2005; Yoshioka et al., 2007; Mendes et al., 2008). Use of FPCs for skeletal tissue engineering eliminates the need for extensive population selection and complex biochemical phenotype manipulation, while cells maintain sustained differentiation states, with relevant mineralization activities in vitro and in vivo (Petite et al., 2000; Parikh, 2002; Gronthos et al., 2003; Mendes et al., 2004; Montjovent et al., 2004, 2008, 2009). Allogenic FPC supplementation in artificial bone constructs facilitates cell migration, proliferation, and differentiation at the injury site after implantation, in order to favor tissue regeneration (Caplan and Goldberg, 1999; Shea et al., 2000).

\section{Bone FPC Modulation and Drug Delivery}

Osteogenic activity (e.g., dexamethasone-induced cbfa-1, ALP, type I collagen, and osteocalcin gene expression) and mineralization processes are comparatively superior in magnitude or more rapid in FPCs than in stem cells and adult osteoblasts, whereas orientation toward mature osteoblast differentiation is relatively simple (Zernik et al., 1990; Franceschi, 1999; Karsenty, 2000; Pioletti et al., 2006). Fetal progenitor cell expansion and migration are culture medium-dependent and sensitive to PDGF-BB, FGF-2, or BMP-2 stimulation (Krattinger et al., 2011). Constitutive expression of TGF, VEGFA, EDN1, IL-6, and MCP-1 in FPCs was shown, along with characteristic markers (e.g., Stro-1, ALP, CD10, CD44, CD54, $\beta 2$-microglobulin, HLA-I, CD80) (Montjovent et al., 2009). Fetal progenitor cells present a tendency toward osteogenic differentiation, whereas specific modulation is achieved using ascorbic acid, glycerophosphate, 1 1 ,25-dihydroxyvitamin D3, or dexamethasone, and may be evaluated by monitoring the expression levels of RUNX2, OSX, or SOX9 (Aubin, 1998; Gallagher, 2003; Krattinger et al., 2011). Bone FPCs display the characteristics of osteoprecursor cells, relatively more advanced in terms of differentiation than stem cells, and produce relatively superior quantities of ECM, whereas fully-induced differentiation processes result in the appearance of specifically mineralized bone-like nodules (Montjovent et al., 2004; Krattinger et al., 2011). Phenotypic maturation in vivo was shown to not carry the immune privileges of therapeutic FPCs in rodent models (Hausherr et al., 2017). Chemical functionalization (e.g., click chemistry, bioorthogonal chemical reactions, covalent binding) of therapeutic cell surfaces allows optimal conjugation with bioengineered scaffolds, while maintaining and optimizing cellular viability, adhesion, persistence, and function (Borcard et al., 2011, 2012; Comas et al., 2012; Krauss Juillerat et al., 2012). Optimal mechanical properties and efficient vascularization capacity of implanted constructs are essential, while biodegradable hydrogels may enable local cell maintenance (Tenorio et al., 2011; Amini et al., 2012). For critical-size bone tissue replacement, cyto- and histo-compatible permanent bone-mimicking substitute materials (e.g., bioceramics) must comprise trans-scaffold micro-structure channels enabling nutrient diffusion and migration (i.e., pore size-dependent osteoconduction) of therapeutic cells, to ensure permanent cellularization and sustained functionality (Triplett and Schow, 1996; Ducheyne and Qiu, 1999; Griffith and Naughton, 2002; Montjovent et al., 2007, 2008; Klenke et al., 2008; Krauss Juillerat et al., 2012). The temporal onset of construct preculture mechanical loading influences and regulates bone architectural properties, whereas early or delayed loading may be beneficial for bone tissue formation within short timeframes (Carter et al., 1989; Huiskes et al., 2000; Roshan-Ghias et al., 2010; Boerckel et al., 2012). Based on in vivo experiments, it was established that low predictability characterizes the specific behavior of a given cell type and scaffold conjugate, concerning the intensity and temporal onset of mechanical loading (Hausherr et al., 2018). High cellular resistance to shear stress enables extrusion of cell-laden hydrogels through small-bored needles without compromising cellular viability, whereas HA constitutes a versatile and functional scaffold, allowing relatively enhanced cell migration at the delivery site and ameliorated therapeutic stimulation (Drury and Mooney, 2003; Weinand et al., 2006). Similar valuable characteristics (i.e., absorption, biocompatibility, chemotactic activities, void filling, and migration enhancement) are shared by collagen scaffolds (Patino et al., 2002).

\section{Human Intervertebral Disc FPCs (e.g., FE002-Disc Cell Type) for Regenerative Medicine}

The widespread prevalence of intervertebral disc degeneration mainly contributes to back pain-related surgical management and spine surgeries (Urban and Roberts, 2003; Anderson and Tannoury, 2005; Haefeli et al., 2006). Intervertebral disc tissue is characterized by mediocre intrinsic regenerative potential, further complicating therapeutic management and advancing the onset of degenerative disease. Cell therapy approaches for disc degeneration prevention present considerable potential for replacing autologous nucleus pulposus transplantation (Ganey et al., 2003; Sato et al., 2003; Crevensten et al., 2004; Meisel et al., 2006, 2007; Sakai et al., 2006). After intervertebral FPC isolation and during subsequent characterization, both structure and composition of ECM (e.g., aggrecan, type I and II collagen, sulfated GAGs), spontaneously produced by intervertebral disc FPCs, approach those of adult origin, as observed in alginate 
bead culture, outlining the full chondrogenic differentiation potential (Häuselmann et al., 1994; Mok et al., 1994; Chiba et al., 1997; Melrose et al., 2000; Quintin et al., 2009). Absence of specific markers enabling population purity assessment prompts, for each new fetal organ donation and derived primary cell type, close evaluation of phenotypic consistency and stability for intervertebral disc FPCs, as they represent mixed populations isolated from whole spine units (Quintin et al., 2009). Therefore, based mainly on the initial dissection and culture initiation methods, some cell types may be unfit for further processing and should be excluded at an early stage, based on characterization results. Interestingly, intervertebral disc FPCs presented relatively lower adipogenic differentiation potential than comparable cartilage FPCs (Quintin et al., 2010). Overall, accumulated data strategically positions intervertebral disc FPCs for further research and development in skeletal tissue regeneration applications.

\section{Human Lung FPCs (e.g., FE002-Lu Cell Type) for Biotechnological Manufacturing or Regenerative Medicine}

Lung FPCs present tremendous potential and vast hindsight for applications in biotechnology, as the vaccine industry has been using such cell types for half a century. The finite human diploid MRC-5 cell type was initially isolated in the 1960s from a male fetal lung (i.e., 14-week gestational age), donated following a pregnancy interruption, and has been used as a substrate for manufacture of chickenpox, hepatitis A, polio, smallpox, and rabies vaccines (Jacobs et al., 1970; Lewis and Tarrant, 1972; Petes et al., 1974). Safety, stability, and quality of substrate cell types are of paramount importance, as defects may be passed down to therapeutic products and eventually endanger patients. Some concerns have emerged following reports that MRC-5 fibroblasts could de-differentiate under specific conditions and exhibit different markers typically found in ESCs or MSCs and neural tissue, or further become osteoblasts (Rieske et al., 2005; Zhang et al., 2014; Wan et al., 2018). Such capabilities tend to indicate a relative instability of the considered cell type, potentially creating problems in modern-day industrial validation. Additionally, aging of the MRC- 5 cells, recurrent doubts about the identity of currently marketed MRC-5 cells, and unavailability of these in different geographical regions have led to the establishment of replacement cell types. Modern alternatives were reportedly developed (e.g., Walvax-2 cell type, PRC), with particular attention being paid to the ethnicity of the donor, in order to optimize industrial outputs by exploiting shorter doubling times, improved robustness, or cell viability (Ma et al., 2015). Recently established primary lung FPCs, such as the FE002-Lu cell type, benefit from all the aforementioned technical advantages of FPCs, and may be expanded at full industrial scale within specific multi-tiered cell banking workflows, therefore potentially constituting a tangible candidate for the replacement of the MRC-5 cell type. Optimization of novel and safe cellular substrates shall allow for the optimal replacement of biotechnological intermediates for vaccine production, therefore indirectly contributing to augmenting the quality of therapeutic products, benefiting populations globally. Additionally, primary lung FPCs may present substantial therapeutic utility in treating lung tissue inflammatory diseases. Recent clinical studies (i.e., ClinicalTrials.gov identifiers: NCT04315987, Brazil; NCT04313322, Saudi Arabia; NCT04333368, France; ChiCTR2000029990, PRC) are advancing with the use of multiple therapeutic stem cell sources for managing COVID19 patients (Zhao, 2020). Similarly, it is hypothesized that lung FPCs may provide enhanced anti-inflammatory and tissue regeneration stimulation, as observed within cutaneous regenerative applications of related dermal FPCs. Meanwhile, the tissue-specific origin and high consistency or stability of such cell types may prove to be the optimal parameters for standardized therapeutic success.

\section{Single Tissue Donation for Multiple Mammalian FPC Types Ovine FPCs and Cell-Based Cell-Free Topical Preparations}

In addition to therapeutic cell roles for tissue-engineered products, banked primary FPCs are well adaptable as intermediates/substrates in the supply chain of therapeutic and medical (e.g., medical devices) or cosmetic/cosmeceutical products, targeting mild to moderate cutaneous diseases or states, such as acne scars, post-laser maintenance, physiological aging marks, burns, and wounds (Limat et al., 1996; Fitzpatrick and Rostan, 2003; Wu et al., 2003; Gold and Biron, 2006; Gold et al., 2007). Various cutaneous/ectodermal and musculoskeletal ovine FPC types (i.e., isolated from skin, muscle, connective tissue) have been established in collaboration with the food industry for further processing, culture-expansion, multi-tiered banking, and the eventual inclusion of cell-free derivatives in stabilized biopharmaceutical topical preparations, achieving further optimization of primary FPC banking for regenerative cutaneous applications (Lapp et al., 2013). Ovine primary FPC types were found to adapt to standardized whole-cell bioprocessing and out-scaling frameworks optimally (i.e., efficiently outperforming human FPC types), characterized by optimal expansion kinetics and remarkable in vitro stability (i.e., extensive lifespan, protein concentration regularity), and normalized efficacy in co-culture models. Carefully balanced derivative combinations in near homeopathic relative quantities yielded optimal stimulatory results, indicating complementary or synergistic effects of various specific active principles. Pharmaceutical-grade cell-free preparations were applied for veterinary and human case studies (i.e., wounds and burns), yielding efficient results for aiding tissue repair (Figure 12). Additionally, a significant technological advantage exists in the stabilization of the therapeutic potential of ovine FPCs, consistently retaining and preserving initial physiological properties and therapeutic attributes, via derivation of cell-free extracts. In addition, the formulation of the latter in ready-to-use topical pharmaceutical delivery forms with extensive shelf lives compared to fresh living cells is another advantage (Lapp et al., 2013). Such preparations appear well suited for maintenance therapies within consolidated wound repair strategies, or as specific topical regenerative solutions, depending on dosage and formulation type. 

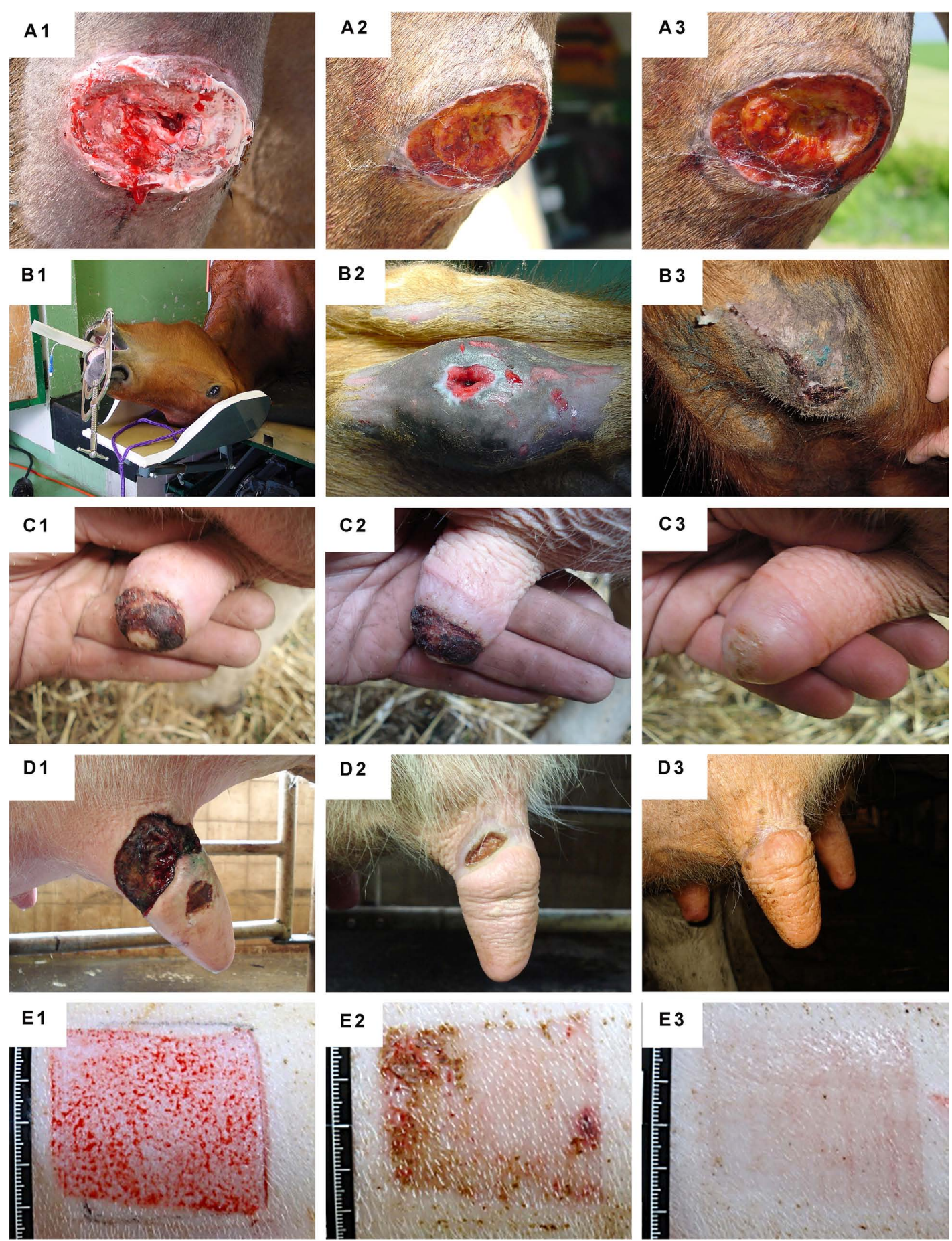

FIGURE 12 | Clinical veterinary case-reports illustrating the use and efficacy of equine Progenitor Biological Bandages, ovine FPC derivatives formulated as creams, and human dermal FPCs formulated in hydrogels for the management of animal traumatic injuries and donor-site wounds. (A1-A3) Profound distal limb articular lesion on the right hind knee of a French Saddlebred Pony (i.e., caused by a severe fall against barbed wire). The lesion was treated with ePBBs and bandages were removed after three days. (B1-B3) Mandibular fistula created by an abscessed tooth on a Franche-Montagne horse. The lesion was treated with ePBBs and bandages were removed after nine days. (C1-C3) Cow udder having suffered compression force trauma. Cell-free cream containing ovine FPC derivatives was applied daily. Photographic representations of the lesions at the beginning of treatment, after two weeks, and after seven weeks. (D1-D3) Cow udder having suffered sharp force trauma. The same cream was applied daily. Photographic representations of the lesions at the beginning of treatment, after seven weeks, and after nine weeks. (E1-E3) Porcine skin model for donor-site wound healing stimulation evaluation using human dermal FPCs (i.e., FE002-SK2 cell type) formulated in hydrogels. Photographic representations of the lesions at the beginning of treatment, after six days, and after 14 days. Figures modified with permission from Lapp et al. (2013) and Laurent et al. (2020e). 


\section{Equine FPCs in Hippiatric Regenerative Medicine}

Based on the extensive experience in the regenerative potential of primary human and ovine FPC types isolated from various cutaneous and musculoskeletal tissues (i.e., skin, muscle, cartilage, tendon, connective tissue, and bone) of single fetal organ donations, the optimized fetal transplantation framework was applied to equine tissue biopsies (i.e., individual organ donations yielding multiple tissue sources) (Laurent et al., 2020b). There is high demand for large animal (e.g., horses or camels) innovative bioengineered therapeutic solutions in tissue reconstruction, which might be extrapolated from human regenerative medicine, due to strong similarities in respective wound healing processes (also see the "One Health Initiative") (Bigbie et al., 1991; Litzke et al., 2004; Carstanjen et al., 2006; Koch et al., 2009). Primary equine musculoskeletal FPCs were found to optimally and rapidly adapt to standardized bioprocessing and robust multi-tiered biobanking frameworks in view of optimized hippiatric medicine applications (i.e., tissue reconstruction and wound healing). Consistency, safety, and cytocompatibility were demonstrated with collagen and HA constructs, as well as the absence of immunogenicity or tumorigenicity in several case studies of reconstructive surgeries (Laurent et al., 2020b). Indeed, bioengineered equine PBBs (ePBB, formulated as magistral preparations) yielded efficient preliminary results in stimulating healing resurgence and stimulation of animal tissue repair. In particular, equine FPC therapies seemed to effectively stimulate epidermal and soft tissue regeneration, while limiting granulation tissue formation. Allogenic equine FPC therapy products derived from a single equine fetal organ donation may, therefore, be applied for the multifactorial translational musculoskeletal regenerative treatment of millions of veterinary patients in a safe, effective, and cost-effective manner (Laurent et al., 2020b).

\section{ITERATIVE OPTIMIZATION OF FPC BIOBANKING AND DRUG DELIVERY OPTIONS}

High clinical and regulatory pressure prompts iterative optimization of bioprocessing methods involving cell culture steps, mainly to replace animal-derived materials or substrates with defined products or consumables compatible with GMP manufacture, for safety and quality maximization (e.g., avoiding risk of contamination by transmissible spongiform encephalopathies in animal serum) (De Corte et al., 2012). Products such as Accutase ${ }^{\circledR}$ or TrypLE ${ }^{\mathrm{TM}}$ and Biofreeze ${ }^{\circledR}$, human serum albumin or sugar-based solutions have been proposed to replace porcine trypsin and DMSO-based cryopreservation media, respectively, and numerous producers tentatively develop serum-free culture media or HPL-based supplements, with variable results. The imperative nature of such changes must be relativized, as extensive industrial use of FBS has not yet yielded critical adverse effects. For industrial-scale manufacturing of cell bank lots, stringent optimization must be conducted regarding raw materials, reagents, and contact-process consumable selection. In particular, the make, model, and lot identity of culture vessels and nutrient supplements must be optimized by thorough benchmarking before use in a GMP environment, as these elements may bear significant impacts on endpoint cell yields or population doubling times, thereby tangibly affecting the overall cost of production (Laurent et al., 2020e). Novel culture vessel systems may be investigated for two-dimensional (e.g.) Corning ${ }^{\circledR}$ HYPERFlasks $^{\circledR}$, Nunc ${ }^{\mathrm{TM}}$ Cell Factories ${ }^{\mathrm{TM}}$, or Greiner CELLdiscs ${ }^{\mathrm{TM}}$ ) or three-dimensional (e.g., Terumo Quantum $^{\circledR}$, roller bottles, spinner flasks) cell culture efficiency, but should be thoroughly validated before adoption at industrial scales. Extensive optimization of polymeric biomaterials and novel biophysical processing methods continuously provide delivery scaffold options (i.e., inert, functionalized, or bioactive) for drug delivery of conjugated therapeutic cells. Acceptable cell survival and relative engraftment in vivo may be desired in specific applications, as wound environments adversely affect these parameters, due to anoikis, hypoxia, and local inflammatory effectors (Hyun et al., 2013). High resistance to oxidative stress, cryogenic shock, and physical constraints, such as shear stress, enable the effective coupling of primary FPCs with vast arrays of biomaterials, whereas, concerning cytocompatibility, the choice of therapeutic cell type often proves to be a major limiting factor ( $\mathrm{Ng}$ et al., 2004; De Buys Roessingh et al., 2006; Grognuz et al., 2016a). Importantly, future efforts in the development of therapeutic biological constructs will need to include ancillary, yet necessary, modalities of tissue reconstruction, such as anti-microbial factors to combat infectious complications (Abdel-Sayed et al., 2016; Valerio et al., 2016). In order to pursue continued product optimization and abolition of logistical dependency to cold chains, further biochemical or physical processing of therapeutic cellular materials may be implemented for integral cells or cell-free derivatives, in order to obtain preparations such as desiccated powders (e.g., lyophilizates) or semi-solid topical or injectable formulation (e.g., viscous hydrogels or creams) (Hirt-Burri et al., 2011; Lapp et al., 2013; Aldag et al., 2016; Grognuz et al., 2016a; Bari et al., 2019). For facilitated regulatory submissions, the combination of therapeutic cells should be considered with existing and marketed products, such as medical devices, benefiting from clinical validation. Such approaches, whenever possible, contribute to diminishing the validation efforts of novel TEPs and combination products such as combined advanced therapy medicinal products (cATMPs) in particular (Tenorio et al., 2011). Cell-scaffold interactions, creation of functional tissues, or absence of cytotoxicity and toxic by-products, must then be demonstrated, as well as biodegradability in specific cases (Hirt-Burri and Applegate, 2013; Jafari et al., 2017). Safety risks (i.e., immunogenicity or tumorigenicity) associated with the use of viable therapeutic cells (i.e., stem cells or FPCs) may be completely averted or mitigated by using devitalized cells or cellfree products (e.g., cell-based cell-free formulations). Alternative processing options for cell populations during cellular therapy or product manufacture comprise various physical (e.g., direct cryopreservation, lyophilization) or chemical processes (e.g., controlled lysis), resulting in devitalization and/or loss of cellular structural integrity, which may be followed by extraction or purification steps. Alternatively, conditioned media may be 
used for cell-free approaches. Devitalization or use of cell-free derivatives may be of considerable interest from a regulatory standpoint, as resulting therapies or products may be classified as cosmetics or medical devices, based on the nature of the intended effects and the relative importance of said effects (i.e., main or ancillary effects). Overall, tangible benefits favor the specific workflows of simultaneous and differential isolation of multiple FPC types from single fetal tissue donations, as culture initiation conditions are highly similar for all considered biopsies, may be controlled in parallel, and may be adjusted iteratively. Further optimization of FPC biobanking shall focus on epigenetics and influences of ethnic diversity on comparative efficiency for therapeutic product design or biotechnological manufacturing optimization.

\section{ETHICS, MORALS, RELIGION, AND POLITICS AROUND FPCS}

The unique approach of multiple-organ harvest following fetal organ donations, as practiced for adult solid organ transplantation, additionally restricts the need for multiple cell type isolation procedures. Technical or logistical availability of fetal tissue is theoretically not an issue, given the high relative rates of voluntary pregnancy termination in modern societies (e.g., six to nine terminations per 1,000 women in Switzerland over the past two decades) (Addor et al., 2003; Swiss Federal Statistical Office, 2019). In many countries including Switzerland, procurement of fetal tissue is classified as an organ donation and is highly regulated, as it requires Federal Authorities and Ethics Committee approvals (Applegate et al., 2009, 2010). Furthermore, regulated methodological aspects of Fetal Transplantation Programs and donor consent obtention ensure that related biomedical research does not increase either the number of pregnancy terminations nor the moral value thereof, and does not influence the termination date within the gestational period. Ethical examinations of programs seeking access to such fetal tissues embody a large place in the actual proceedings, whereas large variability exists in this respect throughout different countries and even between different states in Switzerland. Much like work with embryonic cells, the use of FPCs is deeply linked to moral questions, which are most prone to elicit debate. Depending on the technical availability of donated tissues, it is clear that some countries may not establish sufficient amounts of therapeutic treatments, but therapies or cell-based treatments may be imported, where they are allowed for use. In our own personal views, the whole-cell bioprocessing of fetal tissues for the establishment of primary FPC types, as described herein, might appear "unnatural" from conservative or strong religious standpoints. Nevertheless, this workflow requires minimal manipulation and ensures optimal conservation of initial tissue-specific biological characteristics for progeny cell populations. Such cell types therefore require relatively less human and biochemical intervention than phenotypically oriented MSCs or manipulated iPSCs, in order to obtain therapeutic cell populations or cell substrates fit for eventual clinical use.
It is also our personal belief that scientific and ethical advantages may be established around the use of fetal tissue or FPCs for therapeutic purposes, such as the potential medical benefits for millions of patients following one single organ donation, the restricted need for resorting to autograft harvest, and the respectful revalorization of high therapeutic value tissues otherwise destined for destruction. Considered clinical applications and therapeutic benefits resulting from the use of fetal organ donations may be quantified, and their weight may be clearly examined by appropriate regulatory and ethics bodies. Without the original fetal or embryonic cell lines established in the 20th century, many vaccines would not have been developed, potentially costing millions of lives. However, similarly to research on embryonic cells and despite the clear technical and clinical benefits from a scientific point of view, profound ethical and emotional aspects indirectly govern the practice of FPC therapy and the use of such substrates in the biotechnological industry (Lawler, 1981; Sanders et al., 1993; Rahman et al., 1998; Jost, 2002; Zimmerman, 2004; Greely, 2006; Panikkar et al., 2012). In particular, remarkable dissertations by the Catholic Church and Vatican-related groups extensively discuss the use of fetal cells from pregnancy terminations and applied for vaccine production, listing the "incriminated" products and companies and deeming the use of such materials as nuanced between and within the scope of "licit and illicit cooperation in Evil," under the influence of pharmaceutical companies and pertained to "social/medical moral coercion" (Furton, 1999; Maher et al., 2002; Pontifical Academy for Life, 2006). Interestingly, such positions are not maintained around the use of perinatal stem cells, as their exploitation for therapeutic purposes benefits from more leniency (Abbaspanah et al., 2018; Gaggi et al., 2019). On a political side, direct modulation of fetal cell research (i.e., including in vitro fertilization) has been achieved in the United States by cyclic restrictions on federal funding, with conservative positions aiming at banning such practices, while liberals have historically promoted women's health and freedom of choice, directly and indirectly benefiting medical progress (Manier, 2002). In a broader perspective, it is to note that perceived obstructionism to specific therapeutic cell source exploitation is not limited to religious or radical positions, as the US government has, through various and evolving polices, banned many aspects of research around ESCs for example, as this specific topic remains in heated debate (Murugan, 2009).

\section{LEGAL AND REGULATORY FRAMEWORKS FOR FPCs AND PRODUCT DEVELOPMENT}

Development and commercialization of therapies or cell-derived products are highly regulated in order to ensure safety and quality for the recipient. Respective regulatory landscapes and frameworks have been disruptively updated in Europe recently, creating labyrinthian procedures with mitigated outcomes on advances in the field of regenerative medicine, while potentially creating many regulatory pathway complications and deadlocks (Bertram et al., 2012; De Wilde et al., 2016; Dimitropoulos et al., 2016; Hartmann-Fritsch et al., 2016; Abdel-Sayed et al., 


\section{PROGENITOR CELLSS FOR REGENERATIVE MEDICINE}

A
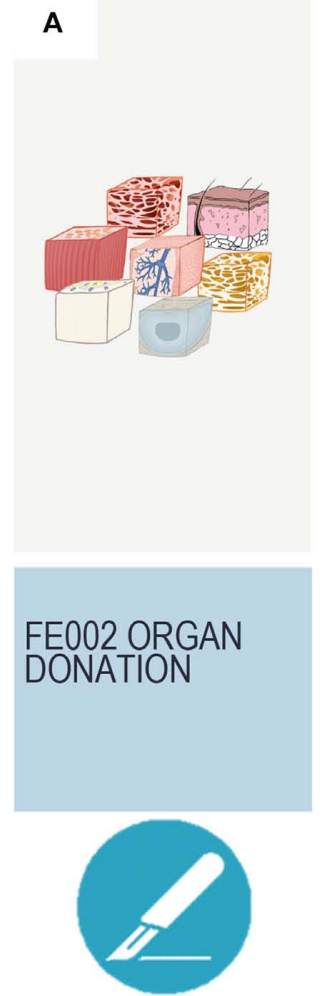

B

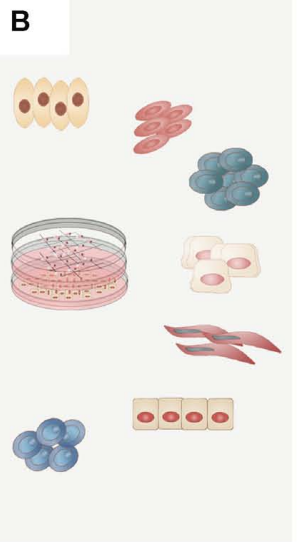

ALLOGENIC FE002 PROGENITOR CELLS

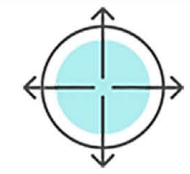

C
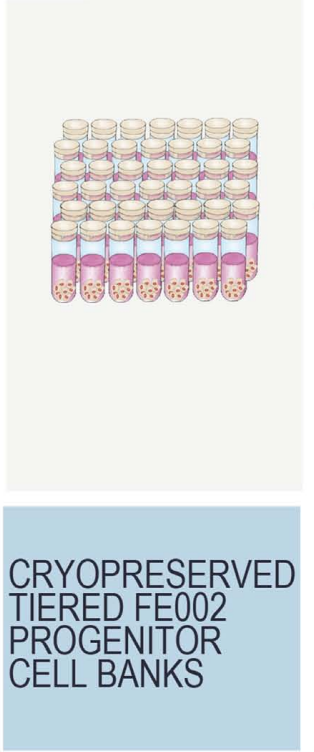

if

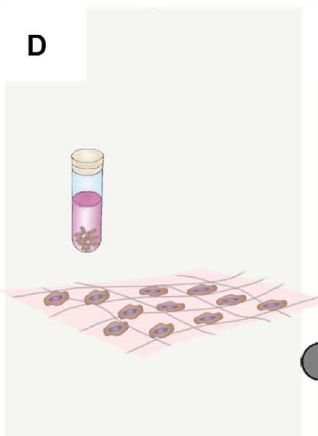

$E$
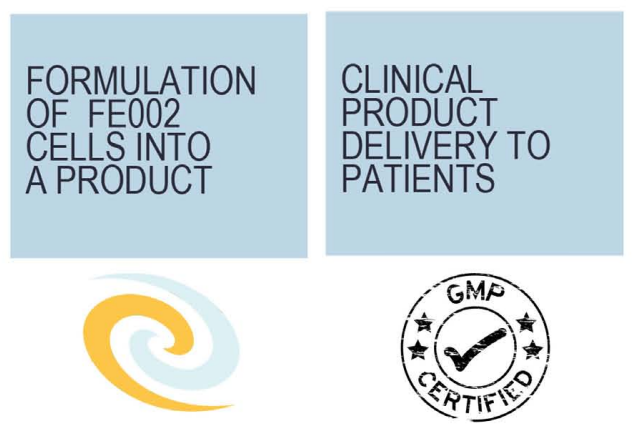

FIGURE 13 | Workflow schematic from initial fetal organ donation biopsy processing to FPC drug delivery to the patient within regenerative medicine settings. Following procurement of the FE002 donation (A) within the redefined regulatory framework (i.e., post-2007), tissue-specific allogenic primary FPC types were differentially and simultaneously derived (B), and used to constitute multi-tiered cryopreserved cell banks (C). In view of clinical delivery of therapeutic cells, appropriate vials may be initiated from storage and conjugated with adequate bioengineered scaffolds (D). The resulting constructs are standardized and safety is ensured by GMP processing from raw materials to final products. Following liberation, the products are transferred to the clinic for application on patients (E).

2019b). Bioengineered products (e.g., cell-laden scaffolds), as considered herein for primary FPC delivery, are classified as combined ATMPs or TEPs, implying inherent substantial manipulations for standardized transplant elaboration, for which GMP requirements are derived from classical pharmaceutical industry guidelines (Johnson et al., 2011; Fisher and Mauck, 2013; Esteban-Vives et al., 2018, 2019). Such dangerous or hampering constraints have limited and eventually reduced the number of products and therapies reaching the market in Europe and are particularly problematic for University Hospitals in particular, as local regulators enforce supranational regulatory frameworks often in detrimental or jeopardizing ways concerning historically used and clinically proven therapies (e.g., cultured autografts for burn patients) (Gallico et al., 1984; Gallico and O'Connor, 1985; Hickerson et al., 1994; Wood et al., 2006; Cirodde et al., 2011; Auxenfans et al., 2015; Eder and Wild, 2019; Laurent et al., 2020i). Faced with pharaonic costs of GMP manufacture and regulatory submissions burdening all public and private stakeholders, hospitals have developed differential approaches to implement in-house cell therapies (Gaspar and Swift, 2013; Cuende et al., 2014). Such undertakings were essential in order to comply with overarching legal frameworks, while continually providing the best therapies available to patients and conducting tangible innovative translational research for highly specialized medical applications. Such approaches of legal exposure mitigation comprise hospital exemptions, compassionate use, exceptional authorizations, orphan drug pathways, magistral or officinal preparations, possibly paving the way for the inclusion of cellbased therapies or cell/cell-derived APIs in official recognized repositories such as pharmacopeias (Pirnay et al., 2013, 2018; World Medical Association, 2013; Pearce et al., 2014; Dimitropoulos et al., 2016; Laurent et al., 2020i). Conjugation of high innovation and virtuosic interpretation of restrictively rigid or unharmonized legal and regulatory frameworks are current necessities, in order to ensure the progress of translational therapeutic developments for the benefit of patients worldwide. 


\section{PRECLINICAL AND CLINICAL APPLICATIONS OF FPCS IN SWITZERLAND TO DATE}

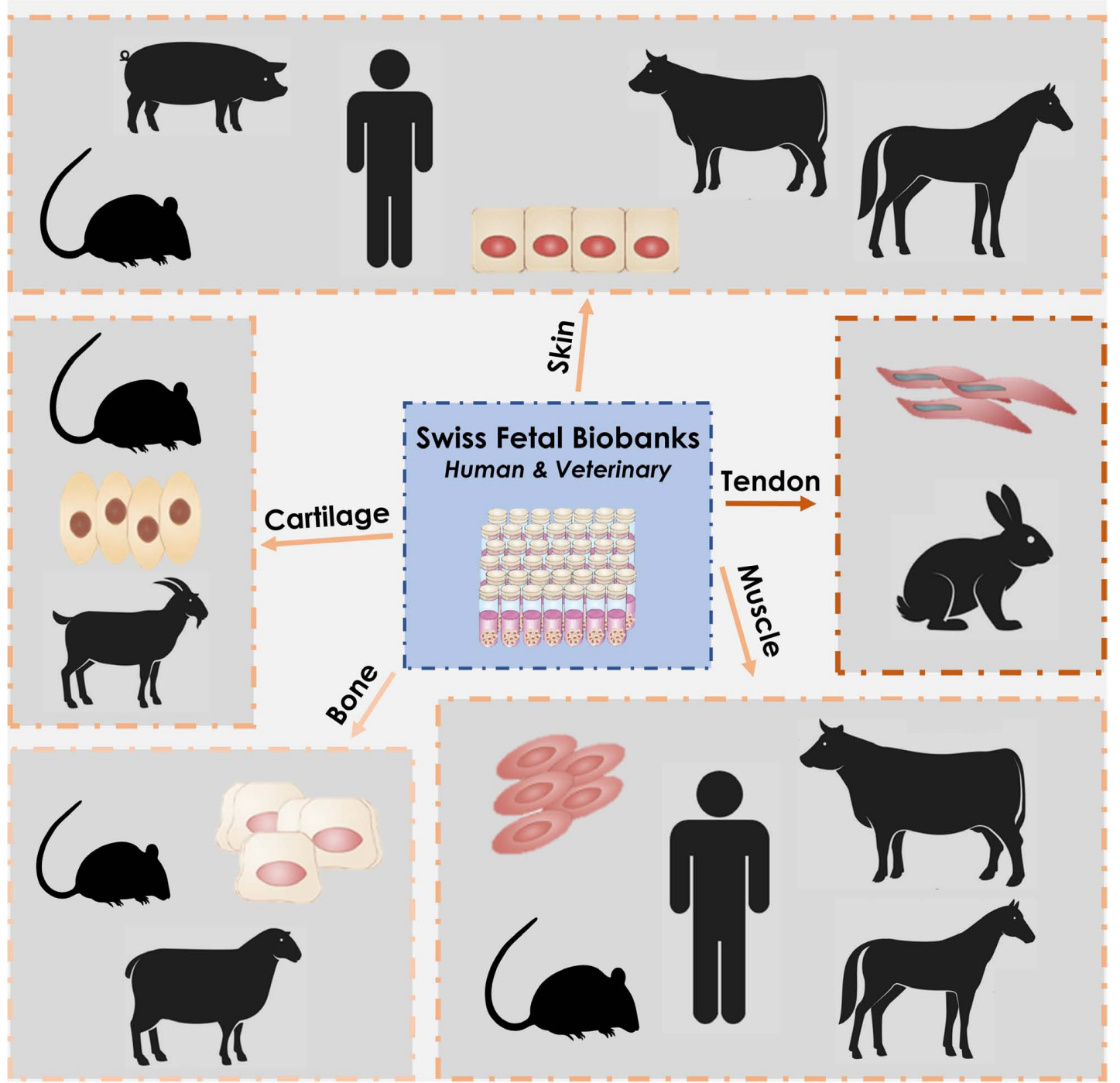

FIGURE 14 | General overview of in vivo experimentation and clinical applications of banked primary FPC types in Switzerland during the past two decades. Therapeutic cells constituted successive human Fetal Biobanks, as well as equine and ovine Fetal Biobanks. Therapeutic products comprised combined cell therapy products (i.e., PBBs, ePBBs, viable cells seeded in alternative polymeric scaffolds) or cosmeceutical/medical device-type semi-solid topical formulations of cell-free extracts (i.e., creams and hydrogels). Each FPC type is associated with the different models (i.e., human, porcine, murine, ovine, caprine, bovine, equine, lagomorph) which were part of preclinical investigations or clinically treated with FPCs or stabilized derivatives thereof. Accumulated clinical experience and hindsight attest to the absence of immunogenicity or tumorigenicity of mammalian FPCs, in their bio-integral, viable, or cell-free extract form, in both allogenic and defined xenogenic settings.

\section{GENERAL DISCUSSION}

The present work describes fundamental, preclinical, clinical, and industrial developments embodying the scientific advances supported by Swiss FPC banking. Such comprehensive reformulation and update of the past three decades of multidisciplinary work aimed to substantiate and convey interest, broadening awareness and use of standardized protocols for translational regenerative medicine, potentially impacting millions of patients suffering from cutaneous and musculoskeletal wounds and diseases. The high utility potential of recently derived primary FPC types (e.g., FE002$\mathrm{Lu}$ cell type) for biopharmaceutical therapeutic product manufacturing was also addressed, allowing for potential direct, indirect, and synergistic improvement of modern therapeutic armamentariums. The necessity for safe and consistent biological 
material sources is of paramount importance, in view of applicable regulatory, technical, and economic requirements existing within cell therapy product or biotechnological substrate development. In such regulated and defined contexts, optimization and standardization are of prime concern and should be the key steps in any translational workflows and manufacturing processes. Optimal management of safety and consistency of therapeutic cell sources is accomplished by avoiding pooling of numerous heterogeneous biological samples, and alternatively, exploiting sustainable multi-tiered FPC biobanks, simultaneously and differentially established after single fetal organ donations. Iterative therapeutic optimization and customized Fetal Transplantation Programs, enabling ethical and controlled biological material revalorization, have constituted the core innovative and developmental base for FPC therapy in Switzerland throughout three decades (Figure 1). Straightforward workflows were devised for tissue procurement, maximizing traceability, safety, consistency, and robustness of progeny cellular materials (Figures 68). The overall perception generated by translational work on FPC banking and transposition of related innovative biomedical technologies has comprehensively detailed the complexity of technical and therapeutic success obtention, which remains as a founding prerequisite in commercial product development. Banked FPCs have been historically used and thoroughly investigated throughout three decades in Switzerland, and have been deemed to adapt exceptionally well to specific therapeutic product developmental pathways. Extensive clinical experience has demonstrated the safety and usefulness of multiple primary FPC types to date. In the Lausanne University Hospital, pioneer contributions to innovative cutaneous regeneration solutions using dermal FPCs (e.g., FE002-SK2 cell type) have constituted the unified clinical flagship and eventual translational embodiment of the Swiss FPC Transplantation Program (Figures 9-12). These undertakings have yielded plethoric insights into the adequate conjugation of modern biotechnological innovation with current constraining legislative, ethical, and regulatory frameworks.

Transversal works on soft tissue and musculoskeletal FPC types of human and animal origin have provided diversified and differential insights into the potentials of FPC banking and supported further translational work in clinical testing and implementation. Most importantly, a single human fetal organ donation (i.e., FE002) qualifying for the Swiss Fetal Transplantation Program in 2009 yielded multiple unique FPC types (e.g., skin, cartilage, tendon, muscle, bone, and lung FPCs), validating the sustainable model of single donation for simultaneous differential organ harvest, subsequently presenting the quasi-infinite potential of applied research, clinical studies, and product development (Figures 7, 13). Widespread optimized and standardized sustainability constitute the core therapeutic value of FPC material sourcing and biobanking workflows supported herein, allowing the potential derivation of billions of affordable and efficient therapeutic product doses. As demonstrated herein by the comprehensive and detailed holistic approach of Swiss FPC biobanking technology, a single voluntary fetal organ donation is sufficient to support translational research encompassing the cutaneous and musculoskeletal systems for several decades (Figure 14 and Table 1). Further formulation and delivery system optimization, preclinical work, and clinical translation of therapies using FPCs will further enhance quality and efficiency of therapeutic care, benefiting overall health of patients worldwide.

\section{DATA AVAILABILITY STATEMENT}

The raw data supporting the conclusions of this article will be made available by the authors, without undue reservation.

\section{ETHICS STATEMENT}

The studies involving human participants were reviewed and approved by the CHUV University Hospital: State Ethics Committee. Written informed consent to participate in this study was provided by the participants' legal guardian/next of kin. Written informed consent was obtained from the individual(s) for the publication of any potentially identifiable images or data included in this article.

\section{AUTHOR CONTRIBUTIONS}

$\mathrm{AL}$ and LA: study conception and design. AL, CS, MM, and $\mathrm{NH}-\mathrm{B}$ : acquisition of data. $\mathrm{AL}$ and $\mathrm{NH}-\mathrm{B}$ : analysis and interpretation of data. AL, NH-B, MM, and LA: drafting of the manuscript. CS, NH-B, AB, WR, and LA: critical revision. $\mathrm{AL}, \mathrm{CS}, \mathrm{MM}, \mathrm{AD}, \mathrm{WR}, \mathrm{NH}-\mathrm{B}$, and LA: acceptance of final manuscript. All authors contributed to the article and approved the submitted version.

\section{FUNDING}

The S.A.N.T.E and Sandoz Foundations have contributed to funding the Swiss Fetal Progenitor Biobanking Program.

\section{ACKNOWLEDGMENTS}

This work was designed and carried out as an introductory outline for the industrial Ph.D. thesis in Life Sciences (Faculty of Biology and Medicine, University of Lausanne, Switzerland) of AL. We thank Mrs. Judith Applegate for her continued editorial work and Editage (www.editage.com) for English language editing of the manuscript. We would like to thank the S.A.N.T.E. and Sandoz Foundations for their commitments to the Swiss Fetal Progenitor Biobanking Program through the years.

\section{SUPPLEMENTARY MATERIAL}

The Supplementary Material for this article can be found online at: https://www.frontiersin.org/articles/10.3389/fbioe.2020. 557758/full\#supplementary-material 


\section{REFERENCES}

Abbasalizadeh, S., and Baharvand, H. (2013). Technological progress and challenges towards cGMP manufacturing of human pluripotent stem cells based therapeutic products for allogeneic and autologous cell therapies. Biotechnol. Adv. 31, 1600-1623. doi: 10.1016/j.biotechadv.2013.08.009

Abbasalizadeh, S., Pakzad, M., Cabral, J. M. S., and Baharvand, H. (2017). Allogeneic cell therapy manufacturing: Process development technologies and facility design options. Expert Opin. Biol. Ther. 17, 1201-1219. doi: 10.1080/ 14712598.2017.1354982

Abbaspanah, B., Momeni, M., Ebrahimi, M., and Mousavi, S. H. (2018). Advances in perinatal stem cells research: a precious cell source for clinical applications. Regen. Med. 13, 595-610. doi: 10.2217/rme-2018-0019

Abdel-Sayed, P., Darwiche, S. E., Kettenberger, U., and Pioletti, D. P. (2014). The role of energy dissipation of polymeric scaffolds in the mechanobiological modulation of chondrogenic expression. Biomaterials 35, 1890-1897. doi: 10. 1016/j.biomaterials.2013.11.048

Abdel-Sayed, P., Hirt-Burri, N., de Buys Roessingh, A. S., Raffoul, W., and Applegate, L. A. (2019a). Evolution of biological bandages as first cover for burn patients. Adv. Wound Care. 8, 555-564. doi: 10.1089/wound.2019.1037

Abdel-Sayed, P., Kaeppeli, A., Siriwardena, T., Darbre, T., Perron, K., Jafari, P., et al. (2016). Anti-microbial dendrimers against multidrug-resistant $P$. aeruginosa enhance the angiogenic effect of biological burn-wound bandages. Sci. Rep. 6:22020. doi: 10.1038/srep22020

Abdel-Sayed, P., Michetti, M., Scaletta, C., Flahaut, M., Hirt-Burri, N., de Buys Roessingh, A. S., et al. (2019b). Cell therapies for skin regeneration: An overview of 40 years of experience in burn units. Swiss Med. Wkly. 149:w20079. doi: 10.4414/smw.2019.20079

Acosta, F. L., Metz, L., Adkisson, H. D., Liu, J., Carruthers-Liebenberg, E., Milliman, C., et al. (2011). Porcine intervertebral disc repair using allogeneic juvenile articular chondrocytes or mesenchymal stem cells. Tissue Eng. Part A. 17, 3045-3055. doi: 10.1089/ten.tea.2011.0229

Addor, V., Narring, F., and Michaud, P. A. (2003). Abortion trends 1990-1999 in a Swiss region and determinants of abortion recurrence. Swiss Med. Wkly. 133, 219-226.

Adkisson, H. D., Martin, J. A., Amendola, R. L., Milliman, C., Mauch, K. A., Katwal, A. B., et al. (2010a). The potential of human allogeneic juvenile chondrocytes for restoration of articular cartilage. Am. J. Sports Med. 38, 1324-1333. doi: $10.1177 / 0363546510361950$

Adkisson, H. D., Milliman, C., Zhang, X., Mauch, K., Maziraz, R. T., and Streeter, P. R. (2010b). Immune evasion by neocartilage-derived chondrocytes: Implications for biologic repair of joint articular cartilage. Stem Cell Res. 4, 57-68. doi: 10.1016/j.scr.2009.09.004

Adzick, N. S., and Longaker, M. T. (1992). Scarless fetal healing. Therapeutic implications. Ann. Surg. 215, 3-7. doi: 10.1097/00000658-199201000-00004

Aeberhard, P. A., Grognuz, A., Peneveyre, C., McCallin, S., Hirt-Burri, N., Antons, J., et al. (2019). Efficient decellularization of equine tendon with preserved biomechanical properties and cytocompatibility for human tendon surgery indications. Artif. Organs. 00, 1-11. doi: 10.1111/aor.13581

Akershoek, J. J., Vlig, M., and Talhout, W. (2016). Cell therapy for full-thickness wounds: Are fetal dermal cells a potential source? Cell Tissue Res. 364, 83-94. doi: 10.1007/s00441-015-2293-6

Akhundov, K., Pietramaggiori, G., Waselle, L., Darwiche, S. E., Guerid, S., Scaletta, C., et al. (2012). Development of a cost-effective method for platelet-rich plasma (PRP) preparation for topical wound healing. Ann. Burns Fire Disasters 25, 207-213.

Akita, S., Akino, K., Imaizumi, T., and Hirano, A. (2008). Basic fibroblast growth factor accelerates and improves second-degree burn wound healing. Wound Repair Regen. 16, 635-641. doi: 10.1111/j.1524-475X.2008.00414.x

Aldag, C., Nogueira Teixeira, D., and Leventhal, P. S. (2016). Skin rejuvenation using cosmetic products containing growth factors, cytokines, and matrikines: A review of the literature. Clin Cosmet. Investig. Dermatol. 9, 411-419. doi: 10.2147/CCID.S116158

Almqvist, K. F., Dhollander, A. A., Verdonk, P. C., Forsyth, R., Verdonk, R., and Verbruggen, G. (2009). Treatment of cartilage defects in the knee using alginate beads containing human mature allogenic chondrocytes. Am. J. Sports Med. 37, 1920-1929. doi: 10.1177/0363546509335463
Alvarez-Barreto, J. F., Linehan, S. M., Shambaugh, R. L., and Sikavitsas, V. I. (2007). Flow perfusion improves seeding of tissue engineering scaffolds with different architectures. Ann. Biomed. Eng. 35, 429-442. doi: 10.1007/s10439-006-9244-z

Amani, H., Dougherty, W. R., and Blome-Eberwein, S. (2006). Use of TransCyte ${ }^{\circledR}$ and dermabrasion to treat burns reduces length of stay in burns of all size and etiology. Burns 32, 828-832. doi: 10.1016/j.burns.2006.04.003

Amini, A. R., Laurencin, C. T., and Nukavarapu, S. P. (2012). Bone tissue engineering: Recent advances and challenges. Crit. Rev. Biomed. Eng. 40, 363408. doi: 10.1615/critrevbiomedeng.v40.i5.10

Anderson, D. G., and Tannoury, C. (2005). Molecular pathogenic factors in symptomatic disc degeneration. Spine J. 5(6 Suppl.), 260S-266S. doi: 10.1016/j. spinee.2005.02.010

Applegate, L. A., Hirt-Burri, N., Scaletta, C., Bauen, J. F., Pioletti, D. P., Garcia, A., et al. (2010). "Bioengineering of human fetal tissues for clinical use," in Bioengineering: principles, metholdologies and applications, eds A. Garcia and C. Durand (New-York: Nova Science Publishers).

Applegate, L. A., Jafari, P., Scaletta, C., de Buys Roessingh, A. S., Raffoul, W., and Hirt-Burri, N. (2017). "Progenitor skin cell therapy and evolution of medical applications," in Alternatives for dermal toxicity testing, eds C. Eskes, E. van Vliet, and H. Maibach (Cham: Springer). doi: 10.1007/978-3-319-50353-0_40

Applegate, L. A., Scaletta, C., Hirt-Burri, N., Raffoul, W., and Pioletti, D. P. (2009). Whole-cell bioprocessing of human fetal cells for tissue engineering of skin. Skin Pharmacol. Physiol. 22, 63-73. doi: 10.1159/000178865

Applegate, L. A., Weber, D., Simon, J. P., Scaletta, C., Hirt-Burri, N., de Buys Roessingh, A. S., et al. (2013). "Organ donation and whole-cell bioprocessing in the Swiss fetal progenitor cell transplantation platform," in Organ Donation and Organ Donors, ed. R. F. Saidi (New York: Nova Science Publishers), 125-147.

Asahara, T., Murohara, T., Sullivan, A., Silver, M., van der Zee, R., Li, T., et al. (1997). Isolation of putative progenitor endothelial cells for angiogenesis. Science 275, 964-967. doi: 10.1126/science.275.5302.964

Aubin, J. E. (1998). Advances in the osteoblast lineage. Biochem. Cell Biol. 76, 899-910. doi: 10.1139/099-005

Auxenfans, C., Menet, V., Catherine, Z., and Shipkov, H. (2015). Cultured autologous keratinocytes in the treatment of large and deep burns: A retrospective study over 15 years. Burns 41, 71-79. doi: 10.1016/j.burns.2014. 05.019

Awad, H. A., Boivin, G. P., Dressler, M. R., Smith, F. N., Young, R. G., and Butler, D. L. (2003). Repair of patellar tendon injuries using a cell-collagen composite. J. Orthop. Res. 21, 420-431. doi: 10.1016/S0736-0266(02)00163-8

Bach, A. D., Arkudas, A., Tjiawi, J., Polykandriotis, E., Kneser, U., Horch, R. E., et al. (2006). A new approach to tissue engineering of vascularized skeletal muscle. J. Cell Mol. Med. 10, 716-726. doi: 10.1111/j.1582-4934.2006.tb00431.x

Banos, C. C., Thomas, A. H., and Kuo, C. K. (2008). Collagen fibrillogenesis in tendon development: Current models and regulation of fibril assembly. Birth Defects Res. C Embryo Today 84, 228-244. doi: 10.1002/bdrc.20130

Bari, E., Perteghella, S., Catenacci, L., Sorlini, M., Croce, S., Mantelli, M., et al. (2019). Freeze-dried and GMP-compliant pharmaceuticals containing exosomes for acellular mesenchymal stromal cell immunomodulant therapy. Nanomedicine 14, 753-765. doi: 10.2217/nnm-2018-0240

Barrientos, S., Stojadinovic, O., Golinko, M. S., Brem, H., and Tomic-Canic, M. (2008). Growth factors and cytokines in wound healing. Wound Repair Regen. 16, 585-601. doi: 10.1111/j.1524-475X.2008.00410.x

Bartholomew, A., Sturgeon, C., Siatskas, M., Ferrer, K., McIntosh, K., Patil, S., et al. (2002). Mesenchymal stem cells suppress lymphocyte proliferation in vitro and prolong skin graft survival in vivo. Exp. Hematol. 30, 42-48. doi: 10.1016/s0301$472 x(01) 00769-x$

Beauchamp, J. R., Morgan, J. E., Pagel, C. N., and Partridge, T. A. (1999). Dynamics of myoblast transplantation reveal a discrete minority of precursors with stem cell-like properties as the myogenic source. J. Cell Biol. 144, 1113-1122. doi: 10.1083/jcb.144.6.1113

Beauchamp, J. R., Pagel, C. N., and Partridge, T. A. (1997). A dual-marker system for quantitative studies of myoblast transplantation in the mouse. Transplantation 63, 1794-1797. doi: 10.1097/00007890-199706270-00015

Beredjiklian, P. K., Favata, M., Cartmell, J. S., Flanagan, C. L., Crombleholme, T. M., and Soslowsky, L. J. (2003). Regenerative versus reparative healing in tendon: A study of biomechanical and histological properties in fetal sheep. Ann. Biomed. Eng. 31, 1143-1152. doi: 10.1114/1.1616931 
Bertram, T. A., Tentoff, E., Johnson, P. C., and Tawil, B. (2012). Hurdles in tissue engineering/regenerative medicine product commercialization: A pilot survey of governmental funding agencies and the financial industry. Tissue Eng. Part A. 18, 2187-2194. doi: 10.1089/ten.TEA.2012.0186

Bhattacharya, N. (2004). Fetal cell/tissue therapy in adult disease: A new horizon in regenerative medicine. Clin. Exp. Obstet. Gynecol. 31, 167-173.

Bianco, P., Riminucci, M., Gronthos, S., and Robey, P. G. (2001). Bone marrow stromal stem cells: Nature, biology, and potential applications. Stem Cells 19, 180-192. doi: 10.1634/stemcells.19-3-180

Bigbie, R. B., Schumacher, J., Swaim, S. F., Purohit, R. C., and Wright, J. C. (1991). Effects of amnion and live yeast cell derivative on second-intention healing in horses. Am. J. Vet. Res. 52, 1376-1382.

Boerckel, J. D., Kolambkar, Y. M., Stevens, H. Y., Lin, A. S., Dupont, K. M., and Guldberg, R. E. (2012). Effects of in vivo mechanical loading on large bone defect regeneration. J. Orthop. Res. 30, 1067-1075. doi: 10.1002/jor.22042

Borcard, F., Godinat, A., Staedler, D., Blanco, H. C., Dumont, A. L., ChapuisBernasconi, C., et al. (2011). Covalent cell surface functionalization of human fetal osteoblasts for tissue engineering. Bioconjug. Chem. 22, 1422-1432. doi: $10.1021 /$ bc $200147 \mathrm{~m}$

Borcard, F., Staedler, D., Comas, H., Juillerat, F. K., Sturzenegger, P. N., Heuberger, R., et al. (2012). Chemical functionalization of bioceramics to enhance endothelial cells adhesion for tissue engineering. J. Med. Chem. 55, 7988-7997. doi: $10.1021 /$ jm $301092 \mathrm{r}$

Brittberg, M., Lindahl, A., Nilsson, A., Ohlsson, C., Isaksson, O., and Peterson, L. (1994). Treatment of deep cartilage defects in the knee with autologous chondrocyte transplantation. N. Engl. J. Med. 331, 889-895. doi: 10.1056/ NEJM199410063311401

Broguiere, N., Cavalli, E., Salzmann, G. M., Applegate, L. A., and Zenobi-Wong, M. (2016). Factor XIII cross-linked hyaluronan hydrogels for cartilage tissue engineering. ACS Biomater Sci. Eng. 2, 2176-2184. doi: 10.1021/acsbiomaterials. $6 \mathrm{~b} 00378$

Bullard, K. M., Longaker, M. T., and Lorenz, H. P. (2003). Fetal wound healing: Current biology. World J. Surg. 27, 54-61. doi: 10.1007/s00268-002-6737-2

Burg, K. J., Holder, W. D. Jr., Culberson, C. R., Beiler, R. J., Greene, K. G., Loebsack, A. B., et al. (2000). Comparative study of seeding methods for threedimensional polymeric scaffolds. J Biomed. Mater Res. 51, 642-649. doi: 10. 1002/1097-4636(20000915)51:4<642::aid-jbm12<3.0.co;2-1

Burk, J., Plenge, A., Brehm, W., Heller, S., Pfeiffer, B., and Kasper, C. (2016). Induction of tenogenic differentiation mediated by extracellular tendon matrix and short-term cyclic stretching. Stem Cells Int. 2016:7342379. doi: 10.1155/ 2016/7342379

Campbell, J. J., Lee, D. A., and Bader, D. L. (2006). Dynamic compressive strain influences chondrogenic gene expression in human mesenchymal stem cells. Biorheology 43, 455-470.

Capes-Davis, A., Theodosopoulos, G., Atkin, I., Drexler, H. G., Kohara, A., MacLeod, R. A., et al. (2010). Check your cultures! A list of cross-contaminated or misidentified cell lines. Int. J. Cancer 127, 1-8. doi: 10.1002/ijc.25242

Caplan, A. I., and Goldberg, V. M. (1999). Principles of tissue engineered regeneration of skeletal tissues. Clin. Orthop. Relat. Res. 367, S12-S16. doi: 10.1097/00003086-199910001-00003

Cardinale, V., Carpino, G., Gentile, R., Napoletano, C., Rahimi, H., Franchitto, A., et al. (2014). Transplantation of human fetal biliary tree stem/progenitor cells into two patients with advanced liver cirrhosis. BMC Gastroenterol. 14:204. doi: 10.1186/s12876-014-0204-z

Carluccio, S., Martinelli, D., Palamà, M., Pereira, R. C., Benelli, R., Guijarro, A., et al. (2020). Progenitor cells activated by platelet lysate in human articular cartilage as a tool for future cartilage engineering and reparative strategies. Cells 9:1052. doi: 10.3390/cells9041052

Carosella, E. D., Moreau, P., Lemaoult, J., and Rouas-Freiss, N. (2008). HLA-G: From biology to clinical benefits. Trends Immunol. 29, 125-132. doi: 10.1016/j. it.2007.11.005

Carstanjen, B., Desbois, C., Hekmati, M., and Behr, L. (2006). Successful engraftment of cultured autologous mesenchymal stem cells in a surgically repaired soft palate defect in an adult horse. Can. J. Vet. Res. 70, 143-147.

Carter, D. R., Orr, T. E., and Fyhrie, D. P. (1989). Relationships between loading history and femoral cancellous bone architecture. J. Biomech. 22, 231-244. doi: 10.1016/0021-9290(89)90091-2
Cass, D. L., Bullard, K. M., Sylvester, K. G., Yang, E. Y., Longaker, M. T., and Adzick, N. S. (1997). Wound size and gestational age modulate scar formation in fetal wound repair. J. Pediatr. Surg. 32, 411-415. doi: 10.1016/s0022-3468(97) 90593-5

Cavalli, E., Fisch, P., Formica, F. A., Gareus, R., Linder, T., Applegate, L. A., et al. (2018). A comparative study of cartilage engineered constructs in immunocompromised, humanized and immunocompetent mice. J. Immunol. Regen. Med. 2, 36-46. doi: 10.1016/j.regen.2018.09.001

Chen, X., Song, X. H., Yin, Z., Zou, X. H., Wang, L. L., Hu, H., et al. (2009). Stepwise differentiation of human embryonic stem cells promotes tendon regeneration by secreting fetal tendon matrix and differentiation factors. Stem Cells 27, 1276-1287. doi: 10.1002/stem.61

Chiba, K., Andersson, G. B., Masuda, K., and Thonar, E. J. (1997). Metabolism of the extracellular matrix formed by intervertebral disc cells cultured in alginate. Spine 22, 2885-2893. doi: 10.1097/00007632-199712150-00011

Chong, A. K., Riboh, J., Smith, R. L., Lindsey, D. P., Pham, H. M., and Chang, J. (2009). Flexor tendon tissue engineering: Acellularized and reseeded tendon constructs. Plast. Reconstr. Surg. 123, 1759-1766. doi: 10.1097/PRS. 0b013e3181a65ae7

Ciciliot, S., and Schiaffino, S. (2010). Regeneration of mammalian skeletal muscle. Basic mechanisms and clinical implications. Curr. Pharm. Des. 16, 906-914. doi: $10.2174 / 138161210790883453$

Cirodde, A., Leclerc, T., Jault, P., and Duhamel, P. (2011). Cultured epithelial autografts in massive burns: A single-center retrospective study with 63 patients. Burns 37, 964-972. doi: 10.1016/j.burns.2011.03.011

Clarkson, E. D. (2001). Fetal tissue transplantation for patients with Parkinson's disease: A database of published clinical results. Drugs Aging 18, 773-785. doi: 10.2165/00002512-200118100-00006

Climov, M., Panayi, A. C., Borah, G., and Orgill, D. P. (2020). The life-cycles of skin replacement technologies. PloS One 15:e0229455. doi: 10.1371/journal.pone. 0229455

Comas, H., Laporte, V., Borcard, F., Miéville, P., Krauss Juillerat, F., Caporini, M. A., et al. (2012). Surface functionalization of alumina ceramic foams with organic ligands. ACS Appl. Mater Interf. 4, 573-576. doi: 10.1021/am201638a

Costa-Almeida, R., Calejo, I., and Gomes, M. E. (2019). Mesenchymal stem cells empowering tendon regenerative therapies. Int. J. Mol. Sci. 20:3002. doi: 10. 3390/ijms20123002

Crevensten, G., Walsh, A. J., Ananthakrishnan, D., Page, P., Wahba, G. M., Lotz, J. C., et al. (2004). Intervertebral disc cell therapy for regeneration: Mesenchymal stem cell implantation in rat intervertebral discs. Ann. Biomed. Eng. 32, 430-434. doi: 10.1023/b:abme.0000017545.84833.7c

Crombleholme, T. M., Langer, J. C., Harrison, M. R., and Zanjani, E. D. (1991). Transplantation of fetal cells. Am. J. Obstet. Gynecol. 164(Pt 1), 218-230. doi: 10.1016/0002-9378(91)90656-c

Cuende, N., Boniface, C., Bravery, C., Forte, M., Giordano, R., Hildebrandt, M., et al. (2014). The puzzling situation of hospital exemption for advanced therapy medicinal products in Europe and stakeholders' concerns. Cryotherapy 16, 1597-1600. doi: 10.1016/j.jcyt.2014.08.007

Dang, C., Ting, K., Soo, C., Longaker, M. T., and Lorenz, H. P. (2003). Fetal wound healing current perspectives. Clin. Plast. Surg. 30, 13-23. doi: 10.1016/s00941298(02)00067-6

Darwiche, S. E., Scaletta, C., Raffoul, W., Pioletti, D. P., and Applegate, L. A. (2012). Epiphyseal chondroprogenitors provide a stable cell source for cartilage cell therapy. Cell Med. 4, 23-32. doi: 10.3727/215517912X639324

De Buys Roessingh, A. S., Guerid, S., Que, Y., Berger, M., Hirt-Burri, N., Scaletta, C., et al. (2013). Cell therapy assistance in reconstructive surgery for musculoskeletal tissues following burn and trauma: Swiss cellular transplantation platform. Def. Manag. S 3:003. doi: 10.4172/2167-0374.S3-003

De Buys Roessingh, A. S., Hirt-Burri, N., Raffoul, W., Scaletta, C., and Applegate, L. A. (2015). A decade after foetal skin progenitor cell therapy in pediatric burn treatment. J. Regen. Med. 4:1. doi: 10.4172/2325-9620.1000122

De Buys Roessingh, A. S., Hohlfeld, J., Scaletta, C., Hirt-Burri, N., Gerber, S., Hohlfeld, P., et al. (2006). Development, characterization, and use of a fetal skin cell bank for tissue engineering in wound healing. Cell Transpl. 15, 823-834. doi: 10.3727/000000006783981459

De Corte, P., Verween, G., Verbeken, G., and Rose, T. (2012). Feeder-layerand animal product-free culture of neonatal foreskin keratinocytes: Improved 
performance, usability, quality and safety. Cell Tissue Bank 13, 175-189. doi: 10.1007/s10561-011-9247-3

De Wilde, S., Veltrop-Duits, L., Hoozemans-Strik, M., Ras, T., and Blom-Veenman, J. (2016). Hurdles in clinical implementation of academic Advanced Therapy Medicinal Product: A national evaluation. Cythotherapy 18, 797-805. doi: 10. 1016/j.jcyt.2016.02.010

Debels, H., Hamdi, M., and Abberton, K. (2015). Dermal matrices and bioengineered skin substitutes: A critical review of current options. Plast. Reconstr. Surg. Glob. Open 3:e284. doi: 10.1097/GOX.0000000000000219

Decary, S., Mouly, V., Hamida, C. B., Sautet, A., Barbet, J. P., and Butler-Browne, G. S. (1997). Replicative potential and telomere length in human skeletal muscle: Implications for satellite cell-mediated gene therapy. Hum. Gene. Ther 8, 1429-1438. doi: 10.1089/hum.1997.8.12-1429

Déglise, B., Benathan, M., Frenk, E., and Krupp, S. (1987). Preliminary results of burn treatment using an autograft of cultured epidermis. Schweiz. Med. Wochenschr. 117, 1380-1383.

Deschaseaux, F., Delgado, D., Pistoia, V., Giuliani, M., Morandi, F., and Durrbach, A. (2011). HLA-G in organ transplantation: Towards clinical applications. Cell Mol. Life Sci. 68, 397-404. doi: 10.1007/s00018-010-0581-6

Dhollander, A. A., Verdonk, P. C., Lambrecht, S., Verdonk, R., Elewaut, D., Verbruggen, G., et al. (2012). Midterm results of the treatment of cartilage defects in the knee using alginate beads containing human mature allogenic chondrocytes. Am. J. Sports Med. 40, 75-82. doi: 10.1177/0363546511423013

Dimitropoulos, G., Jafari, P., de Buys Roessingh, A. S., Hirt-Burri, N., and Raffoul, W. (2016). Burn patient care lost in Good Manufacturing Practices? Ann. Burns Fire Disast. 29, 111-115.

Docheva, D., Hunziker, E. B., Fässler, R., and Brandau, O. (2005). Tenomodulin is necessary for tenocyte proliferation and tendon maturation. Mol. Cell Biol. 25, 699-705. doi: 10.1128/MCB.25.2.699-705.2005

Doyle, A., and Griffiths, J. B. (1998). Cell and Tissue Culture: Laboratory Procedures in Biotechnology. New York, USA: Wiley \& Sons.

Drury, J. L., and Mooney, D. J. (2003). Hydrogels for tissue engineering: Scaffold design variables and applications. Biomaterials 24, 4337-4351. doi: 10.1016/ s0142-9612(03)00340-5

Ducheyne, P., and Qiu, Q. (1999). Bioactive ceramics: The effect of surface reactivity on bone formation and bone cell function. Biomaterials 20, 22872303. doi: 10.1016/s0142-9612(99)00181-7

Duffy, R. M., Sun, Y., and Feinberg, A. W. (2016). Understanding the role of ECM protein composition and geometric micropatterning for engineering human skeletal muscle. Ann. Biomed. Eng. 44, 2076-2089. doi: 10.1007/s10439-0161592-8

Eder, C., and Wild, C. (2019). Technology forecast: Advanced therapies in late clinical research, EMA approval or clinical application via hospital exemption. J. Mark Access. Health Policy 7:1600939. doi: 10.1080/20016689.2019.160 0939

Erickson, I. E., Kestle, S. R., Zellars, K. H., Farrell, M. J., Kim, M., Burdick, J. A., et al. (2012). High mesenchymal stem cell seeding densities in hyaluronic acid hydrogels produce engineered cartilage with native tissue properties. Acta Biomater 8, 3027-3034. doi: 10.1016/j.actbio.2012. 04.033

Esteban-Vives, R., Corcos, A., Choi, M. S., and Young, M. T. (2018). Cellspray auto-grafting technology for deep partial-thickness burns: Problems and solutions during clinical implementation. Burns 44, 549-559. doi: 10.1016/j. burns.2017.10.008

Esteban-Vives, R., Ziembicki, J., Choi, M. S., and Thompson, R. L. (2019). Isolation and characterization of a human fetal mesenchymal stem cell population: Exploring the potential for cell banking in wound healing therapies. Cell Transpl. 28, 1404-1419. doi: 10.1177/0963689718817524

Fan, Y., Maley, M., Beilharz, M., and Grounds, M. (1996). Rapid death of injected myoblasts in myoblast transfer therapy. Musc. Nerve 19, 853-860. doi: 10.1002/ (SICI) 1097-4598(199607)19:7<853::AID-MUS7<3.0.CO;2-8

Favata, M., Beredjiklian, P. K., Zgonis, M. H., Beason, D. P., Crombleholme, T. M., Jawad, A. F., et al. (2006). Regenerative properties of fetal sheep tendon are not adversely affected by transplantation into an adult environment. J. Orthop. Res. 24, 2124-2132. doi: 10.1002/jor.20271

Fisher, M. B., and Mauck, R. L. (2013). Tissue engineering and regenerative medicine: Recent innovations and the transition to translation. Tissue Eng. Part B. 19, 1-13. doi: 10.1089/ten.TEB.2012.0723
Fitzpatrick, R. E., and Rostan, E. F. (2003). Reversal of photodamage with topical growth factors: A pilot study. J. Cosmet. Laser Ther. 5, 25-34. doi: 10.1080/ 14764170310000817

Flanigan, D. C., Harris, J. D., Trinh, T. Q., Siston, R. A., and Brophy, R. H. (2010). Prevalence of chondral defects in athletes' knees: A systematic review. Med. Sci. Sports Exerc. 42, 1795-1801. doi: 10.1249/MSS.0b013e3181d9eea0

Foglia, R. P., DiPreta, J., Statter, M. B., and Donahoe, P. K. (1986). Fetal allograft survival in immunocompetent recipients is age dependent and organ specific. Ann. Surg. 204, 402-410. doi: 10.1097/00000658-198610000-00008

Franceschi, R. T. (1999). The developmental control of osteoblast-specific gene expression: Role of specific transcription factors and the extracellular matrix environment. Crit. Rev. Oral Biol. Med. 10, 40-57. doi: 10.1177/ 10454411990100010201

Freeman, T. B. (1997). From transplants to gene therapy for Parkinson's disease. Exp. Neurol. 144, 47-50. doi: 10.1006/exnr.1996.6387

Furton, E. J. (1999). Vaccines origination in abortion. Ethics Medics 24, 3-4.

Gabbianelli, M., Sargiacomo, M., Pelosi, E., Testa, U., Isacchi, G., and Peschle, C. (1990). "Pure" human hematopoietic progenitors: Permissive action of basic fibroblast growth factor. Science 249, 1561-1564. doi: 10.1126/science.2218497

Gaggi, G., Izzicupo, P., Di Credico, A., Sancilio, S., Di Baldassarre, A., and Ghinassi, B. (2019). Spare parts from discarded materials: Fetal annexes in regenerative medicine. Int. J. Mol. Sci. 20:1573. doi: 10.3390/ijms20071573

Gallagher, J. A. (2003). Human osteoblast culture. Methods Mol. Med. 80, 3-18. doi: $10.1385 / 1-59259-366-6: 3$

Gallico, G. G., and O'Connor, N. E. (1985). Cultured epithelium as a skin substitute. Clin. Plast. Surg. 12, 149-157. doi: 10.1016/S0094-1298(20)31686-2

Gallico, G. G., O’Connor, N. E., Compton, C. C., and Kehinde, O. (1984). Permanent coverage of large burn wounds with autologous cultured human epithelium. N Engl. J. Med. 311, 448-451. doi: 10.1056/NEJM198408163110706

Ganey, T., Libera, J., Moos, V., Alasevic, O., Fritsch, K. G., Meisel, H. J., et al. (2003). Disc chondrocyte transplantation in a canine model: A treatment for degenerated or damaged intervertebral disc. Spine 28, 2609-2620. doi: 10.1097/ 01.BRS.0000097891.63063.78

Gaspar, B., and Swift, S. (2013). 'Special Exemptions': Should they be put on trial? Mol. Ther. 21, 261-262. doi: 10.1038/mt.2013.1

Glantz, L., Roche, P., and Annas, G. J. (2008). Rules for donations to tissue banks-What next? N. Engl. J. Med. 358, 298-303. doi: 10.1056/NEJMhle074597

Gold, M. H., and Biron, J. (2006). A novel skin cream containing a mixture of human growth factors and cytokines for the treatment of adverse events associated with photodynamic therapy. J. Drugs Dermatol. 5, 796-798.

Gold, M. H., Goldman, M. P., and Biron, J. (2007). Efficacy of novel skin cream containing mixture of human growth factors and cytokines for skin rejuvenation. J. Drugs Dermatol. 6, 197-201.

Grasman, J. M., Zayas, M. J., Page, R. L., and Pins, G. D. (2015). Biomimetic scaffolds for regeneration of volumetric muscle loss in skeletal muscle injuries. Acta Biomater 25, 2-15. doi: 10.1016/j.actbio.2015.07.038

Greely, H. T. (2006). Moving human embryonic stem cells from legislature to lab: remaining legal and ethical questions. PLoS Med. 3, 571-575. doi: 10.1371/ journal.pmed.0030143

Gridelli, B., Vizzini, G., Pietrosi, G., Luca, A., Spada, M., Gruttadauria, S., et al. (2012). Efficient human fetal liver cell isolation protocol based on vascular perfusion for liver cell-based therapy and case report on cell transplantation. Liver Transpl. 18, 226-237. doi: 10.1002/lt.22322

Griffith, L. G., and Naughton, G. (2002). Tissue engineering-current challenges and expanding opportunities. Science 295, 1009-1014. doi: 10.1126/science. 1069210

Grogan, B. F., Hsu, J. R., and Skeletal Trauma Research Consortium. (2011). Volumetric muscle loss. J. Am. Acad. Orthop. Surg. 19(Suppl. 1), S35-S37. doi: 10.5435/00124635-201102001-00007

Grognuz, A., Aeberhard, P. A., Michetti, M., Hirt-Burri, N., Scaletta, C., de Buys Roessingh, A. S., et al. (2019). "Cell therapies for tendon: Treatments and regenerative medicine," in Regenerative Medicine and Plastic Surgery, eds D. Duscher and M. Shiffman (Cham: Springer). doi: 10.1007/978-3-030-199623_27

Grognuz, A., Scaletta, C., Farron, A., Pioletti, D. P., Raffoul, W., and Applegate, L. A. (2016a). Stability enhancement using hyaluronic acid gels for delivery of human fetal progenitor tenocytes. Cell Med. 8, 87-97. doi: 10.3727/ 215517916 X690486 
Grognuz, A., Scaletta, C., Farron, A., Raffoul, W., and Applegate, L. A. (2016b). Human fetal progenitor tenocytes for regenerative medicine. Cell Transpl. 25, 463-479. doi: 10.3727/096368915X688515

Gronthos, S., Chen, S., Wang, C. Y., Robey, P. G., and Shi, S. (2003). Telomerase accelerates osteogenesis of bone marrow stromal stem cells by upregulation of CBFA1, osterix, and osteocalcin. J. Bone Miner Res. 18, 716-722. doi: 10.1359/ jbmr.2003.18.4.716

Guérette, B., Skuk, D., Célestin, F., Huard, C., Tardif, F., Asselin, I., et al. (1997). Prevention by anti-LFA-1 of acute myoblast death following transplantation. J. Immunol. 159, 2522-2531.

Guerid, S., Darwiche, S. E., Berger, M. M., Applegate, L. A., Benathan, M., and Raffoul, W. (2013). Autologous keratinocyte suspension in platelet concentrate accelerates and enhances wound healing - A prospective randomized clinical trial on skin graft donor sites: Platelet concentrate and keratinocytes on donor sites. Fibrogenesis Tissue Repair 6:8. doi: 10.1186/1755-1536-6-8

Haack-Sørensen, M., and Kastrup, J. (2011). Cryopreservation and revival of mesenchymal stromal cells. Methods Mol. Biol. 698, 161-174. doi: 10.1007/9781-60761-999-4_13

Habibullah, C. M., Syed, I. H., Qamar, A., and Taher-Uz, Z. (1994). Human fetal hepatocyte transplantation in patients with fulminant hepatic failure. Transplantation 58, 951-952. doi: 10.1097/00007890-199410270-00016

Haefeli, M., Kalberer, F., Saegesser, D., Nerlich, A. G., Boos, N., and Paesold, G. (2006). The course of macroscopic degeneration in the human lumbar intervertebral disc. Spine 31, 1522-1531. doi: 10.1097/01.brs.0000222032. $52336.8 \mathrm{e}$

Hartmann, B., Ekkernkamp, A., Johnen, C., Gerlach, J. C., Belfekroun, C., and Küntscher, M. V. (2007). Sprayed cultured epithelial autografts for deep dermal burns of the face and neck. Ann. Plast. Surg. 58, 70-73. doi: 10.1097/01.sap. 0000250647.39784.bb

Hartmann-Fritsch, F., Marino, D., and Reichmann, E. (2016). About ATMPs, SOPs and GMP: The hurdles to produce novel skin grafts for clinical use. Transfus. Med. Hemother. 43, 344-352. doi: 10.1159/000447645

Hasegawa, T., Miwa, M., Sakai, Y., Niikura, T., Lee, S. Y., Oe, K., et al. (2010). Efficient cell-seeding into scaffolds improves bone formation. J. Dent. Res. 89, 854-859. doi: 10.1177/0022034510370022

Häuselmann, H. J., Fernandes, R. J., Mok, S. S., Schmid, T. M., Block, J. A., Aydelotte, M. B., et al. (1994). Phenotypic stability of bovine articular chondrocytes after long-term culture in alginate beads. J. Cell Sci. 107(Pt 1), 17-27.

Hausherr, T. C., Nuss, K., Thein, E., Applegate, L. A., and Pioletti, D. P. (2017). Human bone progenitor cells for clinical application: What kind of immune reaction does fetal xenograft tissue trigger in immunocompetent rats? Cell Transpl. 26, 879-890. doi: 10.3727/096368916X693789

Hausherr, T. C., Nuss, K., Thein, E., Krähenbühl, S., Applegate, L. A., and Pioletti, D. P. (2018). Effect of temporal onsets of mechanical loading on bone formation inside a tissue engineering scaffold combined with cell therapy. Bone Rep. 8, 173-179. doi: 10.1016/j.bonr.2018.04.008

Hayflick, L., Plotkin, S. A., Norton, T. W., and Koprowski, H. (1962). Preparation of poliovirus vaccines in a human fetal diploid cell strain. Am. J. Hyg. 75, 240-258. doi: 10.1093/oxfordjournals.aje.a120247

Heathman, T. R., Nienow, A. W., McCall, M. J., Coopman, K., Kara, B., and Hewitt, C. J. (2015). The translation of cell-based therapies: Clinical landscape and manufacturing challenges. Regen. Med. 10, 49-64. doi: 10.2217/rme.14.73

Hebda, P. A., and Dohar, J. E. (1999). Transplanted fetal fibroblasts: Survival and distribution over time in normal adult dermis compared with autogenic, allogenic, and xenogenic adult fibroblasts. Otolaryngol. Head Neck Surg. 121, 245-251. doi: 10.1016/S0194-5998(99)70179-8

Hickerson, W. L., Compton, C., Fletchall, S., and Smith, L. R. (1994). Cultured epidermal autografts and allodermis combination for permanent burn wound coverage. Burns 20, S52-S56. doi: 10.1016/0305-4179(94)90091-4

Hirt-Burri, N., and Applegate, L. A. (2013). "Fetal cell therapy and tissue engineering for musculoskeletal tissues," in Human Fetal Tissue Transplantation, eds N. Bhattacharya and P. Stubblefield (London: Springer). doi: 10.1007/978-1-4471-4171-6_14

Hirt-Burri, N., de Buys Roessingh, A. S., Scaletta, C., Gerber, S., Pioletti, D. P., Applegate, L. A., et al. (2008a). Human muscular fetal cells: a potential cell source for muscular therapies. Pediatr. Surg. Int. 24, 37-47. doi: 10.1007/ s00383-007-2040-5
Hirt-Burri, N., Ramelet, A. A., Raffoul, W., de Buys Roessingh, A. S., Scaletta, C., Pioletti, D. P., et al. (2011). Biologicals and fetal cell therapy for wound and scar management. ISRN Dermatol. 2011:549870. doi: 10.5402/2011/549870

Hirt-Burri, N., Scaletta, C., Gerber, S., Pioletti, D. P., and Applegate, L. A. (2008b). Wound-healing gene family expression differences between fetal and foreskin cells used for bioengineered skin substitutes. Artif. Organs. 32, 509-518. doi: 10.1111/j.1525-1594.2008.00578.x

Hodgetts, S. I., Beilharz, M. W., Scalzo, A. A., and Grounds, M. D. (2000). Why do cultured transplanted myoblasts die in vivo? DNA quantification shows enhanced survival of donor male myoblasts in host mice depleted of CD4+ and CD8+ cells or Nk1.1+ cells. Cell Transpl. 9, 489-502. doi: 10.1177/ 096368970000900406

Hodgetts, S. I., Spencer, M. J., and Grounds, M. D. (2003). A role for natural killer cells in the rapid death of cultured donor myoblasts after transplantation. Transplantation 75, 863-871. doi: 10.1097/01.TP.0000053754.33317.4B

Hohlfeld, J., de Buys Roessingh, A. S., Hirt-Burri, N., Chaubert, P., Gerber, S., Scaletta, C., et al. (2005). Tissue engineered fetal skin constructs for paediatric burns. Lancet 366, 840-842. doi: 10.1016/S0140-6736(05)67107-3

Hollister, S. J. (2005). Porous scaffold design for tissue engineering. Nat. Mater. 4, 518-524. doi: 10.1038/nmat1421

Horas, U., Pelinkovic, D., Herr, G., Aigner, T., and Schnettler, R. (2003). Autologous chondrocyte implantation and osteochondral cylinder transplantation in cartilage repair of the knee joint. A prospective, comparative trial. J. Bone Joint Surg. Am. 85, 185-192. doi: 10.2106/00004623-20030200000001

Horwitz, E. M., Prockop, D. J., Fitzpatrick, L. A., Koo, W. W., Gordon, P. L., Neel, M., et al. (1999). Transplantability and therapeutic effects of bone marrowderived mesenchymal cells in children with osteogenesis imperfecta. Nat. Med. 5, 309-313. doi: 10.1038/6529

Huang, A. H., Farrell, M. J., Kim, M., and Mauck, R. L. (2010). Long-term dynamic loading improves the mechanical properties of chondrogenic mesenchymal stem cell-laden hydrogel. Eur. Cell Mater. 19, 72-85. doi: 10.22203/ecm. v019a08

Huang, C. Y., Reuben, P. M., and Cheung, H. S. (2005). Temporal expression patterns and corresponding protein inductions of early responsive genes in rabbit bone marrow-derived mesenchymal stem cells under cyclic compressive loading. Stem Cells 23, 1113-1121. doi: 10.1634/stemcells.2004-0202

Huard, J., Li, Y., and Fu, F. H. (2002). Muscle injuries and repair: current trends in research. J. Bone Joint Surg. Am. 84, 822-832. doi: 10.2106/00004623200205000-00022

Huard, J., Verreault, S., Roy, R., Tremblay, M., and Tremblay, J. P. (1994). High efficiency of muscle regeneration after human myoblast clone transplantation in SCID mice. J. Clin. Invest. 93, 586-599. doi: 10.1172/JCI117011

Huiskes, R., Ruimerman, R., van Lenthe, G. H., and Janssen, J. D. (2000). Effects of mechanical forces on maintenance and adaptation of form in trabecular bone. Nature 405, 704-706. doi: 10.1038/35015116

Hulmes, D. J. (2002). Building collagen molecules, fibrils, and suprafibrillar structures. J. Struct. Biol. 137, 2-10. doi: 10.1006/jsbi.2002.4450

Hunsberger, J., Harrysson, O., Shirwaiker, R., Starly, B., Wysk, R., Cohen, P., et al. (2015). Manufacturing road map for tissue engineering and regenerative medicine technologies. Stem Cells Transl. Med. 4, 130-135. doi: 10.5966/sctm. 2014-0254

Hunt, C. J. (2019). Technical considerations in the freezing, low-temperature storage and thawing of stem cells for cellular therapies. Transfus. Med. Hemother. 46, 134-150. doi: 10.1159/000497289

Hunter, C. J., Mouw, J. K., and Levenston, M. E. (2004). Dynamic compression of chondrocyte-seeded fibrin gels: Effects on matrix accumulation and mechanical stiffness. Osteoarthritis Cartilage 12, 117-130. doi: 10.1016/j.joca.2003.08.009

Hyun, J. S., Tran, M. C., Wong, V. W., Chung, M. T., Lo, D. D., Montoro, D. T., et al. (2013). Enhancing stem cell survival in vivo for tissue repair. Biotechnol. Adv. 31, 736-743. doi: 10.1016/j.biotechadv.2012.11.003

Jacobs, J. P., Jones, C. M., and Baille, J. P. (1970). Characteristics of a human diploid cell designated MRC-5. Nature 227, 168-170. doi: 10.1038/227168a0

Jafari, P., Michetti, M., Yerneni, Y. K., Raffoul, W., and Applegate, L. A. (2017). "Tissue engineering, cell therapy and regenerative medicine: Concepts and applications in plastic surgery," in Textbook of Plastic, Reconstructive, and Aesthetic Surgery, ed. K. Agrawal, and B. Surajit (Uttar Pradesh: Thieme Medical and Scientific Publishers Private Limited ), 345-361. 
Jakubietz, M. G., Jakubietz, D. F., Gruenert, J. G., Zahn, R., Meffert, R. H., and Jakubietz, R. G. (2011). Adequacy of palmaris longus and plantaris tendons for tendon grafting. J. Hand Surg. Am. 36, 695-698. doi: 10.1016/j.jhsa.2011.01.007

James, R., Kesturu, G., Balian, G., and Chhabra, A. B. (2008). Tendon: biology, biomechanics, repair, growth factors, and evolving treatment options. J. Hand Surg. Am. 33, 102-112. doi: 10.1016/j.jhsa.2007.09.007

Jankowski, R. J., Haluszczak, C., Trucco, M., and Huard, J. (2001). Flow cytometric characterization of myogenic cell populations obtained via the preplate technique: Potential for rapid isolation of muscle-derived stem cells. Hum. Gene Ther. 12, 619-628. doi: 10.1089/104303401300057306

Jayaraj, J. S., Janapala, R. N., Qaseem, A., Usman, N., Fathima, N., Kashif, T., et al. (2019). Efficacy and safety of stem cell therapy in advanced heart failure patients: A systematic review with a meta-analysis of recent trials between 2017 and 2019. Cureus 11:e5585. doi: 10.7759/cureus.5585

Johnson, P. C., Bertram, T. A., Tawil, B., and Hellman, K. B. (2011). Hurdles in tissue engineering/regenerative medicine product commercialization: A survey of North American academia and industry. Tissue Eng. Part A. 17, 5-15. doi: 10.1089/ten.TEA.2010.0411

Jost, T. S. (2002). Rights of embryo and foetus in private law. Am. J. Comp. Law 50, 633-646. doi: 10.2307/841064

Kadner, A., Hoerstrup, S. P., Tracy, J., Breymann, C., Maurus, C. F., Melnitchouk, S., et al. (2002). Human umbilical cord cells: A new cell source for cardiovascular tissue engineering. Ann. Thorac. Surg. 74, S1422-S1428. doi: 10.1016/s0003-4975(02)03910-3

Kannus, P. (2000). Structure of the tendon connective tissue. Scand J. Med. Sci. Sports 10, 312-320. doi: 10.1034/j.1600-0838.2000.010006312.x

Kannus, P., and Józsa, L. (1991). Histopathological changes preceding spontaneous rupture of a tendon. A controlled study of 891 patients. J. Bone Joint Surg. Am. 73, 1507-1525. doi: 10.2106/00004623-199173100-00009

Karsenty, G. (2000). Role of Cbfa1 in osteoblast differentiation and function. Semin. Cell Dev. Biol. 11, 343-346. doi: 10.1006/scdb.2000.0188

Katopodi, T., Tew, S. R., Clegg, P. D., and Hardingham, T. E. (2009). The influence of donor and hypoxic conditions on the assembly of cartilage matrix by osteoarthritic human articular chondrocytes on Hyalograft ${ }^{\circledR}$ matrices. Biomaterials 30, 535-540. doi: 10.1016/j.biomaterials.2008.09.064

Kaviani, A., Guleserian, K., Perry, T. E., Jennings, R. W., Ziegler, M. M., and Fauza, D. O. (2003). Fetal tissue engineering from amniotic fluid. J. Am. Coll Surg. 196, 592-597. doi: 10.1016/s1072-7515(02)01834-3

Kaviani, A., Perry, T. E., Barnes, C. M., Oh, J. T., Ziegler, M. M., Fishman, S. J., et al. (2002). The placenta as a cell source in fetal tissue engineering. J. Pediatr. Surg. 37, 995-999. doi: 10.1053/jpsu.2002.33828

Kemppainen, J. M., and Hollister, S. J. (2010). Differential effects of designed scaffold permeability on chondrogenesis by chondrocytes and bone marrow stromal cells. Biomaterials 31, 279-287. doi: 10.1016/j.biomaterials.2009.09.041

Kent, J., and Pfeffer, N. (2006). Regulation the collection and use of fetal stem cells. Brit. Med. J. 332, 866-867. doi: 10.1136/bmj.332.7546.866

Khan, A. A., Shaik, M. V., Parveen, N., Rajendraprasad, A., Aleem, M. A., Habeeb, M. A., et al. (2010). Human fetal liver-derived stem cell transplantation as supportive modality in the management of end-stage decompensated liver cirrhosis. Cell Transpl. 19, 409-418. doi: 10.3727/096368910X498241

Kim, H. R., Kim, J., Park, S. R., Min, B. H., and Choi, B. H. (2018). Characterization of human fetal cartilage progenitor cells during long-term expansion in a xenofree medium. Tissue Eng. Regen. Med. 15, 649-659. doi: 10.1007/s13770-0180132-z

Klenke, F. M., Liu, Y., Yuan, H., Hunziker, E. B., Siebenrock, K. A., and Hofstetter, W. (2008). Impact of pore size on the vascularization and osseointegration of ceramic bone substitutes in vivo. J. Biomed. Mater. Res. A. 85, 777-786. doi: 10.1002/jbm.a.31559

Koch, T. G., Berg, L. C., and Betts, D. H. (2009). Current and future regenerative medicine - Principles, concepts, and therapeutic use of stem cell therapy and tissue engineering in equine medicine. Can. Vet. J. 50, 155-165.

Krähenbühl, S. M., Grognuz, A., Michetti, M., Raffoul, W., and Applegate, L. A. (2015). Enhancement of human adipose-derived stem cell expansion and stability for clinical use. Int. J. Stem Cell Res. Ther. 2:007. doi: 10.23937/2469570X/1410007

Krattinger, N., Applegate, L. A., Biver, E., Pioletti, D. P., and Caverzasio, J. (2011). Regulation of proliferation and differentiation of human fetal bone cells. Eur. Cell Mater. 21, 46-58. doi: 10.22203/ecm.v021a04
Krauss Juillerat, F., Borcard, F., Staedler, D., Scaletta, C., Applegate, L. A., Comas, H., et al. (2012). Functionalization of microstructured open-porous bioceramic scaffolds with human fetal bone cells. Bioconj. Chem. 23, 2278-2290. doi: 10. 1021/bc300407x

Kumar, R. J., Kimble, R. M., Boots, R. J., and Pegg, S. P. (2004). Treatment of partialthickness burns: A prospective, randomized trial using TransCyte ${ }^{\circledR}$. ANZ J. Surg. 74, 622-626. doi: 10.1111/j.1445-1433.2004.03106.x

Lapp, A., Furrer, P., Ramelet, A. A., Aubort, C., Aubort, P., Laurent, P., et al. (2013). Cellular derivatives and efficacy in wound and scar management. JCDSA 3, 36-45. doi: 10.4236/jcdsa.2013.31A007

Larijani, B., Ghahari, A., Warnock, G. L., Aghayan, H. R., Goodarzi, P., Falahzadeh, K., et al. (2015). Human fetal skin fibroblasts: Extremely potent and allogenic candidates for treatment of diabetic wounds. Med. Hypothes. 84, 577-579. doi: 10.1016/j.mehy.2015.03.004

Laurent, A., Abdel-Sayed, P., Chemali, M., Hirt-Burri, N., Raffoul, W., Applegate, L. A., et al. (2020a). Bonnes Pratiques de Fabrication et thérapies cellulaires au chevet des grands brûlés romands. Lincoln: UNL.

Laurent, A., Darwiche, S. E., Hirt-Burri, N., Scaletta, C., Michetti, M., Laurent, P., et al. (2020b). Banking progenitor cells for hippiatric regenerative medicine: Optimized establishment of safe and consistent cell sources for standardized veterinary therapeutic protocols. AJBSR 8, 252-271. doi: 10.34297/AJBSR.2020. 08.001284

Laurent, A., Hirt-Burri, N., Amiot, C., Scaletta, C., Applegate, L. A., and de Buys Roessingh, A. S. (2020c). Primary progenitor muscle cells for regenerative medicine: Standardization of therapeutic protocols and optimized in vivo murine model for volumetric muscle loss. AJBSR 8, 143-153. doi: 10.34297/ AJBSR.2020.08.001257

Laurent, A., Hirt-Burri, N., Scaletta, C., Applegate, L. A., and de Buys Roessingh, A. S. (2020d). Immune privilege of primary fetal progenitor cells: Optimized safety profile of consistent cell sources for cutaneous and musculoskeletal regenerative medicine. AJBSR 8, 516-520. doi: 10.34297/AJBSR.2020.08.00 1330

Laurent, A., Lin, P., Scaletta, C., Hirt-Burri, N., Michetti, M., de Buys Roessingh, A. S., et al. (2020e). Bringing safe and standardized cell therapies to industrialized processing for burns and wounds. Front. Bioeng. Biotechnol. 8:581. doi: $10.3389 /$ fbioe.2020.00581

Laurent, A., Scaletta, C., Hirt-Burri, N., Raffoul, W., de Buys Roessingh, A. S., and Applegate, L. A. (2020f). "Swiss Fetal Transplantation Program and nonenzymatically isolated primary progenitor cell types for regenerative medicine," in Stem Cells and Good Manufacturing Practices: Methods and Protocols, ed. T. Kursad (New York: Springer). doi: 10.1007/7651_2020_294

Laurent, A., Scaletta, C., Michetti, M., Hirt-Burri, N., de Buys Roessingh, A. S., and Raffoul, W. (2020g). "GMP tiered cell banking of non-enzymatically isolated dermal progenitor fibroblasts for allogenic regenerative medicine," in Stem Cells and Good Manufacturing Practices: Methods and Protocols, ed. T. Kursad (New York: Springer Protocols). doi: 10.1007/7651_2020_295

Laurent, A., Scaletta, C., Michetti, M., Hirt-Burri, N., Flahaut, M., and Raffoul, W. (2020h). "Progenitor Biological Bandages: An authentic Swiss tool for safe therapeutic management of burns, ulcers and donor site grafts," in Stem Cells and Good Manufacturing Practices: Methods and Protocols, ed. T. Kursad (New York: Springer Protocols). doi: 10.1007/7651_2020_296

Laurent, A., Simon, J. P., Hirt-Burri, N., Raffoul, W., Applegate, L. A., and de Buys Roessingh, A. S. (2020i). GMP-grade allogeneic musculoskeletal primary progenitor cell types: Standardized candidates for general or Pharmacopeial monograph elaboration. J. Transl. Sci. 7, 1-3. doi: 10.15761/JTS.1000406

Lawler, S. D. (1981). Conception and development of the fetal tissue bank. J. Clin. Pathol. 34, 240-248. doi: 10.1136/jcp.34.3.240

Le Blanc, K., Tammik, C., Rosendahl, K., Zetterberg, E., and Ringdén, O. (2003). HLA expression and immunologic properties of differentiated and undifferentiated mesenchymal stem cells. Exp. Hematol. 31, 890-896. doi: 10. 1016/s0301-472x(03)00110-3

Lee, J., Rabbani, C. C., Gao, H., Steinhart, M. R., Woodruff, B. M., Pflum, Z. E., et al. (2020). Hair-bearing human skin generated entirely from pluripotent stem cells. Nature 582, 399-404. doi: 10.1038/s41586-020-2352-3

Levinson, C., Lee, M., Applegate, L. A., and Zenobi-Wong, M. (2019). An injectable heparin-conjugated hyaluronan scaffold for local delivery of transforming growth factor $\beta 1$ promotes successful chondrogenesis. Acta Biomater 99, 168180. doi: 10.1016/j.actbio.2019.09.017 
Lewis, C. M., and Tarrant, G. M. (1972). Error theory and ageing in human diploid fibroblasts. Nature 239, 316-318. doi: 10.1038/239316a0

Li, F., Levinson, C., Truong, V. X., Laurent-Applegate, L. A., Maniura-Weber, K., and Thissen, H. (2020). Microencapsulation improves chondrogenesis in vitro and cartilaginous matrix stability in vivo compared to bulk encapsulation. Biomater Sci. 8, 1711-1725. doi: 10.1039/c9bm01524h

Li, Z., and Maitz, P. (2018). Cell therapy for severe burn wound healing. Burns Trauma. 6:13. doi: 10.1186/s41038-018-0117-0

Li, Z., Yao, S. J., Alini, M., and Stoddart, M. J. (2010). Chondrogenesis of human bone marrow mesenchymal stem cells in fibrin-polyurethane composites is modulated by frequency and amplitude of dynamic compression and shear stress. Tissue Eng. Part A. 16, 575-584. doi: 10.1089/ten.TEA.2009. 0262

Lima-Junior, E. M., de Moraes Filho, M. O., Costa, B. A., Fechine, F. V., de Moraes, M., Silva-Junior, F. R., et al. (2019). Innovative treatment using tilapia skin as a xenograft for partial thickness burns after a gunpowder explosion. J. Surg. Case Rep. 2019:rjz181. doi: 10.1093/jscr/rjz181

Limat, A., and Hunziker, T. (2002). Use of epidermal equivalents generated from follicular outer root sheath cells in vitro and for autologous grafting of chronic wounds. Cells Tissues Organs. 172, 79-85. doi: 10.1159/000065615

Limat, A., Mauri, D., and Hunziker, T. (1996). Successful treatment of chronic leg ulcers with epidermal equivalents generated from cultured autologous outer root sheath cells. J. Invest. Dermatol. 107, 128-135. doi: 10.1111/1523-1747. ep12298415

Litzke, L. E., Wagner, E., Baumgaertner, W., Hetzel, U., Josimoviæ-Alaseviæ, O., and Libera, J. (2004). Repair of extensive articular cartilage defects in horses by autologous chondrocyte transplantation. Ann. Biomed. Eng. 32, 57-69. doi: 10.1023/b:abme.0000007791.81433.1a

Loebel, C., and Burdick, J. A. (2018). Engineering stem and stromal cell therapies for musculoskeletal tissue repair. Cell Stem Cell 22, 325-339. doi: 10.1016/j. stem.2018.01.014

Longaker, M. T., Moelleken, B. R., Cheng, J. C., Jennings, R. W., Adzick, N. S., Mintorovich, J., et al. (1992). Fetal fracture healing in a lamb model. Plast. Reconstr. Surg. 90, 161-171. doi: 10.1097/00006534-199208000-00001

Lorant, J., Poinas, A., Nerriere, O., Vrignaud, F., Frenard, C., Winer, N., et al. (2019). Foetal skin cells in wound healing: A promising tool for clinical application. Eur. J. Dermatol. 29, 585-595. doi: 10.1684/ejd.2019.3675

Lovati, A. B., Bottagisio, M., and Moretti, M. (2016). Decellularized and engineered tendons as biological substitutes: A critical review. Stem Cells Int. 2016:7276150. doi: 10.1155/2016/7276150

Lu, Y., Dhanaraj, S., Wang, Z., Bradley, D. M., Bowman, S. M., Cole, B. J., et al. (2006). Minced cartilage without cell culture serves as an effective intraoperative cell source for cartilage repair. J. Orthop. Res. 24, 1261-1270. doi: 10.1002/jor. 20135

Lukish, J. R., Eichelberger, M. R., and Newman, K. D. (2001). The use of a bioactive skin substitute decreases length of stay for pediatric burn patients. J. Pediatr. Surg. 36, 1118-1121. doi: 10.1053/jpsu.2001.25678

Ma, B., He, L. F., Zhang, Y. L., Chen, M., Wang, L. L., Yang, H. W., et al. (2015). Characteristics and viral propagation properties of a new human diploid cell line. Hum. Vaccin. Immunother. 11, 998-1009. doi: 10.1080/21645515.2015. 1009811

Madeira, C., Santhagunam, A., Salgueiro, J. B., and Cabral, J. M. (2015). Advanced cell therapies for articular cartilage regeneration. Trends Biotechnol. 33, 35-42. doi: 10.1016/j.tibtech.2014.11.003

Maffulli, N., Wong, J., and Almekinders, L. C. (2003). Types and epidemiology of tendinopathy. Clin. Sports Med. 22, 675-692. doi: 10.1016/s0278-5919(03) 00004-8

Maher, D. P., Panicola, M. R., and Harte, C. (2002). Vaccines, abortions and moral coherence. Natl. Cathol. Bioeth. Q. 2, 51-67. doi: 10.5840/ncbq20022178

Makris, E. A., Gomoll, A. H., Malizos, K. N., Hu, J. C., and Athanasiou, K. A. (2015). Repair and tissue engineering techniques for articular cartilage. Nat. Rev. Rheumatol. 11, 21-34. doi: 10.1038/nrrheum.2014.157

Malhotra, C., and Jain, A. K. (2014). Human amniotic membrane transplantation: Different modalities of its use in ophthalmology. World J. Transpl. 4, 111-121. doi: $10.5500 /$ wjt.v4.i2.111

Manier, J. (2002). Bush administration quietly approves fetal stem cell work: Funding allowed despite federal limits on embryo use. J. Invest. Med. 50, 341-342. doi: $10.2310 / 6650.2002 .32739$
Mardones, R., Jofré, C. M., and Minguell, J. J. (2015). Cell therapy and tissue engineering approaches for cartilage repair and/or regeneration. Int. J. Stem Cells 8, 48-53. doi: 10.15283/ijsc.2015.8.1.48

Markeson, D., Pleat, J. M., Sharpe, J. R., Harris, A. L., Seifalian, A. M., and Watt, S. M. (2015). Scarring, stem cells, scaffolds and skin repair. J. Tissue Eng. Regen. Med. 9, 649-668. doi: 10.1002/term.1841

Marks, P., and Gottlieb, S. (2018). Balancing safety and innovation for cellbased regenerative medicine. N. Engl. J. Med. 378, 954-959. doi: 10.1056/ NEJMsr1715626

Mauck, R. L., Byers, B. A., Yuan, X., and Tuan, R. S. (2007). Regulation of cartilaginous ECM gene transcription by chondrocytes and MSCs in 3D culture in response to dynamic loading. Biomech. Model Mechanobiol. 6, 113-125. doi: 10.1007/s10237-006-0042-1

Mauney, J. R., Volloch, V., and Kaplan, D. L. (2005). Role of adult mesenchymal stem cells in bone tissue engineering applications: Current status and future prospects. Tissue Eng. 11, 787-802. doi: 10.1089/ten.2005.11.787

Maurel, A., Azarnoush, K., Sabbah, L., Vignier, N., Le Lorc'h, M., Mandet, C., et al. (2005). Can cold or heat shock improve skeletal myoblast engraftment in infarcted myocardium? Transplantation 80, 660-665. doi: 10.1097/01.tp. 0000172178.35488 .31

Meisel, H. J., Ganey, T., Hutton, W. C., Libera, J., Minkus, Y., and Alasevic, O. (2006). Clinical experience in cell-based therapeutics: Intervention and outcome. Eur. Spine J. 15(Suppl. 3), S397-S405. doi: 10.1007/s00586-0060169-x

Meisel, H. J., Siodla, V., Ganey, T., Minkus, Y., Hutton, W. C., and Alasevic, O. J. (2007). Clinical experience in cell-based therapeutics: Disc chondrocyte transplantation: A treatment for degenerated or damaged intervertebral disc. Biomol. Eng. 24, 5-21. doi: 10.1016/j.bioeng.2006.07.002

Melchels, F. P., Barradas, A. M., van Blitterswijk, C. A., de Boer, J., Feijen, J., and Grijpma, D. W. (2010). Effects of the architecture of tissue engineering scaffolds on cell seeding and culturing. Acta Biomater. 6, 4208-4217. doi: 10. 1016/j.actbio.2010.06.012

Mellor, L. F., Baker, T. L., Brown, R. J., Catlin, L. W., and Oxford, J. T. (2014). Optimal 3D culture of primary articular chondrocytes for use in the rotating wall vessel bioreactor. Aviat. Space Environ. Med. 85, 798-804. doi: 10.3357/ ASEM.3905.2014

Melrose, J., Smith, S., and Ghosh, P. (2000). Differential expression of proteoglycan epitopes by ovine intervertebral disc cells. J. Anat 197(Pt2), 189-198. doi: 10. 1046/j.1469-7580.2000.19720189.x

Menasché, P. (2005). Skeletal myoblast for cell therapy. Coron. Artery Dis. 16, 105-110. doi: 10.1097/00019501-200503000-00005

Mendell, J. R., Kissel, J. T., Amato, A. A., King, W., Signore, L., Prior, T. W., et al. (1995). Myoblast transfer in the treatment of Duchenne's muscular dystrophy. N. Engl. J. Med. 333, 832-838. doi: 10.1056/NEJM199509283331303

Mendes, R. M., Silva, G. A., Lima, M. F., Calliari, M. V., Almeida, A. P., Alves, J. B., et al. (2008). Sodium hyaluronate accelerates the healing process in tooth sockets of rats. Arch. Oral. Biol. 53, 1155-1162. doi: 10.1016/j.archoralbio.2008. 07.001

Mendes, S. C., Tibbe, J. M., Veenhof, M., Both, S., Oner, F. C., and van Blitterswijk, C. A. (2004). Relation between in vitro and in vivo osteogenic potential of cultured human bone marrow stromal cells. J. Mater. Sci. Mater. Med. 15, 1123-1128. doi: 10.1023/B:JMSM.0000046394.53153.21

Metcalfe, A. D., and Ferguson, M. W. (2007). Tissue engineering of replacement skin: The crossroads of biomaterials, wound healing, embryonic development, stem cells and regeneration. J. R. Soc. Interf. 4, 413-437. doi: 10.1098/rsif.2006. 0179

Metcalfe, A. D., and Ferguson, M. W. (2008). Skin stem and progenitor cells: Using regeneration as a tissue-engineering strategy. Cell Mol. Life Sci. 65, 24-32. doi: 10.1007/s00018-007-7427-x

Mhanna, R., Kashyap, A., Palazzolo, G., Vallmajo-Martin, Q., Becher, J., Möller, S., et al. (2014). Chondrocyte culture in three-dimensional alginate sulfate hydrogels promotes proliferation while maintaining expression of chondrogenic markers. Tissue Eng. Part A. 20, 1454-1464. doi: 10.1089/ten. TEA.2013.0544

Miller, R. G., Sharma, K. R., Pavlath, G. K., Gussoni, E., Mynhier, M., Lanctot, A. M., et al. (1997). Myoblast implantation in Duchenne muscular dystrophy: The San Francisco study. Musc. Nerve 20, 469-478. doi: 10.1002/(sici)10974598(199704)20:4<469::aid-mus10<3.0.co;2-u 
Mirmalek-Sani, S. H., Tare, R. S., Morgan, S. M., Roach, H. I., Wilson, D. I., Hanley, N. A., et al. (2006). Characterization and multipotentiality of human fetal femur-derived cells: Implications for skeletal tissue regeneration. Stem Cells 24, 1042-1053. doi: 10.1634/stemcells.2005-0368

Mok, S. S., Masuda, K., Häuselmann, H. J., Aydelotte, M. B., and Thonar, E. J. (1994). Aggrecan synthesized by mature bovine chondrocytes suspended in alginate. Identification of two distinct metabolic matrix pools. J. Biol Chem. 269, 33021-33027.

Momeni, M., Fallah, N., Bajouri, A., Bagheri, T., Orouji, Z., Pahlevanpour, P., et al. (2019). A randomized, double-blind, phase I clinical trial of fetal cell-based skin substitutes on healing of donor sites in burn patients. Burns 45, 914-922. doi: 10.1016/j.burns.2018.10.016

Montanucci, P., Pennoni, I., Pescara, T., Basta, G., and Calafiore, R. (2013). Treatment of diabetes mellitus with microencapsulated fetal human liver (FH-B-TPN) engineered cells. Biomaterials 34, 4002-4012. doi: 10.1016/j. biomaterials.2013.02.026

Montarras, D., Morgan, J., Collins, C., Relaix, F., Zaffran, S., Cumano, A., et al. (2005). Direct isolation of satellite cells for skeletal muscle regeneration. Science 309, 2064-2067. doi: 10.1126/science.1114758

Monti, M., Perotti, C., Del Fante, C., Cervio, M., and Redi, C. A. (2012). Stem cells: Sources and therapies. Biol. Res. 45, 207-214. doi: 10.4067/S071697602012000300002

Montjovent, M. O., Bocelli-Tyndall, C., Scaletta, C., Scherberich, A., Mark, S., Martin, I., et al. (2009). In vitro characterization of immune-related properties of human fetal bone cells for potential tissue engineering applications. Tissue Eng. Part A. 15, 1523-1532. doi: 10.1089/ten.tea.2008.0222

Montjovent, M. O., Burri, N., Mark, S., Federici, E., Scaletta, C., Zambelli, P. Y., et al. (2004). Fetal bone cells for tissue engineering. Bone 35, 1323-1333. doi: 10.1016/j.bone.2004.07.001

Montjovent, M. O., Mark, S., Mathieu, L., Scaletta, C., Scherberich, A., Delabarde, C., et al. (2008). Human fetal bone cells associated with ceramic reinforced PLA scaffolds for tissue engineering. Bone 42, 554-564. doi: 10.1016/j.bone.2007. 10.018

Montjovent, M. O., Mathieu, L., Schmoekel, H., Mark, S., Bourban, P. E., and Zambelli, P. Y. (2007). Repair of critical size defects in the rat cranium using ceramic-reinforced PLA scaffolds obtained by supercritical gas foaming. J. Biomed. Mater. Res. A. 83, 41-51. doi: 10.1002/jbm.a.31208

Moore, A. L., Marshall, C. D., Barnes, L. A., Murphy, M. P., Ransom, R. C., and Longaker, M. T. (2018). Scarless wound healing: Transitioning from fetal research to regenerative healing. Wiley Interdisc. Rev. Dev. Biol. 7:10.1002/wdev.309. doi: 10.1002/wdev.309

Moretti, M., Wendt, D., Dickinson, S. C., Sims, T. J., Hollander, A. P., Kelly, D. J., et al. (2005). Effects of in vitro preculture on in vivo development of human engineered cartilage in an ectopic model. Tissue Eng. 11, 1421-1428. doi: 10.1089/ten.2005.11.1421

Mount, N. M., Ward, S. J., Kefalas, P., and Hyllner, J. (2015). Cell-based therapy technology classifications and translational challenges. Philos. Trans. R. Soc. Lond B. Biol. Sci. 370:20150017. doi: 10.1098/rstb.2015.0017

Muraca, M., Piccoli, M., Franzin, C., Tolomeo, A. M., Jurga, M., Pozzobon, M., et al. (2017). Diverging concepts and novel perspectives in regenerative medicine. Int. J. Mol. Sci. 18:1021. doi: 10.3390/ijms18051021

Murchison, N. D., Price, B. A., Conner, D. A., Keene, D. R., Olson, E. N., Tabin, C. J., et al. (2007). Regulation of tendon differentiation by scleraxis distinguishes force-transmitting tendons from muscle-anchoring tendons. Development 134, 2697-2708. doi: 10.1242/dev.001933

Murugan, V. (2009). Embryonic stem cell research: A decade of debate from Bush to Obama. Yale J. Biol. Med. 82, 101-103.

Nakatomi, H., Kuriu, T., Okabe, S., Yamamoto, S., Hatano, O., Kawahara, N., et al. (2002). Regeneration of hippocampal pyramidal neurons after ischemic brain injury by recruitment of endogenous neural progenitors. Cell 110, 429-441. doi: 10.1016/s0092-8674(02)00862-0

Namba, R. S., Meuli, M., Sullivan, K. M., Le, A. X., and Adzick, N. S. (1998). Spontaneous repair of superficial defects in articular cartilage in a fetal lamb model. J. Bone Joint Surg. Am. 80, 4-10. doi: 10.2106/00004623-19980100000003

Nasrollahzadeh, N., Applegate, L. A., and Pioletti, D. P. (2017). Development of an effective cell seeding technique: Simulation, implementation, and analysis of contributing factors. Tissue Eng. Part C Methods. 23, 485-496. doi: 10.1089/ten. TEC.2017.0108

Ng, K. W., Khor, H. L., and Hutmacher, D. W. (2004). In vitro characterization of natural and synthetic dermal matrices cultured with human dermal fibroblasts. Biomaterials 25, 2807-2818. doi: 10.1016/j.biomaterials.2003.09.058

O’Brien, M. (1997). Structure and metabolism of tendons. Scand J. Med. Sci. Sports 7, 55-61. doi: 10.1111/j.1600-0838.1997.tb00119.x

Ober, C. (1998). HLA and pregnancy: The paradox of the fetal allograft. Am. J. Hum. Genet. 62, 1-5. doi: 10.1086/301692

Ohgushi, H., and Caplan, A. I. (1999). Stem cell technology and bioceramics: From cell to gene engineering. J. Biomed. Mater. Res. 48, 913-927. doi: 10.1002/(sici) 1097-4636199948:6<913::aid-jbm22<3.0.co;2-0

Olshansky, S. J., and Hayflick, L. (2017). The role of the WI-38 cell strain in saving lives and reducing morbidity. AIMS Publ. Health 4, 127-138. doi: 10.3934/ publichealth.2017.2.127

Oreffo, R. O., Cooper, C., Mason, C., and Clements, M. (2005). Mesenchymal stem cells: Lineage, plasticity, and skeletal therapeutic potential. Stem Cell Rev. 1, 169-78. doi: 10.1385/SCR:1:2:169

Ostrer, H., Wilson, D. I., and Hanley, N. A. (2006). Human embryo and early fetus research. Clin. Genet. 70, 98-107. doi: 10.1111/j.1399-0004.2006.00640.x

Palache, A. M., Brands, R., and van Scharrenburg, G. J. (1997). Immunogenicity and reactogenicity of influenza subunit vaccines produced in MDCK cells or fertilized chicken eggs. J. Infect. Dis. 176(Suppl. 1), S20-S23. doi: 10.1086/ 514169

Panikkar, B., Smith, N., and Brown, P. (2012). Reflexive research ethics in fetal tissue xenotransplantation research. Account Res. 19, 344-369. doi: 10.1080/ 08989621.2012 .728910

Parikh, S. N. (2002). Bone graft substitutes: past, present, future. J. Postgrad. Med. 48, 142-148.

Partridge, T. A., Grounds, M., and Sloper, J. C. (1978). Evidence of fusion between host and donor myoblasts in skeletal muscle grafts. Nature 273, 306-308. doi: $10.1038 / 273306 \mathrm{a} 0$

Passipieri, J. A., and Christ, G. J. (2016). The potential of combination therapeutics for more complete repair of volumetric muscle loss injuries: The role of exogenous growth factors and/or progenitor cells in implantable skeletal muscle tissue engineering technologies. Cells Tissues Organs. 202, 202-213. doi: 10. $1159 / 000447323$

Patino, M. G., Neiders, M. E., Andreana, S., Noble, B., and Cohen, R. E. (2002). Collagen as an implantable material in medicine and dentistry. J. Oral. Implantol. 28, 220-225. doi: 10.1563/1548-13362002028<0220:CAAIMI<2.3. $\mathrm{CO} ; 2$

Patrulea, V., Applegate, L. A., Ostafe, V., Jordan, O., and Borchard, G. (2015). Optimized synthesis of O-carboxymethyl-N,N,N-trimethyl chitosan. Carbohydr. Polym. 122, 46-52. doi: 10.1016/j.carbpol.2014.12.014

Patrulea, V., Laurent-Applegate, L. A., Ostafe, V., Borchard, G., and Jordan, O. (2019). Polyelectrolyte nanocomplexes based on chitosan derivatives for wound healing application. Eur. J. Pharm. Biopharm. 140, 100-108. doi: 10.1016/j.ejpb. 2019.05.009

Pavlath, G. K., Rando, T. A., and Blau, H. M. (1994). Transient immunosuppressive treatment leads to long-term retention of allogeneic myoblasts in hybrid myofibers. J. Cell Biol. 127, 1923-1932. doi: 10.1083/jcb.127.6. 1923

Pearce, K. F., Hildebrandt, M., Greinix, H., Scheding, S., and Koehl, U. (2014). Regulation of advanced therapy medicinal products in Europe and the role of academia. Cytotherapy 16, 289-297. doi: 10.1016/j.jcyt.2013.08.003

Pelttari, K., Pippenger, B., Mumme, M., Feliciano, S., Scotti, C., Mainil-Varlet, P., et al. (2014). Adult human neural crest-derived cells for articular cartilage repair. Sci. Transl. Med. 6:251ra119. doi: 10.1126/scitranslmed.3009688

Petes, T. D., Farber, R. A., Tarrant, G. M., and Holliday, R. (1974). Altered rate of DNA replication in ageing human fibroblast cultures. Nature 251, 434-436. doi: 10.1038/251434a0

Petite, H., Viateau, V., Bensaïd, W., Meunier, A., de Pollak, C., Bourguignon, M., et al. (2000). Tissue-engineered bone regeneration. Nat. Biotechnol. 18, 959-963. doi: $10.1038 / 79449$

Petrou, I. G., Grognuz, A., Hirt-Burri, N., Raffoul, W., and Applegate, L. A. (2014). Cell therapies for tendons: Old cell choice for modern innovation. Swiss Med. Wkly. 144:w13989. doi: 10.4414/smw.2014.13989 
Pfeffer, N., and Kent, J. (2006). Consent to the use of aborted fetuses in stem cell research and therapies. Clin. Ethics 1, 216-218. doi: 10.1258/ 147775006779151210

Piccinni, M. P. (2010). T cell tolerance towards the fetal allograft. J. Reprod. Immunol. 85, 71-75. doi: 10.1016/j.jri.2010.01.006

Pigeau, G. M., Csaszar, E., and Dulgar-Tulloch, A. (2018). Commercial scale manufacturing of allogeneic cell therapy. Front. Med. 5:233. doi: 10.3389/fmed. 2018.00233

Pioletti, D. P., Montjovent, M. O., Zambelli, P. Y., and Applegate, L. A. (2006). Bone tissue engineering using foetal cell therapy. Swiss Med. Wkly. 136, 557-560.

Pirnay, J. P., Vanderkelen, A., De Vos, D., Draye, J. P., Rose, T., Ceulemans, C., et al. (2013). Business oriented EU human cell and tissue product legislation will adversely impact Member States' health care systems. Cell Tissue Bank 14, 525-560. doi: 10.1007/s10561-013-9397-6

Pirnay, J. P., Verbeken, G., Ceyssens, P. J., Huys, I., and De Vos, D. (2018). The magistral phage. Viruses 10:64. doi: 10.3390/v10020064

Pittenger, M. F., Discher, D. E., Péault, B. M., Phinney, D. G., Hare, J. M., and Caplan, A. I. (2019). Mesenchymal stem cell perspective: Cell biology to clinical progress. NPJ Regen Med. 4:22. doi: 10.1038/s41536-019-0083-6

Pleumeekers, M. M., Nimeskern, L., Koevoet, W. L., Kops, N., Poublon, R. M., Stok, K. S., et al. (2014). The in vitro and in vivo capacity of culture-expanded human cells from several sources encapsulated in alginate to form cartilage. Eur. Cell Mater. 27, 264-280. doi: 10.22203/ecm.v027a19

Poinas, A., Perrot, P., Lorant, J., Nerrière, O., Nguyen, J. M., Saiagh, S., et al. (2019). CICAFAST: comparison of a biological dressing composed of fetal fibroblasts and keratinocytes on a split-thickness skin graft donor site versus a traditional dressing: a randomized controlled trial. Trials 20:612. doi: 10.1186/s13063-0193718-4

Pontifical Academy for Life. (2006). Moral reflections on vaccines prepared from cells derived from aborted human fetuses. Natl .Cathol. Bioeth. Q. 6, 537-541. doi: $10.5840 / n c b q 20066334$

Pridgen, B. C., Woon, C. Y., Kim, M., Thorfinn, J., Lindsey, D., Pham, H., et al. (2011). Flexor tendon tissue engineering: Acellularization of human flexor tendons with preservation of biomechanical properties and biocompatibility. Tissue Eng. Part C Methods. 17, 819-828. doi: 10.1089/ten.tec.2010.0457

Prockop, D. J. (2009). Repair of tissues by adult stem/progenitor cells (MSCs): Controversies, myths, and changing paradigms. Mol. Ther. 17, 939-946. doi: $10.1038 / \mathrm{mt} .2009 .62$

Providence, K. M., Higgins, S. P., Mullen, A., Battista, A., Samarakoon, R., Higgins, C. E., et al. (2008). SERPINE1 (PAI-1) is deposited into keratinocyte migration "trails" and required for optimal monolayer wound repair. Arch. Dermatol. Res. 300, 303-310. doi: 10.1007/s00403-008-0845-2

Qu, Z., Balkir, L., van Deutekom, J. C., Robbins, P. D., Pruchnic, R., and Huard, J. (1998). Development of approaches to improve cell survival in myoblast transfer therapy. J. Cell Biol. 142, 1257-1267. doi: 10.1083/jcb.142.5.1257

Quintin, A., Hirt-Burri, N., Scaletta, C., Schizas, C., Pioletti, D. P., and Applegate, L. A. (2007). Consistency and safety of cell banks for research and clinical use: Preliminary analysis of fetal skin banks. Cell Transpl. 16, 675-684. doi: 10.3727/000000007783465127

Quintin, A., Schizas, C., Scaletta, C., Jaccoud, S., Applegate, L. A., and Pioletti, D. P. (2010). Plasticity of fetal cartilaginous cells. Cell Transpl. 19, 1349-1357. doi: 10.3727/096368910X506854

Quintin, A., Schizas, C., Scaletta, C., Jaccoud, S., Gerber, S., Osterheld, M. C., et al. (2009). Isolation and in vitro chondrogenic potential of human foetal spine cells. J. Cell Mol. Med. 13, 2559-2569. doi: 10.1111/j.1582-4934.2008.00630.x

Rahman, A., Katzive, L., and Henshaw, S. K. (1998). A global review of laws on induced abortion, 1985-1997. Int. Fam. Plann. Persp. 24, 56-64. doi: 10.2307/ 2991926

Ramelet, A. A., Hirt-Burri, N., Raffoul, W., Scaletta, C., Pioletti, D. P., Offord, E., et al. (2009). Chronic wound healing by fetal cell therapy may be explained by differential gene profiling observed in fetal versus old skin cells. Exp. Gerontol. 44, 208-218. doi: 10.1016/j.exger.2008.11.004

Ratcliffe, E., Thomas, R. J., and Williams, D. J. (2011). Current understanding and challenges in bioprocessing of stem cell-based therapies for regenerative medicine. Br. Med. Bull. 100, 137-155. doi: 10.1093/bmb/ldr037

Rayment, E. A., and Williams, D. J. (2010). Concise review: Mind the gap: Challenges in characterizing and quantifying cell- and tissue-based therapies for clinical translation. Stem Cells 28, 996-1004. doi: 10.1002/stem.416
Reier, P. J. (2004). Cellular transplantation strategies for spinal cord injury and translational neurobiology. NeuroRx. 1, 424-451. doi: 10.1602/neurorx.1.4.424

Reinking, M. (2012). Tendinopathy in athletes. Phys. Ther. Sport 13, 3-10. doi: 10.1016/j.ptsp.2011.06.004

Reisinger, K. S., Block, S. L., Izu, A., Groth, N., and Holmes, S. J. (2009). Subunit influenza vaccines produced from cell culture or in embryonated chicken eggs: Comparison of safety, reactogenicity, and immunogenicity. J. Infect. Dis. 200, 849-857. doi: 10.1086/605506

Rieske, P., Krynska, B., and Azizi, S. A. (2005). Human fibroblast-derived cell lines have characteristics of embryonic stem cells and cells of neuroectodermal origin. Differentiation 73, 474-483. doi: 10.1111/j.1432-0436.2005. 00050.x

Roche, S., Ronzière, M. C., Herbage, D., and Freyria, A. M. (2001). Native and DPPA cross-linked collagen sponges seeded with fetal bovine epiphyseal chondrocytes used for cartilage tissue engineering. Biomaterials 22, 9-18. doi: 10.1016/s0142-9612(00)00084-3

Rodrigues, M., Kosaric, N., Bonham, C. A., and Gurtner, G. C. (2019). Wound healing: A cellular perspective. Physiol. Rev. 99, 665-706. doi: 10.1152/physrev. 00067.2017

Roh, J. D., Nelson, G. N., Udelsman, B. V., Brennan, M. P., Lockhart, B., Fong, P. M., et al. (2007). Centrifugal seeding increases seeding efficiency and cellular distribution of bone marrow stromal cells in porous biodegradable scaffolds. Tissue Eng. 13, 2743-2749. doi: 10.1089/ten.2007.0171

Rose, F. R., and Oreffo, R. O. (2002). Bone tissue engineering: Hope vs hype. Biochem. Biophys. Res. Commun. 292, 1-7. doi: 10.1006/bbrc.2002. 6519

Roshan-Ghias, A., Terrier, A., Bourban, P. E., and Pioletti, D. P. (2010). In vivo cyclic loading as a potent stimulatory signal for bone formation inside tissue engineering scaffold. Eur. Cell Mater. 19, 41-49. doi: 10.22203/ecm.v019a05

Rosser, A. E., and Dunnett, S. B. (2003). Neural transplantation in patients with Huntington's disease. CNS Drugs 17, 853-867. doi: 10.2165/00023210200317120-00001

Rouas-Freiss, N., Marchal, R. E., Kirszenbaum, M., Dausset, J., and Carosella, E. D. (1997). The alpha1 domain of HLA-G1 and HLA-G2 inhibits cytotoxicity induced by natural killer cells: Is HLA-G the public ligand for natural killer cell inhibitory receptors? Proc. Natl. Acad. Sci. U S A. 94, 5249-5254. doi: 10.1073/pnas.94.10.5249

Sacchetti, M., Rama, P., Bruscolini, A., and Lambiase, A. (2018). Limbal stem cell transplantation: Clinical results, limits, and perspectives. Stem Cells Int. 2018:8086269. doi: 10.1155/2018/8086269

Sakai, D., Mochida, J., Iwashina, T., Hiyama, A., Omi, H., Imai, M., et al. (2006). Regenerative effects of transplanting mesenchymal stem cells embedded in atelocollagen to the degenerated intervertebral disc. Biomaterials 27, 335-345. doi: 10.1016/j.biomaterials.2005.06.038

Sammels, L. M., Bosio, E., Fragall, C. T., Grounds, M. D., van Rooijen, N., and Beilharz, M. W. (2004). Innate inflammatory cells are not responsible for early death of donor myoblasts after myoblast transfer therapy. Transplantation 77, 1790-1797. doi: 10.1097/01.tp.0000131150.76841.75

Sanders, L. M., Giudice, L., and Raffin, T. A. (1993). Ethics of fetal tissue transplantation. West J. Med. 159, 400-407.

Sato, M., Asazuma, T., Ishihara, M., Ishihara, M., Kikuchi, T., Kikuchi, M., et al. (2003). An experimental study of the regeneration of the intervertebral disc with an allograft of cultured annulus fibrosus cells using a tissue-engineering method. Spine. 28, 548-553. doi: 10.1097/01.BRS.0000049909.09102.60

Savitz, S. I., Dinsmore, J. H., Wechsler, L. R., Rosenbaum, D. M., and Caplan, L. R. (2004). Cell therapy for stroke. NeuroRx 1, 406-414. doi: 10.1602/neurorx.1.4. 406

Schäfer, R., Knauf, U., Zweyer, M., Högemeier, O., de Guarrini, F., Liu, X., et al. (2006). Age dependence of the human skeletal muscle stem cell in forming muscle tissue. Artif. Organs. 30, 130-140. doi: 10.1111/j.1525-1594.2006. 00199.x

Schantz, J. T., Hutmacher, D. W., Chim, H., Ng, K. W., Lim, T. C., and Teoh, S. H. (2002). Induction of ectopic bone formation by using human periosteal cells in combination with a novel scaffold technology. Cell Transpl. 11, 125-138. doi: 10.0000/096020198389852

Seaberg, R. M., and van der Kooy, D. (2003). Stem and progenitor cells: The premature desertion of rigorous definitions. Trends Neurosci. 26, 125-131. doi: 10.1016/S0166-2236(03)00031-6 
Shah, M., Foreman, D. M., and Ferguson, M. W. (1994). Neutralising antibody to TGF-beta 1,2 reduces cutaneous scarring in adult rodents. J. Cell Sci. 107(Pt5), 1137-1157.

Sharma, P., and Maffulli, N. (2005). Tendon injury and tendinopathy: Healing and repair. J. Bone Joint Surg. Am. 87, 187-202. doi: 10.2106/JBJS.D.01850

Shaw, M. T., and MacKnight, W. J. (2005). Introduction to polymer viscoelasticity, 3rd Edn. New Jersey: Wiley. doi: 10.1002/0471741833

Shea, L. D., Wang, D., Franceschi, R. T., and Mooney, D. J. (2000). Engineered bone development from a pre-osteoblast cell line on three-dimensional scaffolds. Tissue Eng. 6, 605-617. doi: 10.1089/10763270050199550

Sicari, B. M., Rubin, J. P., Dearth, C. L., Wolf, M. T., Ambrosio, F., Boninger, M., et al. (2014). An acellular biologic scaffold promotes skeletal muscle formation in mice and humans with volumetric muscle loss. Sci. Transl. Med. 6, 234-258. doi: $10.1126 /$ scitranslmed.3008085

Skuk, D., and Tremblay, J. P. (2000). Progress in myoblast transplantation: A potential treatment of dystrophies. Microsc. Res. Tech. 48, 213-222. doi: 10. 1002/(SICI)1097-0029(20000201/15)48:3/4<213::AID-JEMT9<3.0.CO;2-Z

Smythe, G. M., Hodgetts, S. I., and Grounds, M. D. (2000). Immunobiology and the future of myoblast transfer therapy. Mol. Ther. 1, 304-313. doi: 10.1006/mthe. 2000.0049

Solchaga, L. A., Tognana, E., Penick, K., Baskaran, H., Goldberg, V. M., Caplan, A. I., et al. (2006). A rapid seeding technique for the assembly of large cell/scaffold composite constructs. Tissue Eng. 12, 1851-1863. doi: 10.1089/ten. 2006.12.1851

Spiekstra, S. W., Breetveld, M., Rustemeyer, T., Scheper, R., and Gibbs, S. (2007). Wound-healing factors secreted by epidermal keratinocytes and dermal fibroblasts in skin substitutes. Wound Repair Regen. 15, 708-717. doi: 10.1111/ j.1524-475X.2007.00280.x

Steinwachs, M. R., Waibl, B., Wopperer, S., and Mumme, M. (2014). Matrixassociated chondroplasty: A novel platelet-rich plasma and concentrated nucleated bone marrow cell-enhanced cartilage restoration technique. Arthrosc. Tech. 3, 279-e282. doi: 10.1016/j.eats.2014.01.002

Stokes, D. G., Liu, G., Coimbra, I. B., Piera-Velazquez, S., Crowl, R. M., and Jiménez, S. A. (2002). Assessment of the gene expression profile of differentiated and dedifferentiated human fetal chondrocytes by microarray analysis. Arthr. Rheum. 46, 404-419. doi: 10.1002/art.10106

Stolzing, A., Jones, E., McGonagle, D., and Scutt, A. (2008). Age-related changes in human bone marrow-derived mesenchymal stem cells: Consequences for cell therapies. Mech. Age. Dev. 129, 163-173. doi: 10.1016/j.mad.2007.12.002

Streit, M., and Braathen, L. R. (2000). Apligraf-a living human skin equivalent for the treatment of chronic wounds. Int. J. Artif. Organs. 23, 831-833. doi: 10.1177/039139880002301208

Strong, D. M., Friedlaender, G. E., Tomford, W. W., Springfield, D. S., Shives, T. C., Burchardt, H., et al. (1996). Immunologic responses in human recipients of osseous and osteochondral allografts. Clin. Orthop. Relat. Res. 326, 107-114. doi: 10.1097/00003086-199605000-00013

Studer, D., Cavalli, E., Formica, F. A., Kuhn, G. A., Salzmann, G., Mumme, M., et al. (2017). Human chondroprogenitors in alginate-collagen hybrid scaffolds produce stable cartilage in vivo. J. Tissue Eng. Regen. Med. 11, 3014-3026. doi: $10.1002 /$ term.2203

Swiss Federal Statistical Office (2019). The Swiss Federal Statistical Office, Neuchâtel: Swiss Federal Statistical Office.

Tambara, K., Sakakibara, Y., Sakaguchi, G., Lu, F., Premaratne, G. U., Lin, X., et al. (2003). Transplanted skeletal myoblasts can fully replace the infarcted myocardium when they survive in the host in large numbers. Circulation 108(Suppl. 1), II259-II263. doi: 10.1161/01.cir.0000087430.17 543.b8

Tan, K. K. B., Salgado, G., Connolly, J. E., Chan, J. K. Y., and Lane, E. B. (2014). Characterization of fetal keratinocytes, showing enhanced stem cell-like properties: A potential source of cells for skin reconstruction. Stem Cell Rep. 3, 324-338. doi: 10.1016/j.stemcr.2014.06.005

Taylor, S. E., Vaughan-Thomas, A., Clements, D. N., Pinchbeck, G., Macrory, L. C., Smith, R. K., et al. (2009). Gene expression markers of tendon fibroblasts in normal and diseased tissue compared to monolayer and three-dimensional culture systems. BMC Muscul. Disord. 10:27. doi: 10.1186/1471-2474-10-27

Tenorio, D. M., Scaletta, C., Jaccoud, S., Hirt-Burri, N., Pioletti, D. P., Jaques, B., et al. (2011). Human fetal bone cells in delivery systems for bone engineering. J. Tissue Eng. Regen. Med. 5, 806-814. doi: 10.1002/term.381
Terraciano, V., Hwang, N., Moroni, L., Park, H. B., Zhang, Z., Mizrahi, J., et al. (2007). Differential response of adult and embryonic mesenchymal progenitor cells to mechanical compression in hydrogels. Stem Cells 25, 2730-2738. doi: 10.1634/stemcells.2007-0228

Thevenot, P., Nair, A., Dey, J., Yang, J., and Tang, L. (2008). Method to analyze three-dimensional cell distribution and infiltration in degradable scaffolds. Tissue Eng. Part C. Methods. Biochem. Biophys. Res. Commun. 377, 458-462. doi: 10.1016/j.bbrc.2008.09.154

Thorpe, S. D., Buckley, C. T., Vinardell, T., O’Brien, F. J., Campbell, V. A., and Kelly, D. J. (2008). Dynamic compression can inhibit chondrogenesis of mesenchymal stem cells. Biochem. Biophys. Res. Commun. 14, 319-331. doi: 10.1089/ten.tec.2008.0221

Tompkins, M., Adkisson, H. D., and Bonner, K. F. (2013). De novo NT allograft. Operat. Techn. Sports Med. 21, 82-89. doi: 10.1053/j.otsm.2013.03.005

Torres-Torrillas, M., Rubio, M., Damia, E., Cuervo, B., Del Romero, A., Peláez, P., et al. (2019). Adipose-Derived Mesenchymal Stem Cells: A promising tool in the treatment of musculoskeletal diseases. Int. J. Mol. Sci. 20:3105. doi: 10.3390/ijms20123105

Touraine, J. L., Roncarolo, M. G., Bacchetta, R., Raudrant, D., Rebaud, A., and Laplace, S. (1993). Fetal liver transplantation: biology and clinical results. Bone Marrow. Transpl. 11(Suppl. 1), 119-122.

Triplett, R. G., and Schow, S. R. (1996). Autologous bone grafts and endosseous implants: Complementary techniques. J. Oral Maxillofac. Surg. 54, 486-494. doi: 10.1016/s0278-2391(96)90126-3

Tsujisaki, M., Igarashi, M., Sakaguchi, K., Eisinger, M., Herlyn, M., and Ferrone, S. (1987). Immunochemical and functional analysis of HLA class II antigens induced by recombinant immune interferon on normal epidermal melanocytes. J. Immunol. 138, 1310-1316.

Tuncali, D., Yavuz, N., Terzioglu, A., and Aslan, G. (2005). The rate of upperextremity deep-structure injuries through small penetrating lacerations. Ann. Plast Surg. 55, 146-148. doi: 10.1097/01.sap.0000168884.88016.e1

Urban, J. P., and Roberts, S. (2003). Degeneration of the intervertebral disc. Arthr. Res. Ther. 5, 120-130. doi: 10.1186/ar629

Vacanti, C. A., Bonassar, L. J., Vacanti, M. P., and Shufflebarger, J. (2001). Replacement of an avulsed phalanx with tissue-engineered bone. N. Engl. J. Med. 344, 1511-1514. doi: 10.1056/NEJM200105173442004

Vacanti, J. P., and Langer, R. (1999). Tissue engineering: The design and fabrication of living replacement devices for surgical reconstruction and transplantation. Lancet 354(Suppl. 1), SI32-SI34. doi: 10.1016/s0140-6736(99)90247-7

Valentin, J. E., Badylak, J. S., McCabe, G. P., and Badylak, S. F. (2006). Extracellular matrix bioscaffolds for orthopaedic applications. A comparative histologic study. J. Bone Joint Surg. Am. 88, 2673-2686. doi: 10.2106/JBJS.E.01008

Valerio, I. L., Sabino, J. M., and Dearth, C. L. (2016). Plastic surgery challenges in war wounded II: Regenerative medicine. Adv. Wound 5, 412-419. doi: 10.1089/ wound.2015.0655

Varkey, M., Ding, J., and Tredget, E. E. (2015). Advances in skin substitutespotential of tissue engineered skin for facilitating anti-fibrotic healing. J. Funct. Biomater. 6, 547-563. doi: 10.3390/jfb6030547

Verdan, C. E. (1972). Half a century of flexor-tendon surgery. Current status and changing philosophies. J. Bone Joint Surg. Am. 54, 472-491. doi: 10.2106/ 00004623-197254030-00003

Vertelov, G., Kharazi, L., Muralidhar, M. G., Sanati, G., Tankovich, T., and Kharazi, A. (2013). High targeted migration of human mesenchymal stem cells grown in hypoxia is associated with enhanced activation of RhoA. Stem Cell Res. Ther. 4:5. doi: 10.1186/scrt153

Vinardell, T., Sheehy, E. J., Buckley, C. T., and Kelly, D. J. (2012). A comparison of the functionality and in vivo phenotypic stability of cartilaginous tissues engineered from different stem cell sources. Tissue Eng. Part A. 18, 1161-1170. doi: 10.1089/ten.TEA.2011.0544

Voleti, P. B., Buckley, M. R., and Soslowsky, L. J. (2012). Tendon healing: Repair and regeneration. Annu. Rev. Biomed. Eng. 14, 47-71. doi: 10.1146/annurevbioeng-071811-150122

Vrahas, M. S., Mithoefer, K., and Joseph, D. (2004). The long-term effects of articular impaction. Clin. Orthop. Relat. Res. 423, 40-43. doi: 10.1097/01.blo. 0000133567.28491.7d

Vuadens, F., Crettaz, D., Scelatta, C., Servis, C., Quadroni, M., Bienvenut, W. V., et al. (2003). Plasticity of protein expression during culture of fetal skin cells. Electrophoresis 24, 1281-1291. doi: 10.1002/elps.200390165 
Wakitani, S., Nawata, M., Tensho, K., Okabe, T., Machida, H., and Ohgushi, H. (2007). Repair of articular cartilage defects in the patello-femoral joint with autologous bone marrow mesenchymal cell transplantation: Three case reports involving nine defects in five knees. J. Tissue Eng. Regen. Med. 1, 74-79. doi: 10.1002/term. 8

Wan, X. Y., Xu, L. Y., Li, B., Sun, Q. H., Ji, Q. L., Huang, D. D., et al. (2018). Chemical conversion of human lung fibroblasts into neuronal cells. Int. J. Mol. Med. 41, 1463-1468. doi: 10.3892/ijmm.2018.3375

Wehbé, M. A. (1992). Tendon graft donor sites. J. Hand Surg. Am. 17, 1130-1132. doi: 10.1016/s0363-5023(09)91079-6

Weinand, C., Pomerantseva, I., Neville, C. M., Gupta, R., Weinberg, E., Madisch, I., et al. (2006). Hydrogel-beta-TCP scaffolds and stem cells for tissue engineering bone. Bone 38, 555-563. doi: 10.1016/j.bone.2005.10.016

Wendt, D., Marsano, A., Jakob, M., Heberer, M., and Martin, I. (2003). Oscillating perfusion of cell suspensions through three-dimensional scaffolds enhances cell seeding efficiency and uniformity. Biotechnol. Bioeng. 84, 205-214. doi: 10.1002/bit.10759

Werner, S., Krieg, T., and Smola, H. (2007). Keratinocyte-fibroblast interactions in wound healing. J. Invest. Dermatol. 127, 998-1008. doi: 10.1038/sj.jid.5700786

Wojtowicz, A. M., Oliveira, S., Carlson, M. W., Zawadzka, A., Rousseau, C. F., and Baksh, D. (2014). The importance of both fibroblasts and keratinocytes in a bilayered living cellular construct used in wound healing. Wound Repair Regen. 22, 246-255. doi: 10.1111/wrr.12154

Wood, F. M., Kolybaba, M. L., and Allen, P. (2006). The use of cultured epithelial autograft in the treatment of major burn wounds: Eleven years of clinical experience. Burns 32, 538-544. doi: 10.1016/j.burns.2006.02.025

World Medical Association. (2013). Declaration of Helsinki: Ethical principles for medical research involving human subjects. JAMA 310, 2191-2194. doi: 10.1001/jama.2013.281053

Wu, C. H., Chang, G. Y., Chang, W. C., Hsu, C. T., and Chen, R. S. (2003). Wound healing effects of porcine placental extracts on rats with thermal injury. Br. J. Dermatol. 148, 236-245. doi: 10.1046/j.1365-2133.2003.05164.x

Xu, W., Wang, Y., Liu, E., Sun, Y., Luo, Z., Xu, Z., et al. (2013). Human iPSCderived neural crest stem cells promote tendon repair in a rat patellar tendon window defect model. Tissue Eng. Part A. 19, 2439-2451. doi: 10.1089/ten.TEA. 2012.0453

Yildirim, M., Spiekermann, H., Biesterfeld, S., and Edelhoff, D. (2000). Maxillary sinus augmentation using xenogenic bone substitute material Bio-Oss ${ }^{\circledR}$ in combination with venous blood. A histologic and histomorphometric study in humans. Clin. Oral. Implants Res. 11, 217-229. doi: 10.1034/j.1600-0501.2000. 011003217.x

Yoshioka, T., Mishima, H., Ohyabu, Y., Sakai, S., Akaogi, H., Ishii, T., et al. (2007). Repair of large osteochondral defects with allogeneic cartilaginous aggregates formed from bone marrow-derived cells using RWV bioreactor. J. Orthop. Res. 25, 1291-1298. doi: 10.1002/jor.20426

Younger, E. M., and Chapman, M. W. (1989). Morbidity at bone graft donor sites. J. Orthop. Trauma. 3, 192-195. doi: 10.1097/00005131-198909000-00002

Zaulyanov, L., and Kirsner, R. S. (2007). A review of a bi-layered living cell treatment (Apligraf ${ }^{\circledR}$ ) in the treatment of venous leg ulcers and diabetic foot ulcers. Clin. Interv. Aging. 2, 93-98. doi: 10.2147/ciia.2007.2.1.93

Zernik, J., Twarog, K., and Upholt, W. B. (1990). Regulation of alkaline phosphatase and alpha 2(I) procollagen synthesis during early intramembranous bone formation in the rat mandible. Differentiation 44, 207-215. doi: 10.1111/j.1432-0436.1990.tb00619.x

Zhang, K., Na, T., Wang, L., Gao, Q., Yin, W., Wang, J., et al. (2014). Human diploid MRC-5 cells exhibit several critical properties of human umbilical cord-derived mesenchymal stem cells. Vaccine 32, 6820-6827. doi: 10.1016/j.vaccine.2014. 07.071

Zhao, R. C. (2020). Stem cell-based therapy for coronavirus disease. Stem Cells Dev. 29, 679-681. doi: 10.1089/scd.2020.0071

Zimmerman, R. K. (2004). Ethical analyses of vaccines grown in human cell strains derived from abortion: Arguments and Internet search. Vaccine 22, 4238-4244. doi: 10.1016/j.vaccine.2004.04.034

Zimmermann, P., Boeuf, S., Dickhut, A., Boehmer, S., Olek, S., and Richter, W. (2008). Correlation of COL10A1 induction during chondrogenesis of mesenchymal stem cells with demethylation of two CpG sites in the COL10A1 promoter. Arthr. Rheum. 58, 2743-2753. doi: 10.1002/art.23736

Zuliani, T., Saiagh, S., Knol, A. C., Esbelin, J., and Dréno, B. (2013). Fetal fibroblasts and keratinocytes with immunosuppressive properties for allogeneic cell-based wound therapy. PLoS One. 8:e70408. doi: 10.1371/journal.pone.007 0408

Conflict of Interest: AL was employed by companies Tec-Pharma SA and LAM Biotechnologies SA.

The remaining authors declare that the research was conducted in the absence of any commercial or financial relationships that could be construed as a potential conflict of interest.

Copyright (c) 2020 Laurent, Hirt-Burri, Scaletta, Michetti, de Buys Roessingh, Raffoul and Applegate. This is an open-access article distributed under the terms of the Creative Commons Attribution License (CC BY). The use, distribution or reproduction in other forums is permitted, provided the original author(s) and the copyright owner(s) are credited and that the original publication in this journal is cited, in accordance with accepted academic practice. No use, distribution or reproduction is permitted which does not comply with these terms. 